\title{
AVALIAÇÃO E CARACTERIZAÇÃO DA DISPONIBILIDADE DO BORO E ZINCO CONTIDOS EM FERTILIZANTES
}

\section{FABIO VALE}

Tese apresentada à Escola Superior de Agricultura "Luiz de Queiroz", Universidade de São Paulo, para obtenção do título de Doutor em Agronomia, Área de Concentração: Solos e Nutrição de Plantas.

PIRACICABA

Estado de São Paulo - Brasil

Novembro - 2000 


\title{
AVALIAÇÃO E CARACTERIZAÇÃO DA DISPONIBILIDADE DO BORO E ZINCO CONTIDOS EM FERTILIZANTES
}

\author{
FABIO VALE \\ Engenheiro Agrônomo
}

Orientador : Prof. Dr. JOSÉ CARLOS ALCARDE

\begin{abstract}
Tese apresentada à Escola Superior de Agricultura “Luiz de Queiróz”, Universidade de São Paulo, para obtenção do título de Doutor em Agronomia, Área de Concentração: Solos e Nutrição de Plantas.
\end{abstract}

\author{
PIRACICABA \\ Estado de São Paulo - Brasil
}

Novembro - 2000 
Dados Internacionais de Catalogação na Publicação (CIP)

DIVISÃO DE BIBLIOTECA E DOCUMENTAÇÃO - Campus "Luiz de Queiroz"/USP

\author{
Vale, Fábio \\ Avaliação e caracterização da disponibilidade do boro e zinco contidos \\ em fertilizantes / Fábio Vale. - - Piracicaba, 2001. \\ 91 p. : il. \\ Tese (doutorado) - Escola Superior de Agricultura Luiz de Queiroz, 2001. \\ Bibliografia. \\ 1. Boro 2. Extrato químico 3. Fertilizante 4. Micronutriente 5. Nutrição e \\ crescimento vegetal 6. Planta 7. Propriedade físico-química 8. Química do solo \\ 9. Zinco I. Título
}

CDD 631.8

\title{
"Permitida a cópia total ou parcial deste documento, desde que citada a fonte - O autor"
}


A meus pais Dario e Ana Maria

Pelo que sou.

DEDICO

À minha esposa Nélvia,

pelo carinho e compreensão.

Às minhas queridas filhas Júlia e Luísa.

Com todo o meu amor!

OFEREÇO 


\section{AGRADECIMENTOS}

À Escola Superior de Agricultura Luiz de Queiroz - ESALQ/USP.

À Fundação de Amparo à Pesquisa do Estado de São Paulo - FAPESP, pela bolsa de doutorado oferecida e pelo auxílio financeiro ao projeto.

Ao Prof. Dr. José Carlos Alcarde, pela orientação, estímulo e amizade.

Ao Conselho do Curso de Pós-Graduação em Solos e Nutrição de Plantas, Professores Francisco Antonio Monteiro, Luis Reynaldo Ferracciú Alleoni e Álvaro Pires da Silva.

Aos Prof. Dr. Godofredo César Vitti e Luís Ignácio Prochnow, pela oportunidade de auxiliá-los no plano PAE, muito importante para minha formação.

Ao Cássio Hamilton Abreu Júnior pelas sugestões apresentadas e pela amizade

Aos funcionários do Departamento de Química da ESALQ, em especial à Rita, Aline e Carlos, pelo auxílio na condução do trabalho.

Ao colega Marcelo E. Alves, pelas sugestões e amizade.

A todos os amigos do setor de Química: Aderbal, Cristiano, Fábio Prata, Tadeu, Adriana, Fernando, Edna, Genelício, pelo convívio durante esses cinco anos.

A outras pessoas que participaram de alguma maneira da realização deste trabalho. 


\section{SUMÁRIO}

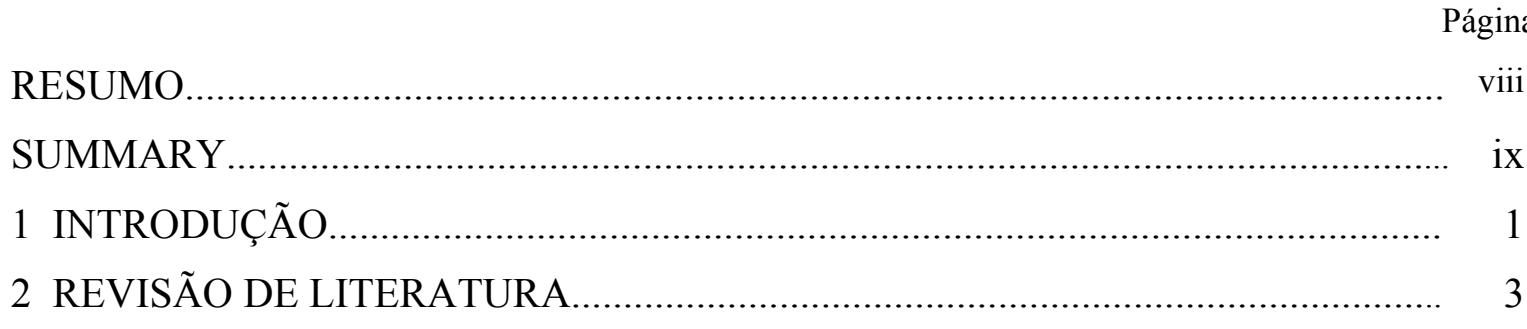

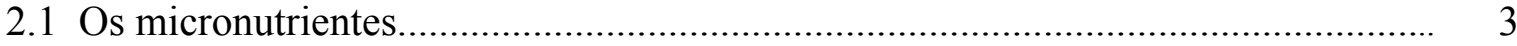

2.2 A Legislação Brasileira de Fertilizantes e os micronutrientes.................................. 5

2.3 Disponibilidade dos micronutrientes contidos nos fertilizantes............................. 7

2.4 Resíduos industriais como fonte de micronutrientes......................................... 12

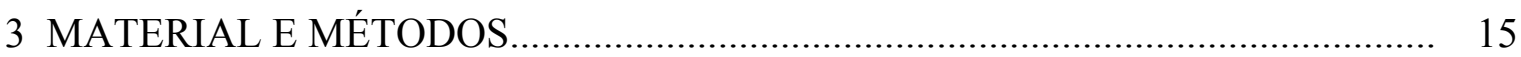

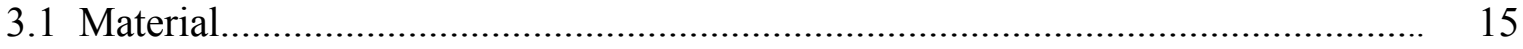

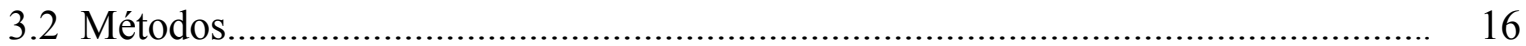

3.2.1 Avaliação da solubilidade do boro e zinco contidos nos materiais fertilizantes..... 16

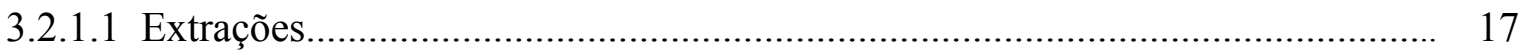

3.2.1.1.1 Teor total de micronutrientes - (Brasil, 1983)......................................... 17

3.2.1.1.2 Teor de micronutrientes solúvel em água....................................................... 17

3.2.1.1.3 Solubilização por agitação - teores de micronutrientes solúveis em solução de ácido cítrico a $20 \mathrm{~g} \mathrm{~L}^{-1}$, em solução neutra de citrato de amônio $(1+9)$, e em solução de DTPA $0,005 \mathrm{~mol} \mathrm{~L}^{-1}$.

3.2.1.1.4 Solubilização por fervura - teores de micronutrientes solúveis em solução de ácido cítrico a $20 \mathrm{~g} \mathrm{~L}^{-1}$, em solução neutra de citrato de amônio $(1+9)$. Teor de boro solúvel em água quente

3.2.1.2 Determinações.

3.2.1.3 Avaliações estatísticas.

3.2.2 Efeito das fontes e doses de boro e zinco para as plantas................................... 20

3.2.2.1 Boro

3.2.2.2 Zinco. 22

3.2.3 Avaliação da disponibilidade do boro e zinco contidos nos materiais fertilizantes 4 RESULTADOS E DISCUSSÃO. 
4.1 Avaliação da solubilidade do boro e zinco contidos nos materiais fertilizantes........ 25

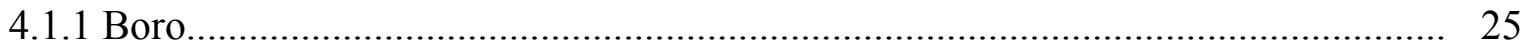

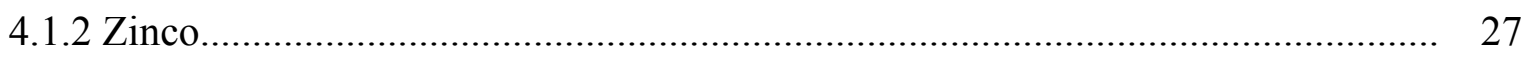

4.2 Efeito das fontes e doses de boro e zinco para as plantas...................................... 29

4.2.1 Efeito das fontes e doses de boro para a cultura da soja..................................... 29

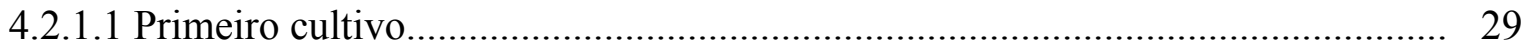

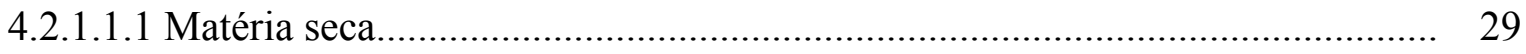

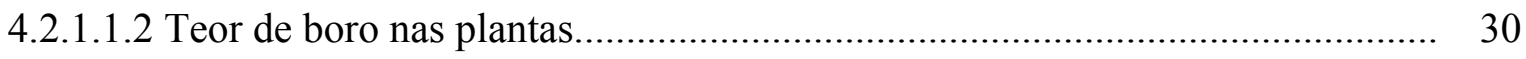

4.2.1.1.3 Conteúdo de boro nas plantas.............................................................................................. 33

4.2.1.2 Teor de boro residual no solo................................................................... 35

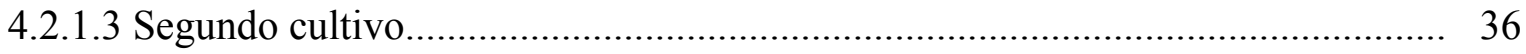

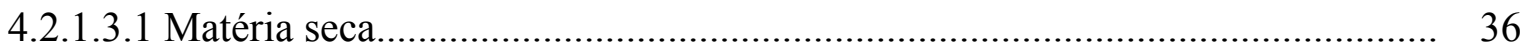

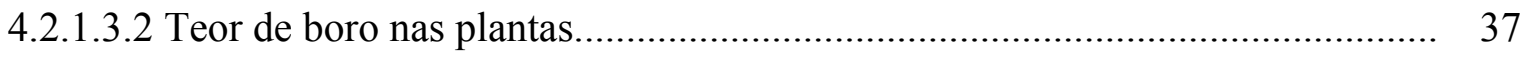

4.2.1.3.3 Conteúdo de boro nas plantas............................................................................................. 39

4.2.2 Efeito das fontes e doses de zinco para a cultura do arroz................................. 41

4.2.2.1 Primeiro cultivo ................................................................................................................ 41

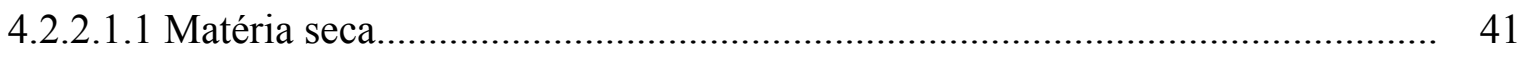

4.2.2.1.2 Teor de zinco nas plantas...................................................................... 42

4.2.2.1.3 Conteúdo de zinco nas plantas.............................................................................................. 45

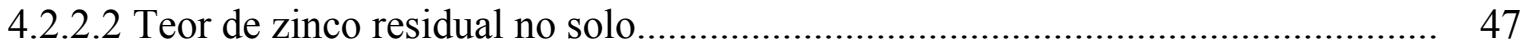

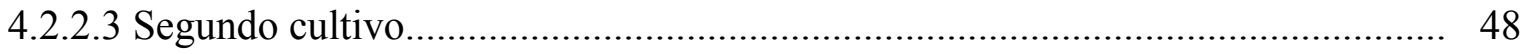

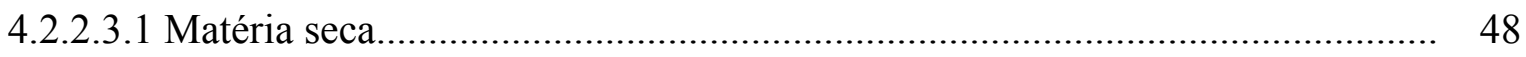

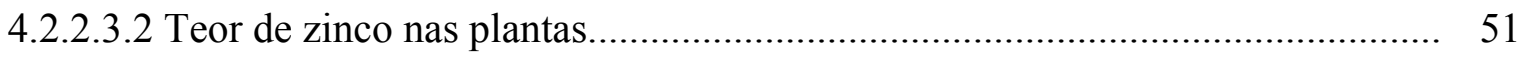

4.2.2.3.3 Conteúdo de zinco nas plantas.......................................................................................... 53

4.2.3 Efeito das fontes e doses de zinco para a cultura do milho................................. 57

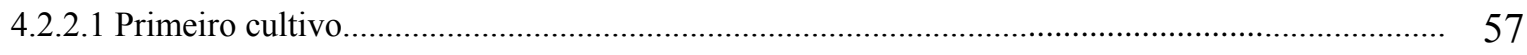

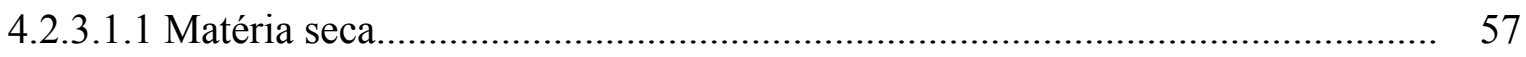

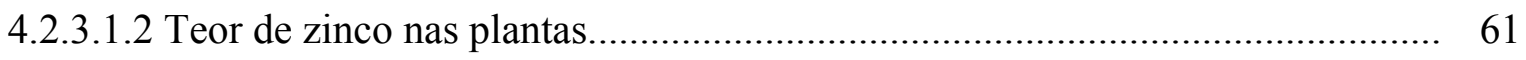

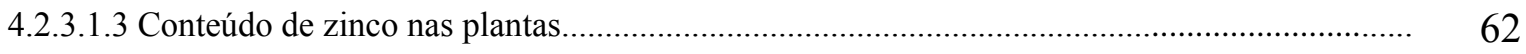

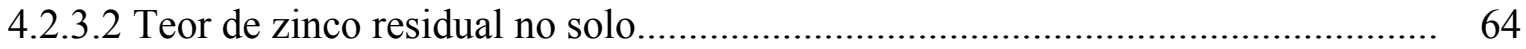

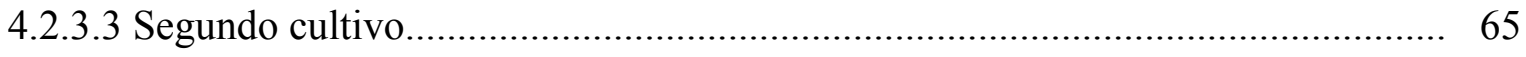




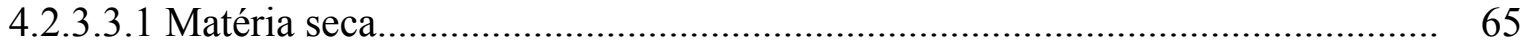

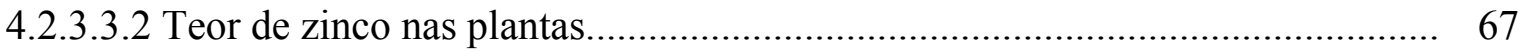

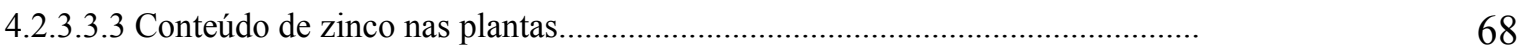

4.3 Avaliação da disponibilidade do boro e zinco contidos nos fertilizantes..................

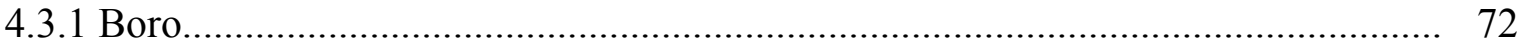

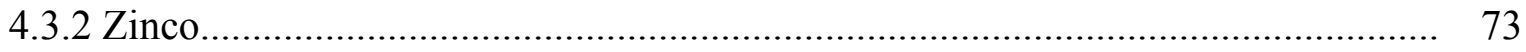

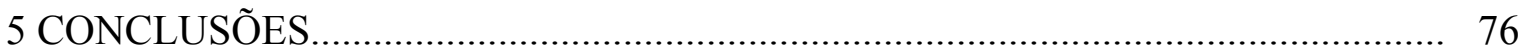

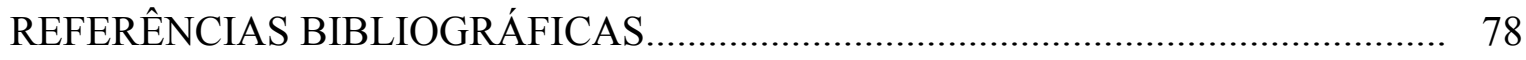

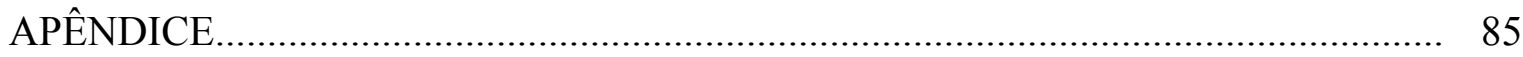




\title{
AVALIAÇÃO E CARACTERIZAÇÃO DA DISPONIBILIDADE DO BORO E ZINCO CONTIDOS EM FERTILIZANTES
}

\author{
Autor: Fabio Vale \\ Orientador: Prof. Dr. José Carlos Alcarde
}

\section{RESUMO}

A legislação brasileira de fertilizantes define que os micronutrientes sejam garantidos pelo seu total presente. Isto permite a utilização de produtos não considerados como fontes de micronutrientes na fabricação dos fertilizantes, como, por exemplo, subprodutos industriais, porém com eficiência agronômica ainda não devidamente comprovada.

O objetivo deste trabalho foi caracterizar a solubilidade do boro e do zinco contidos em fertilizantes, utilizando extratores químicos, e correlacionar com a disponibilidade desses elementos para plantas, procurando identificar o extrator que melhor avalie essa disponibilidade.

A disponibilidade do boro avaliada por plantas testes de soja, foi a mesma em todos os produtos. Os resultados mostraram que tanto a garantia pelo teor total quanto pelo teor solúvel em soluções de ácido cítrico $20 \mathrm{~g} \mathrm{~L}^{-1}$ ou de citrato neutro de amônio $(1+9)$, foram bons para indicar a disponibilidade deste micronutriente em todos os fertilizantes.

O extrator citrato neutro de amônio (1+9), na relação 1:100 e com fervura por cinco minutos, apresentou uma satisfatória correlação com a absorção pelas plantas. Sua adoção contribuirá para o aumento da eficiência das adubações com zinco e também fortalecer a idoneidade de setor de fertilizantes, em especial o de micronutrientes. 


\title{
EVALUATION AND CHARACTERIZATION OF BORON AND ZINC AVAILABILITY FROM FERTILIZERS
}

\author{
Author: Fabio Vale \\ Adviser: Prof. Dr. José Carlos Alcarde
}

\section{SUMMARY}

The Brazilian fertilizer legislation only defines that micronutrients must be guaranteed by their total amount. This has allowed the use of by-products as source of micronutrients for fertilizers, which agronomic efficiencies are still doubtful.

The purpose of this work was to characterize the solubility of boron and zinc

from fertilizers through water, $20 \mathrm{~g} \mathrm{~L}^{-1}$ citric acid, neutral ammonium citrate $(1+9)$ and DTPA extractant solutions. Correlation between solubilities of micronutrients in the fertilizers and their contents in test plants were tried in order to identify the extractor that showed the best evaluation of micronutrient availability on fertilizers for plants.

Boron availability for soybean was the same in all fertilizers. The results showed that both solubility in citric acid or neutral ammonium citrate and total amount of boron was a good indication of this micronutrient availability in all fertilizers.

The neutral ammonium citrate $(1+9)$, relationship 1:100 and boiling for five minutes showed to be a good extractor to identify zinc availability for plants. Your adoption will contribute to improve fertilizations and strengthening of the industry of fertilizers with micronutrients. 


\section{INTRODUÇÃO}

A população mundial vem apresentando aumento muito grande ao longo do anos. Estimativas indicam que a população do nosso planeta será, no ano de 2025, aproximadamente 50\% maior do que a atual, mostrando a grande necessidade de se aumentar a produção de alimentos nessa mesma escala. Por isso, é grande o desfio pelo qual passarão todos os profissionais envolvidos com o meio agrícola em geral.

Estudos mundiais citam o Brasil como um dos poucos locais possíveis de se buscar esse aumento, pois ainda possui muitas áreas aptas à agricultura e, também, por realizar uma agricultura com produtividades possíveis de serem incrementadas. A FAO propõe ao Brasil a necessidade de se dobrar a produção de grãos já no ano 2000, atingindo 140 milhões de toneladas.

Devido à conhecida importância dos fertilizantes na produtividade agrícola, bem como pela significância da participação desses insumos no custo de produção, torna-se imprescindível a avaliação das características e dos fatores responsáveis pelo desempenho desses produtos, a fim de maximizar a sua eficiência agronômica. Nesse sentido, destaca-se o perfeito conhecimento da natureza e composição química do produto para o suprimento adequado das necessidades nutricionais das culturas. Também o controle de qualidade durante a fabricação dos fertilizantes, muitas vezes esquecida, deve ser constante e rigorosa, para que a garantia dos produtos favoreça o agricultor.

Uma preocupação atual com a qualidade dos fertilizantes contendo micronutrientes é relativa a origem da matéria-prima utilizada na fabricação desses produtos: resíduos industriais. Esses produtos possuem micronutrientes em formas pouco assimiláveis pelas plantas, e com elevados teores de metais pesados, de 
comportamento ainda pouco conhecido no ambiente e com grande potencial de contaminação dos solos, plantas e lençóis de água. O método oficial de análise dos fertilizantes, ao exigir a garantia dos micronutrientes pelo teor total, contemporiza o uso desses resíduos. Mas fica a dúvida quanto a disponibilidade e aproveitamento desses micronutrientes pelas plantas. Até que ponto o teor total dos elementos nos fertilizantes é importante? E uma pergunta pode ser feita: produtos feitos com materiais que não são oficialmente considerados como fertilizantes simples pela legislação brasileira, podem ser chamados de fertilizantes?

O objetivo do presente trabalho foi o de caracterizar a solubilidade do boro e zinco contidos em fertilizantes comerciais, através do uso de extratores químicos, e correlacionar com a disponibilidade desses elementos para as plantas, procurando identificar o extrator que melhor avalie essa disponibilidade, em condições de casa-devegetação. 


\section{REVISÃO DE LITERATURA}

\subsection{Os micronutrientes}

Atualmente, sete elementos químicos absorvidos pelas plantas em pequena quantidade satisfazem os três critérios de essencialidade propostos por Arnon \& Stout (1939), sendo, portanto, considerados essenciais para o seu desenvolvimento: boro (B), cloro $(\mathrm{Cl})$, cobre $(\mathrm{Cu})$, ferro $(\mathrm{Fe})$, manganês $(\mathrm{Mn})$, molibdênio $(\mathrm{Mo})$ e zinco $(\mathrm{Zn})$. Existem alguns autores que consideram o cobalto $(\mathrm{Co})$ e o níquel $(\mathrm{Ni})$ como essenciais. À medida em que vão se desenvolvendo novas técnicas analíticas, é provável que esta lista seja aumentada, com a inclusão de novos elementos.

Esses sete micronutrientes têm comportamento químico muito diferenciado. Dois são não-metais (boro e cloro) e os demais são metais pesados. O boro forma sempre ligações covalentes e em condições naturais ocorre como ácido bórico. O cloro é sempre monovalente. $\mathrm{O}$ cobre ocorre como sulfetos, que se intemperizam, liberando o íon $\mathrm{Cu}^{2+} \mathrm{e}$ seus complexos. $\mathrm{O}$ ferro ocorre em óxidos, silicatos e sulfetos e as valências são $2+$ e $3+$. O manganês ocorre em silicatos e óxidos, em valências $2+, 3+$ e $4+$, sendo o $\mathrm{Mn}^{2+}$ mais importante em soluções ácidas. O molibdênio é, dos micronutrientes, o único metal de caráter aniônico em solos e minerais, ocorrendo também como sulfetos. $\mathrm{O}$ zinco ocorre

como sulfetos e silicatos e, no intemperismo de minerais, transforma-se em $\mathrm{Zn}^{2+}$ (Raij, 1991b).

O zinco é um elemento essencial para a síntese do triptofano, que, por sua vez, é o precursor do ácido indol acético. Este ácido é um dos responsáveis pelo aumento do volume celular, além de ter outras funções. As plantas deficientes em zinco mostram grande diminuição no nível de ácido ribonucléico (RNA), do que resulta diminuição na 
síntese de proteína e dificuldade para a divisão celular. Ao que parece, isso ocorre por que o zinco controla, inibindo parcialmente, a atividade da RNAase, que hidrolisa o RNA (Malavolta, 1980). Sintomas de deficiência podem aparecer nas culturas do arroz, milho, citrus e café, entre outras.

Souza et al. (1998) citam que os problemas com Zn têm surgido mais recentemente, em face da incorporação ao processo produtivo de áreas de fertilidade marginal e, ainda, em decorrência do esgotamento gradativo de alguns solos em áreas de cultivo tradicional, onde não existia a reposição desse micronutriente. Dessa maneira, vários trabalhos conduzidos em casa de vegetação e campo, demonstraram que a adição desse micronutriente promove incrementos significativos na produção de milho (Souza et al., 1985; Ritchey et al., 1986; Coutinho et al., 1992b; Galrão, 1995). Também para a cultura do arroz de sequeiro vários resultados semelhantes foram encontrados (Barbosa Filho et al., 1990; Coutinho et al. 1992a).

O boro é o único dos micronutrientes que ainda não preenche o critério direto de essencialidade, porém sabe-se que ele tem participação muito importante no transporte de carboidratos, entre outras funções. Deficiências do elemento afetam com maior intensidade a cultura do café, seguida pelo cítrus e olerícolas, entre outras (Malavolta, 1980).

Buzetti et al. (1990a) citam que em solos de cerrado, sintomas de carência de boro têm surgido na cultura da soja, devido as sucessivas colheitas da cultura na região e ao baixo teor de matéria orgânica dos solos, principal fonte do elemento. Encontraram que o boro aplicado influenciou a produção de matéria seca da parte aérea. O nível crítico do elemento no solo foi de $0,18 \mathrm{mg} \mathrm{dm}^{-3}$ de boro para a matéria seca da parte aérea e $0,23 \mathrm{mg} \mathrm{dm}^{-3}$ para produção de grãos (níveis solúveis em água quente).

No Brasil, segundo Lopes (1984), alguns aspectos justificam a preocupação com os micronutrientes: cultivos intensivos com alta tecnologia em solos que anteriormente possuíam alta fertilidade natural e hoje estão empobrecidos; incorporação de solos com baixa fertilidade ao processo produtivo, como os de cerrado; aumento na produção e uso de fertilizantes de alta concentração, com menores quantidades de micronutrientes como 
impurezas; maior utilização de calcários nos solos, que contribui para a insolubilizacão de vários micronutrientes.

O quadro aponta, então, para um agravamento geral das deficiências de micronutrientes, tornando-se, hoje em dia, uma obrigatoriedade as análises de plantas e solos, para posteriores reposições dos elementos que estarão em falta para o processo produtivo.

\subsection{A Legislação Brasileira de Fertilizantes e os micronutrientes}

A legislação brasileira de fertilizantes e corretivos (Brasil, 1982) é um conjunto de leis, decretos, portarias, ofícios circulares e instruções normativas que dispõem sobre a produção e o comércio de fertilizantes, corretivos e inoculantes, determinando o que é obrigatório, proibido, permitido e facultado. A atual legislação teve início com a Lei 6.894/80, sendo depois alterada pela Lei 6.934/81, instituindo a base de normas que devem ser obedecidas para a Inspeção e Fiscalização da Produção e do Comércio de Fertilizantes, Corretivos, Inoculantes, Estimulantes ou Biofertilizantes.

Essa legislação define quais produtos são considerados como fontes de micronutrientes possíveis de serem utilizados na agricultura. Destes, alguns são solúveis em água, como os quelatos, sulfatos, cloretos e nitratos, enquanto outros são insolúveis, mas disponíveis às plantas quando aplicadas no solo: é o caso dos carbonatos, fosfatos, óxidos, "fritas", dentre outras. Na Tabela 1 estão listados os produtos reconhecidos como fertilizantes e suas respectivas garantias mínimas exigidas pelo Ministério da Agricultura (Brasil, 1982).

O termo "fritas", de acordo com Malavolta (1981) é uma tradução literal do inglês "frited trace elements" (F.T.E.). Os micronutrientes, juntamente com sílica, são fundidos à $1300{ }^{\mathrm{O}} \mathrm{C}$; ao sair do forno o produto é resfriado rapidamente em água, gerando cristais borossilicatados, que, em seguida, são moídos muito finamente. Porém Alcarde \& Vale (1999), ao caracterizarem os micronutrientes contidos em fertilizantes, 
Tabela 1 - Garantias mínimas de teores de micronutrientes em adubos exigidas pelo Ministério da Agricultura (Brasil, 1982)

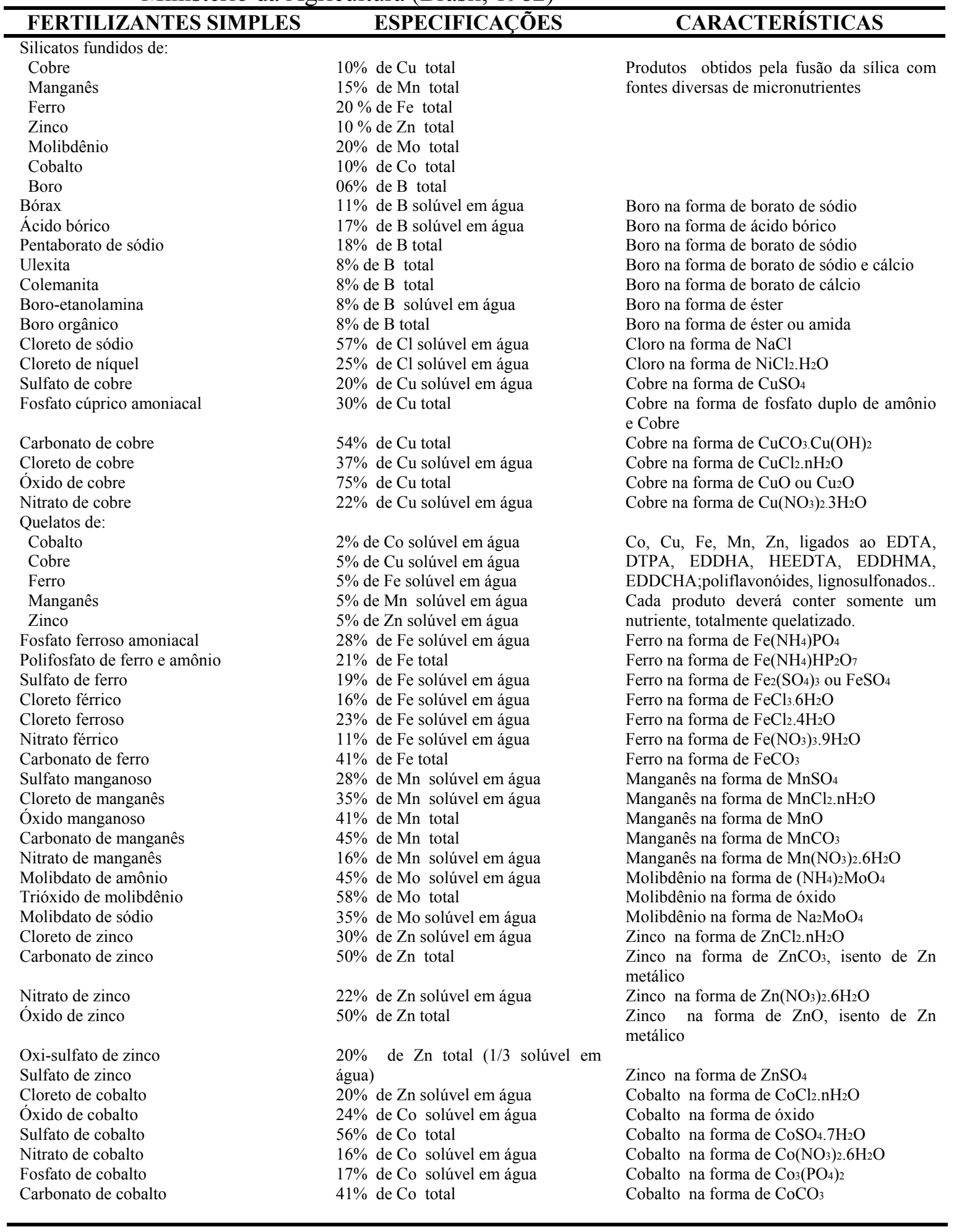


concluíram que, em relação as "fritas" comercializadas no Brasil, estas não são realmente fritas, isto é, os micronutrientes não estão fundidos com silicatos, que é uma característica do produto; são somente uma mistura de micronutrientes ${ }^{(*)}$. Esses mesmos autores encontraram nesses produtos teores elevados de elementos metálicos que não estão garantidos pelos fabricantes, principalmente ferro, além de cádmio, níquel e chumbo, considerados como metais pesados tóxicos, sendo, então, indícios de utilização de resíduos industriais como fonte dos micronutrientes metálicos para a produção dos fertilizantes.

\subsection{Disponibilidade dos micronutrientes contidos nos fertilizantes}

A legislação brasileira especifica algumas características para cada produto, bem como a garantia mínima de micronutrientes em cada um (Tabela 1), (Brasil,1982). Alcarde \& Rodella (1993) alertam que esta legislação abre um precedente que pode estar sendo usado na produção de fertilizantes: a garantia e os métodos oficiais de análise (Brasil,1983) referem-se ao teor total dos micronutrientes. Isto abre oportunidade de se comercializar diversos subprodutos industriais que contenham micronutrientes, com teores totais mínimos exigidos pela legislação, mas com esses elementos não estando nas formas químicas com que se rotulam e previstas na legislação. Um exemplo, onde este artifício pode ser usado, é a comercialização de zinco metálico sob o rótulo de óxido de zinco. Essas formas químicas não contempladas na legislação como fonte de micronutrientes, como o zinco metálico, silicato de zinco e sulfeto de zinco, são de eficiência agrícola ainda duvidosa e, além disso, podem ter teores elevados de contaminantes que, com o passar do tempo, podem ser grandes poluentes dos solos, podendo afetar a colheita e a qualidade dos produtos. Por exemplo, na formulação 0414-08 + 0,5\% de Zn a legislação não exige qualquer caracterização da forma com que o zinco se encontra: considera-se o teor total e analisa-se como tal.

Nos métodos de determinação de micronutrientes da AOAC - American Official Analytical Chemistry (Kane, 1995) são apresentados, além dos métodos para

\footnotetext{
${ }^{(*)}$ Esta é a razão pela qual o termo "fritas" é utilizado entre aspas: não corresponde ao conceito clássico
} 
determinação do teor total dos micronutrientes nos fertilizantes, procedimentos para determinação de Fe e Zn solúveis em água e em EDTA a 2,5\%, e de Mn solúvel em água e em ácido, neste caso discriminando $\mathrm{Mn}^{2+}$ e $\mathrm{Mn}^{4+}$. A metodologia japonesa (Japão, 1982), por outro lado, apresenta procedimentos para determinação de teores solúveis em água de $\mathrm{Mo}, \mathrm{Cu}, \mathrm{Fe}, \mathrm{Hg}, \mathrm{Mn}, \mathrm{Cr}, \mathrm{Zn}, \mathrm{Cd}$ e $\mathrm{Pb}$. Inclui ainda método para extração de Mn em ácido cítrico $20 \mathrm{~g} \mathrm{~L}^{-1}$ e relação 1:150 entre fertilizante e extrator..

A água é considerada o extrator universal. Sua extração é indicação da presença de elementos altamente solúveis, prontamente disponíveis, seja em solos ou fertilizantes. Pode-se considerar a solubilidade em água como o "teor nobre" de um elemento contido em um produto.

Alcarde \& Ponchio (1979) esclareceram a ação solubilizante dos extratores usados na determinação do fósforo solúvel dos fertilizantes. A solução neutra de citrato de amônio (CNA) é uma solução tampão relativamente concentrada, de pH 7,0, surgida em 1871, enquanto a solução de ácido cítrico (AC) é mais diluída, mas com acidez elevada, isto é, pH 2,30, surgida em 1899. Demostraram, com base nas constantes de estabilidade do ânion citrato, a habilidade que o CNA, no $\mathrm{pH}$ neutro, e o $\mathrm{AC}$, em condições de acidez, têm em formar complexos com cátions presentes, e passíveis de serem disponíveis, entre eles o $\mathrm{Ca}, \mathrm{Cu}, \mathrm{Fe}, \mathrm{Mg}, \mathrm{Mn}, \mathrm{Na}$ e $\mathrm{Zn}$. Fica clara a capacidade dos dois extratores em solubilizar os micronutrientes metálicos. Em contrapartida, são liberados para a solução, também, os ânions acompanhantes, como os fosfatos, sulfatos, molibdatos e boratos. Os autores citam também, que as características físico-químicas como estrutura cristalina, grau de pureza e porosidade dos fertilizantes são de grande importância, na solubilização.

Agentes quelantes mostraram-se promissores na avaliação da disponibilidade de micronutrientes catiônicos no solo. Esses agentes combinam-se com os metais livres em solução, formando complexos solúveis, e reduzem a atividade do metal livre na solução. Em resposta, metais são dessorvidos, se desligando da fase sólida para reabastecer os metais livres na solução, até atingir o equilíbrio. A quantidade de metais que se acumula na solução durante a extração é função tanto da atividade do íon metálico, como da habilidade do solo em repor esses íons. Lindsay \& Norvell (1978) utilizaram o ácido 
dietilenopentacético (DTPA) como extrator de $\mathrm{Cu}, \mathrm{Fe}, \mathrm{Mn}$ e $\mathrm{Zn}$ dos solos. Escolheram a solução de DTPA a $\mathrm{pH}=7,30$ por ser a que apresenta a mais favorável combinação de constantes de estabilidade para complexações simultâneas dos micronutrientes metálicos. De acordo com esses autores, neste $\mathrm{pH}$ há a maior habilidade do DTPA em complexar $\mathrm{Cu}, \mathrm{Fe}, \mathrm{Mn}$ e $\mathrm{Zn}$, em competição com o cálcio e magnésio. É de se esperar que, de forma semelhante ao que ocorre com o AC e CNA, com a adaptação do uso de agentes quelantes na análise de disponibilidade de micronutrientes em fertilizantes, quando ocorrer complexação de $\mathrm{Cu}, \mathrm{Fe}, \mathrm{Mn}$ e $\mathrm{Zn}$, e também de $\mathrm{Ca}, \mathrm{Mg}$ e $\mathrm{Na}$, se estes estiverem presentes, ocorrerá também a solubilização de ânions fosfato, borato e molibdato presentes.

Arnon (1975) cita que o sulfeto de zinco, produto não reconhecido como micronutriente pela Legislação Brasileira de Fertilizantes, foi menos eficiente que o sulfato e óxido de zinco em várias culturas.

Alguns autores estudaram os efeitos de micronutrientes na produção de culturas. Os principais resultados encontrados referem-se ao elemento zinco. Barbosa Filho et al. (1982), comparando o efeito das fontes sulfato, cloreto e óxido de zinco, com duas fritas comerciais, concluíram que não houve diferença significativa entre as três primeiras fontes empregadas. Mas quando essas foram comparadas com as fritas, elas se mostraram mais eficientes quanto à produção de grãos de arroz. Decaro et al. (1983), avaliando os efeitos da fontes sulfato e óxido de zinco na cultura do milho, constataram não ter sido possível detectar-se efeito significativo entre as fontes, embora o sulfato de zinco tenha revelado ligeira tendência de ser melhor que o óxido. A análise econômica dos resultados obtidos revelou que o ótimo econômico para o caso do sulfato de zinco situou-se na faixa de 5-10 $\mathrm{kg} \mathrm{ha}^{-1}$ de $\mathrm{Zn}$, enquanto para o óxido essa faixa foi um pouco superior, $10-15 \mathrm{~kg} \mathrm{ha}^{-1}$ de $\mathrm{Zn}$. Esses resultados evidenciam a maior disponibilidade do elemento oriundo do sulfato.

Malavolta et al. (1987) estudaram o efeito das fontes sulfato de zinco, óxido de zinco e uma "frita" comercial na cultura do milho. As maiores produções de matéria seca foram obtidas com as fontes sulfato de zinco na dose de $0,5 \mathrm{mg} \mathrm{dm}^{-3}$, e óxido de zinco e "frita" $1,0 \mathrm{mg} \mathrm{dm}^{-3}$. Os tratamentos com sulfato de zinco nas doses 1,0 e 1,5 mg 
$\mathrm{dm}^{-3}$ causaram diminuição na produção de matéria seca, que é explicado como possível toxidez do elemento às plantas. Outra conclusão foi de que o teor de $\mathrm{Zn}$ residual no solo (DTPA e Mehlich) devido ao óxido e à frita foi aproximadamente a metade do deixado pelo sulfato. Esses resultados mostram que o $\mathrm{Zn}$ contido no sulfato se mostrou mais disponível às plantas do que aquele contido nas outras fontes.

Mortvedt (1992) avaliou a disponibilidade do Zn contido em diferentes produtos, com solubilidade em água variando de 0 a $100 \%$ do teor total. Todos os produtos foram testados sob a forma moída e granulada. Concluiu que a disponibilidade do elemento nos produtos moídos foi semelhante, independente da solubilidade em água. No caso dos produtos granulados, encontrou que à medida que se aumentava a solubilidade em água do fertilizante, maior era a produção de matéria seca e a absorção de Zn pelas plantas que receberam esses produtos. Recomendou que um fertilizante granulado deve conter um mínimo de $40 \%$ de Zn solúvel em água, para se ter boa resposta das culturas. A aplicação de micronutrientes sob forma granulada vem sendo bastante utilizada atualmente, por facilitar a aplicação dos produtos. Porém, isto tem comprometido a distribuição homogênea dos micronutrientes, devido à pequena quantidade que é aplicada nas adubações.

Amrani et al. (1999) avaliaram a produção de matéria seca de milho em função da aplicação de sulfato e oxissulfatos de zinco com diferentes solubilidades em água. Os fertilizantes foram aplicados sob a forma física na qual foram coletados, granulados. Concluíram que o teor total de zinco não foi suficiente para determinar a disponibilidade do elemento; porém a solubilidade em água é um importante fator. Assumindo-se que doses de 5 a $10 \mathrm{~kg} \mathrm{ha}^{-1}$ de $\mathrm{Zn}$ são normalmente recomendadas para boa produtividade, os autores sugerem que em torno de $50 \%$ do $\mathrm{Zn}$ contido nos fertilizantes seja solúvel em água, visando o suprimento adequado do elemento para as culturas.

Goos et al. (2000) compararam a disponibilidade do zinco contido em um sulfato de zinco granulado, um humato-lignosulfonato de zinco granulado (ZnHL) e ZnEDTA líquido, para a cultura do milho. As duas fontes granuladas foram aplicadas no solo, diretamente como eram, e também na forma moída. Todas as fontes de zinco forneceram excelente resposta quanto à produção de matéria seca quando aplicadas sob a 
forma pó; porém a disponibilidade do elemento contido na fonte sulfato granulado foi quase zero. Também para o ZnHL a disponibilidade da forma moída foi melhor que a granulada. Os autores sugerem que as diferenças entre essas fontes dependem muito mais das características físicas que das características químicas dos produtos.

Alcarde \& Rodella (1993) objetivaram estabelecer um procedimento analítico, viável de utilização em rotina, que permitisse reconhecer se um material contendo zinco pode ou não ser considerado fertilizante simples. Os materiais testados foram zinco metálico pulverizado, óxido de zinco em pó, quatro amostras de óxido de zinco comercial de diversas procedências, carbonato de zinco comercial, duas amostras de sulfeto de zinco, sendo uma comercial e uma como subproduto de metalurgia, cinco amostras de silicato de zinco comercial de diferentes procedências, e três misturas de zinco metálico com óxido de zinco. O estudo baseou-se no uso das soluções extratoras: cloreto de amônio nas concentrações de 2; 1,5 e $1 \mathrm{~mol} \mathrm{~L}^{-1}$, citrato de amônio de densidade 1,09 e pH=7,0, isto é, a mesma solução usada na avaliação do fósforo, na concentração original e nas diluições $(1+1),(1+3)$ e (1+9), e solução de ácido cítrico a $20 \mathrm{~g} \mathrm{~L}^{-1}$, relação 1:100. As técnicas de extração foram agitação ou fervura da amostra com as soluções extratoras. Os resultados mostraram que a fervura da amostra com a solução de citrato de amônio na diluição (1+9) foi a que melhor caracterizou os fertilizantes simples contendo zinco insolúvel em água. Outra constatação foi que os produtos não fertilizantes contendo zinco insolúvel em água existentes no mercado apresentaram teores elevados de cobre, chumbo e cádmio.

Vale \& Alcarde (1999) desenvolveram um trabalho cujo objetivo foi o de identificar a solubilidade dos micronutrientes em fertilizantes comerciais, através do uso de extratores químicos, correlacionando-a com a disponibilidade às plantas. Avaliaram 30 amostras de fertilizantes comerciais diferentes, sendo selecionados produtos considerados de solubilidade lenta, como as "fritas" e alguns boratos, além de produtos mais solúveis, como os sais e quelatos para aplicação foliar, em que, teoricamente, todo o micronutriente está prontamente disponível. Todos os produtos foram analisados quanto ao teor total de micronutrientes, teores solúveis em água, e em soluções de ácido cítrico $20 \mathrm{~g} \mathrm{~L}^{-1}$ (AC), de citrato neutro de amônio na diluição $1+9$ (CNA), de ácido 
dietilenopentacético (DTPA) 0,005 $\mathrm{mol} \mathrm{L}^{-1}$ e de ácido etilenodiaminotetracético (EDTA) $0,005 \mathrm{~mol} \mathrm{~L}^{-1}$. A técnica de extração foi agitação da amostra com o extrator por 1 hora, na relação 1:100. Posteriormente, realizaram uma avaliação do aproveitamento dos micronutrientes por plantas de arroz, utilizando-se do método de Neubauer \& Schneider (Catani \& Bergamin Filho, 1961). As correlações entre os teores de cada micronutriente solubilizados pelos diferentes extratores e os teores encontrados nas plantas indicaram o ácido cítrico como um extrator promissor para caracterizar a disponibilidade de cobre, ferro, manganês e zinco contidos nos fertilizantes, enquanto que para o boro o teor total se mostrou condizente com a disponibilidade do elemento. A garantia dos micronutrientes catiônicos pelo teor total, conforme exige a legislação, não indicou a real disponibilidade dos mesmos nos fertilizantes, mostrando-se necessária a definição de extratores para esse fim.

\subsection{Resíduos industriais como fonte de micronutrientes}

A utilização de resíduos industriais como matéria prima para a produção de fertilizantes é prática importante, sobretudo quando se pensa na necessidade de eliminação destes produtos do ambiente. Porém, é necessário que se faça a caracterização correta desses resíduos, a fim de se evitar possíveis contaminações, e que também se tenha correto aproveitamento dos nutrientes contidos nos mesmos.

O emprego de resíduos industriais como fontes mais baratas de micronutrientes é relatado por Nikitin (1960), o qual menciona a matéria-prima e os processos usuais de obtenção: rejeito de cobre metálico e óxido de zinco que são lixiviados por ácido sulfúrico, convertendo-se nos sulfatos respectivos; o manganês pode ser recuperado a partir de escórias de altos fornos; sulfato ferroso é obtido quando o ferro ou o aço são mergulhados em ácido sulfúrico na limpeza preparatória para a galvanização. Certamente esses produtos obtidos são solúveis, pois há um tratamento do resíduo antes de utilizá-lo como fonte de micronutrientes. O problema maior é a utilização dos resíduos como tal, na forma metálica, diretamente na adubação, pois os micronutrientes provavelmente não estarão disponíveis. 
Mortvedt \& Cunningham (1971) descrevem que o óxido de zinco e o sulfato de manganês podem ser obtidos como subprodutos da fabricação de $\mathrm{Na}_{2} \mathrm{~S}_{2} \mathrm{O}_{4}$ e $\mathrm{Na}_{2} \mathrm{~S}_{2} \mathrm{O}_{3}$ respectivamente, ou produção de outros materiais. Mencionam que alguns desses subprodutos podem também conter quantidades apreciáveis de metais pesados, como o chumbo, não se sabendo se no caso de serem aplicados ao solo teriam algum efeito sobre as plantas.

De acordo com Mortvedt (1985), muitos subprodutos industriais contendo micronutrientes são comercializados nos E.U.A.. A maior parte desses é comercializada como fontes de $\mathrm{Mn}$ ou de $\mathrm{Zn}$. São fontes de $\mathrm{Zn}$ geradas como subproduto: ácidos usados na indústria de galvanização e outros; pós recuperados de chaminés ou de armazéns de ensacamento; resíduos de fundição de zinco e de indústrias de pigmentos, baterias, borracha e outras. Para o autor, a lixiviação é necessária para remover impurezas desses produtos, mas alguns deles são usados sem purificação. Alguns ácidos usados também contém ferro, que pode ser precipitado como sulfeto ferroso $\left(\mathrm{FeSO}_{4}\right)$. Ainda segundo Mortvedt (1985), alguns dos subprodutos industriais podem conter também metais pesados como contaminantes, como cádmio, crômio, níquel e chumbo em concentrações muito variáveis, porém como geralmente as doses de micronutrientes usadas são baixas, a adição do metal pesado será ainda menor.

Os resíduos ou subprodutos contendo micronutrientes estão disponíveis em vários países, de acordo com Lopes (1991). Por exemplo, pneus contém uma alta porcentagem de óxido de zinco. Se os pneus descartados fossem queimados, as cinzas poderiam apresentar uma alta percentagem do elemento. As aparas de metal, escórias, resíduos de indústria de galvanoplastia, baterias são também fontes em potencial. Vários processos são usados para remover impurezas desses materiais, mas alguns produtos contendo óxido de zinco $(\mathrm{ZnO})$ são usados sem purificação. Cita, também, que subprodutos de cloretos, nitratos, sulfatos e oxissulfatos de Zn, e sulfatos e oxissulfatos de Mn são também comercializados como fonte de micronutrientes. Comenta sobre o problema de contaminações com metais pesados, mas não considera nada sobre disponibilidade. 
A preocupação da empresa Produquímica, produtora de fertilizantes com micronutrientes, em razão da polêmica causada com a importação de um material para ser usado como fonte de micronutrientes para fertilizantes, fez gerar um trabalho de autoria de Malavolta (1994). Nele, o autor faz uma avaliação sobre o potencial de uso desse material. O resíduo apresentava a seguinte constituição: 44,9\% de $\mathrm{Zn}, 8,2 \%$ de $\mathrm{Cu}$, $0,16 \%$ de $\mathrm{Fe}, 0,69 \%$ de $\mathrm{Mn}$, além de metais pesados tóxicos em baixas concentrações. Se o resíduo fosse usado diretamente para fornecer $\mathrm{Zn}$, teria de ser usado para fornecer uma dose de aproximadamente $5 \mathrm{~kg}$ por hectare, isto é, dever-se-ia aplicar inicialmente $11 \mathrm{~kg}$ do produto por hectare, a cada dois anos, devido ao efeito residual. Discute também que jamais ocorrerão prejuízos ao ambiente nesta dose, mas não comenta nada sobre necessidade de tratamento do resíduo para que os micronutrientes fiquem disponíveis às plantas.

Amaral Sobr ${ }^{\circ}$ (1993) estudou a eficiência de um resíduo siderúrgico como corretivo e fonte de $\mathrm{Cu}, \mathrm{Fe}, \mathrm{Mn}$, Ni e $\mathrm{Zn}$. Na análise do solo, os teores de Fe, Mn, Ni e $\mathrm{Zn}$ aumentaram, e o de $\mathrm{Cu}$ sofreu decréscimo. Houve correlação, positiva e significativa, somente entre os teores de $\mathrm{Cu}$ e $\mathrm{Ni}$ do solo e as quantidades absorvidas pelo sorgo, o que parece indicar que os demais elementos não estavam sob forma disponível para as plantas.

Amaral (1994), avaliando um resíduo da indústria de zinco, com 2,5 a 3\% de zinco total, como corretivo da acidez e fonte de zinco e metais pesados para plantas de milho e eucalipto, concluiu que, em doses altas o resíduo tem potencial para ser considerado uma fonte de zinco, principalmente para o milho. O grande problema encontrado foi que a aplicação de doses elevadas permitiu a detecção de cádmio no solo e nas plantas de milho, em concentrações acima do limite máximo admitido para a alimentação humana e animal. Para o eucalipto não se encontrou esse problema, porém o problema ocorrido com o milho praticamente inviabilizou o uso geral do produto como fonte de zinco. 


\section{MATERIAL E MÉTODOS}

\subsection{Materiais}

O estudo foi conduzido no Setor de Química do Departamento de Ciências Exatas da Escola Superior de Agricultura "Luiz de Queiroz" - ESALQ, da Universidade de São Paulo.

Foram utilizadas seis amostras de produtos fertilizantes contendo boro, e oito contendo zinco. Na Tabela 2 encontram-se os produtos utilizados e sua respectivas garantias.

Tabela 2. Fontes de B e Zn utilizadas e suas respectivas garantias.

\begin{tabular}{|c|c|c|c|c|}
\hline Amostra & Descrição & Característica & Garantia & Forma física \\
\hline \multicolumn{5}{|c|}{ Boro } \\
\hline 1 & Gran-o-bor 10 & Frita comercial & $10 \%$ & Granulado \\
\hline 2 & Borogran & Frita comercial & $10 \%$ & Granulado \\
\hline 3 & MIB-4 & Frita comercial & $4 \%$ & Granulado \\
\hline 4 & Ácido bórico & P.A. & $16,5 \%$ & Granulado \\
\hline 5 & Ulexita & Borato & $12 \%$ & Farelado \\
\hline 6 & Colemanita & Borato & $12 \%$ & Farelado \\
\hline \multicolumn{5}{|c|}{ Zinco } \\
\hline 1 & Gran-o-zinc 20 & Frita comercial & $20 \%$ & Granulado \\
\hline 2 & Plantzinco F II & Frita comercial & $20 \%$ & Granulado \\
\hline 3 & Zincogran 20 & Frita comercial & $20 \%$ & Granulado \\
\hline 4 & FMM - 100 & Frita comercial & $13,5 \%$ & Pó \\
\hline 5 & Sulfato de zinco & P.A. & $22,7 \%$ & Granulado \\
\hline 6 & Óxido de zinco & P.A. & $80,3 \%$ & Pó \\
\hline 7 & Zinco metálico & P.A. & $100 \%$ & Pó \\
\hline 8 & Resíduo & Resíduo & $(*)$ & Pó \\
\hline
\end{tabular}

(*) Por não ser fertilizante, não tem garantia 
As amostras foram preparadas, visando homogeneização e quarteação em quarteador tipo "Jones" até se atingir, aproximadamente, 100 gramas de fertilizante por amostra. A seguir, as amostras foram moídas manualmente, em gral de porcelana, até que passassem por completo em peneira com abertura de malha de $0,84 \mathrm{~mm}\left(\mathrm{ABNT} \mathrm{n}^{\mathrm{o}}\right.$ 20).

O objetivo de se utilizar alguns produtos de origem P.A. foi o de se ter certeza de que os micronutrientes fornecidos por essas fontes estavam na forma que realmente o nome do produto indicava.

\subsection{Métodos}

\subsubsection{Avaliação da solubilidade do boro e zinco contidos nos materiais fertilizantes}

Todos os produtos foram analisados quanto ao teor total de micronutrientes, aos teores solúveis em água e em soluções de ácido cítrico a $20 \mathrm{~g} \mathrm{~L}^{-1}$, de citrato neutro de amônio na diluição $(1+9)$, e de ácido dietilenopentacético (DTPA) 0,005 mol L-1 . Para o boro, também foi determinada a solubilidade do elemento em água quente. As solubilidades em ácido cítrico e em citrato neutro de amônio foram feitas de duas maneiras diferentes: uma por agitação da amostra com o extrator por uma hora, e a outra por fervura por 5 minutos. A escolha dos extratores utilizados baseou-se no fato da água ser considerado o extrator universal, o ácido cítrico e o citrato neutro de amônio por já serem utilizados na rotina para determinação de fósforo solúvel em fertilizantes, e o DTPA por ser um extrator responsável por quelação e liberação de micronutrientes metálicos em solução, e também por serem utilizados na análise de solos para avaliar os micronutrientes metálicos disponíveis (Lindsay \& Norvell, 1978). Já a água quente é o método de extração que apresenta boa correlação entre teor de B nos solos e quantidade disponível às plantas, sendo bastante utilizado na rotina em alguns laboratórios de análise de solos (Bataglia \& Raij, 1989). Foram realizadas três repetições de análises para cada método e cada produto. 


\subsubsection{Extrações}

\subsection{Teor total de micronutrientes - (Brasil,1983)}

a) Transferiu-se $1,0000 \mathrm{~g}$ da amostra para copo de $250 \mathrm{~mL}$, adicionaram-se $10 \mathrm{~mL}$ de $\mathrm{HCl}$ concentrado, ferveu-se para evaporar até próximo à secura em chapa aquecedora, sem deixar queimar o resíduo;

b) Dissolveu-se o resíduo com $20 \mathrm{~mL}$ de solução de $\mathrm{HCl} 2 \mathrm{~mol} \mathrm{~L}^{-1}$, fervendo ligeiramente. Após, filtrou-se em papel faixa branca, recebendo o filtrado em balão de $100 \mathrm{~mL}$. Lavou-se o copo e o filtro com porções de água destilada e completouse o volume.

c) Foi preparada uma prova em branco.

\subsection{Teor de micronutrientes solúvel em água}

a) Transferiu-se $2,5000 \mathrm{~g}$ da amostra para papel de filtro faixa branca adaptado em funil, e colocado sobre balão de $250 \mathrm{~mL}$;

b) Lavou-se com porções sucessivas de água destilada, tendo o cuidado de promover a suspensão da amostra; procedeu-se a extração até quase completar $250 \mathrm{~mL}$. Nos filtrados que apresentaram turbidez, foram adicionados $2 \mathrm{~mL}$ de solução de $\mathrm{HNO}_{3}$ $(1+1)$;

c) Completou-se o volume.

d) Foi preparada uma prova em branco.

3.2.1.1.3 Solubilização por agitação - teores de micronutrientes solúveis em solução de ácido cítrico a $20 \mathrm{~g} \mathrm{~L}^{-1}$, em solução neutra de citrato de amônio $(1+9)$, e em solução de DTPA $0,005 \mathrm{~mol} \mathrm{~L}^{-1}$

Para todos estas extrações a metodologia utilizada foi a mesma, somente modificando-se o extrator. 
a) Transferiu-se $1,0000 \mathrm{~g}$ da amostra para erlenmeyer de $250 \mathrm{~mL}$, adicionou-se $100 \mathrm{~mL}$ da solução extratora e tampou-se com rolha de borracha;

b) Colocou-se em agitador tipo Wagner e agitou-se por 1 hora, a 30-40 rpm;

c) Filtrou-se em papel faixa branca, recebendo o filtrado em balão de $250 \mathrm{~mL}$. Lavouse o copo e o filtro com porções de água destilada e completou-se o volume.

d) Foi preparada uma prova em branco.

A solução de ácido cítrico a $2 \%$ (AC) foi preparada dissolvendo-se 20,0 g de ácido cítrico cristalizado em água destilada. Transferiu-se para balão volumétrico de $1 \mathrm{~L}$ e completou-se o volume.

A solução neutra de citrato de amônio (1+9) - (CNA) foi preparada dissolvendose $370 \mathrm{~g}$ de ácido cítrico cristalizado em 1,5 L de água destilada e adicionando-se 345 $\mathrm{mL}$ de solução de hidróxido de amônio. Determinou-se o $\mathrm{pH}$ potenciometricamente, ajustando à 7,0 com hidróxido de amônio $(1+7)$. Acertou-se a densidade para 1,09, à temperatura de $20^{\circ} \mathrm{C}$, com água destilada. Em balão volumétrico de $1 \mathrm{~L}$, adicionaram-se $100 \mathrm{~mL}$ dessa solução e completou-se o volume.

A solução de DTPA utilizada foi a mesma proposta por Lindsay \& Norvell (1978) e que é utilizada atualmente para a extração de micronutrientes metálicos disponíveis de solos, pelo princípio da complexação. A única diferença dessa metodologia aqui proposta é a mudança da relação entre a massa da amostra com o extrator. Para solo a relação utilizada é de 1:2, enquanto para fertilizante, por ter uma concentração bem maior de micronutrientes, é proposta a relação 1:100.

O preparo da solução de DTPA $0,005 \mathrm{~mol} \mathrm{~L}^{-1}$ foi feito dissolvendo-se $1,96 \mathrm{~g}$ de DTPA num copo com aproximadamente $200 \mathrm{~mL}$ de água deionizada, acrescentando-se 14,9 $\mathrm{mL}$ de trietanolamina e, em seguida, 1,47 $\mathrm{g}$ de cloreto de cálcio $\left(\mathrm{CaCl}_{2} \cdot 2 \mathrm{H}_{2} \mathrm{O}\right)$. Transferiu-se para balão volumétrico de 1L, e o volume foi completado com água deionizada. $\mathrm{O}$ pH da solução foi corrigido para 7,3 através do uso de ácido clorídrico 4 mol L ${ }^{-1}$. 


\subsection{Solubilização por fervura - teores de micronutrientes solúveis em solução de ácido cítrico a $20 \mathrm{~g} \mathrm{~L}^{-1}$, em solução neutra de citrato de amônio $(1+9)$. Teor de boro solúvel em água quente.}

a) Transferiu-se $1,0000 \mathrm{~g}$ da amostra para copo de $250 \mathrm{~mL}$, adicionou-se $100 \mathrm{~mL}$ da solução extratora e ferveu-se por 5 minutos em chapa aquecedora.

b) Filtrou-se em papel faixa branca, recebendo o filtrado em balão de $250 \mathrm{~mL}$. Lavouse o copo e o filtro com porções de água destilada e completou-se o volume.

c) Foi preparada uma prova em branco.

As soluções extratoras foram preparadas da mesma maneira com indicado no item anterior. No caso da solubilização do boro em água quente, utilizou-se somente de água destilada como extrator.

\subsubsection{Determinações}

A determinação do $\mathrm{B}$ contido em todos os fertilizantes foi feita pelo método colorimétrico de azometina H, segundo metodologia descrita por Silva \& Graner (1996), e a de Zn por espectrofotometria de absorção atômica, todas após convenientes diluições com água destilada.

\subsubsection{Avaliações estatísticas}

Com os resultados obtidos, calculou-se a solubilidade de cada elemento em cada extrator em função do teor total obtido neste trabalho. Através da aplicação do teste de Tukey à $1 \%$, comparou-se a solubilidade do B ou Zn contido em cada fertilizante, em cada extrator. 


\subsubsection{Efeito das fontes e doses de boro e zinco para as plantas}

O presente trabalho foi conduzido em condições de casa-de-vegetação, no Setor de Química do Departamento de Ciências Exatas da ESALQ/USP. Consistiu no cultivo de plantas em um NEOSSOLO QUARTZARÊNICO Órtico típico (Oliveira, 1999), antiga Areia Quartzosa, muito pobre em boro e zinco, visando-se conseguir o máximo aproveitamento do elemento contido nos fertilizantes. Nas Tabelas 3 e 4 encontram-se, respectivamente, as análises química (Raij \& Quaggio, 1983) e física do solo (EMBRAPA, 1997).

Tabela 3 - Análise química do NEOSSOLO utilizada no experimento

\begin{tabular}{|c|c|c|c|c|c|c|c|c|c|c|c|c|c|c|}
\hline $\mathrm{pH}$ & M.O & $\mathrm{P}$ & $\mathrm{S}-\mathrm{SO}_{4}$ & K & $\mathrm{Ca}$ & $\mathrm{Mg}$ & $\mathrm{Al}$ & $\mathrm{H}+\mathrm{Al}$ & SB & $\mathrm{T}$ & $\mathrm{V}$ & $\mathrm{m}$ & B & Zn \\
\hline $\mathrm{CaCl}_{2}$ & $\mathrm{~g} \mathrm{dm}^{-3}$ & & $\mathrm{dm}^{-3}--$ & & & & $\mathrm{mol}_{\mathrm{c}}$ & & & & --'- & ---- & $----m g$ & $m^{-3}-$ \\
\hline 4,4 & 14 & 3 & 4 & 0,5 & 3 & 1 & 4 & 31 & 4,5 & 35,5 & 13 & 47 & $\mathbf{0 , 0 7}$ & 0,1 \\
\hline
\end{tabular}

Tabela 4 - Análise física do NEOSSOLO utilizada no experimento

\begin{tabular}{ccc}
\hline Areia & Silte & Argila \\
\hline 914 & 75 & 11 \\
\hline
\end{tabular}

\subsubsection{Boro}

Utilizaram-se plantas de soja para avaliação da disponibilidade do boro contido nos fertilizantes. Cada parcela constituiu-se de vasos de $4 \mathrm{dm}^{-3}$ de capacidade. O tratamento realizado antes do plantio da soja consistiu na aplicação de calcário dolomítico calcinado ( $\mathrm{PRNT}=110 \%, \mathrm{PN}=119 \%, \mathrm{CaO}=37 \%$ e $\mathrm{MgO}=26 \%$ ) para elevar a saturação por bases a 70\%. Após um mês da aplicação do calcário, foi feita a

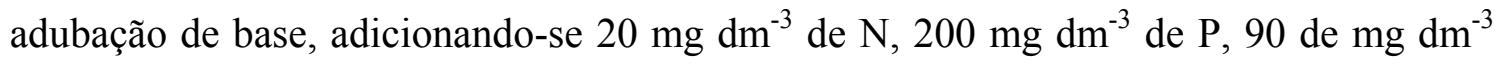
$\mathrm{K}, 90 \mathrm{mg} \mathrm{dm}^{-3} \mathrm{de} \mathrm{Ca}, 30 \mathrm{mg} \mathrm{dm}^{-3}$ de $\mathrm{Mg}, 60 \mathrm{mg} \mathrm{dm}^{-3}$ de S, $4 \mathrm{mg} \mathrm{dm}^{-3}$ de $\mathrm{Cu}, 20 \mathrm{mg}$ $\mathrm{dm}^{-3}$ de Fe, $20 \mathrm{mg} \mathrm{dm}^{-3}$ de $\mathrm{Mn}, 0,4 \mathrm{mg} \mathrm{dm}^{-3}$ de Mo e $4 \mathrm{mg} \mathrm{dm}^{-3}$ de Zn por meio de solução nutritiva. Trinta dias após a germinação foram adicionados $30 \mathrm{mg} \mathrm{dm}^{-3} \mathrm{de} \mathrm{K}$ 
como cobertura. As fontes de boro testadas e suas garantias estão citadas na Tabela 2. As doses utilizadas foram $0,0.5,1 \mathrm{e} 2 \mathrm{mg} \mathrm{dm} \mathrm{de}^{-3} \mathrm{~B}$. Todos os produtos foram adicionados no plantio da cultura, na forma de pó, semelhante ao utilizado nas avaliações da disponibilidade (passadas em peneira com abertura de malha de $0,84 \mathrm{~mm}$ - peneira n⿳⼈ㅡㄴ 20 - ABNT). Essas doses foram aplicadas baseando-se nos teores totais do elemento encontradas neste trabalho. O delineamento experimental adotado foi o inteiramente casualizado, em esquema fatorial $6 \times 4$ (6 fontes e 4 doses), com três repetições. A variedade de soja utilizada foi a BR 37. Após a germinação, deixou-se uma planta por vaso e, diariamente, procedeu-se a irrigação mantendo-se o solo com umidade adequada. Ao final do período experimental (90 dias após o plantio) fez-se o corte das plantas rente ao solo e secou-se o material em estufa, obtendo-se, assim, a matéria seca da parte aérea produzida em cada unidade experimental. Em seguida as amostras foram moídas, submetidas à digestão nítrico-perclórica, e, nos extratos obtidos, procedeu-se as determinações dos teores de B de acordo com Malavolta et al. (1997). Com base na massa de matéria seca produzida e nos teores de B, calculou-se a quantidade absorvida do elemento em cada unidade experimental.

Após a colheita das plantas, peneirou-se o solo remanescente, e retirou-se uma amostra do solo de cada vaso, onde foi determinado o teor de B residual por tratamento, em solução de cloreto de bário a quente (Abreu et al., 1994). Plantou-se novamente soja em cada vaso, sem aplicar as fontes de B, visando-se identificar o efeito residual do elemento para as plantas. Somente foi adicionada a solução nutritiva para fornecer os outros nutrientes. A condução foi semelhante à anterior, e após a colheita determinou-se a quantidade de matéria seca da parte aérea produzida, o teor de $\mathrm{B}$ e a quantidade absorvida do elemento em cada unidade experimental.

Determinou-se, então, através da aplicação de modelos estatísticos adequados, o efeito das doses e fontes do elemento na produção de matéria seca de soja, no teor e conteúdo de boro nas plantas, no boro residual do solo, assim como todos os efeitos no segundo cultivo da cultura. 


\subsubsection{Zinco}

Para avaliação da disponibilidade do $\mathrm{Zn}$ foram realizados dois experimentos, um com a cultura do arroz e outro com a do milho. No experimento com arroz foram testadas seis fontes: gran-o-zinc, plantzinco, zincogran, zinco metálico, óxido de zinco e sulfato de zinco. No experimento com milho, as fontes plantzinco e zinco metálico foram substituídas pelo FMM - 100 e resíduo, totalizando também seis fontes do elemento. O preparo dos experimentos foi semelhante para as duas culturas. Cada parcela constituiu-se de vasos de $4 \mathrm{dm}^{-3}$ de capacidade. Também foi feita a correção da acidez do solo pela aplicação do calcário já citado anteriormente, no cultivo da soja. Após um mês da aplicação do calcário, foi feita a adubação de base, adicionando-se 60 $\mathrm{mg} \mathrm{dm}{ }^{-3}$ de N, $200 \mathrm{mg} \mathrm{dm}^{-3}$ de P, $90 \mathrm{de} \mathrm{mg} \mathrm{dm}^{-3} \mathrm{~K}, 90 \mathrm{mg} \mathrm{dm}^{-3}$ de Ca, $30 \mathrm{mg} \mathrm{dm}^{-3}$ de $\mathrm{Mg}, 60 \mathrm{mg} \mathrm{dm}^{-3}$ de S, $4 \mathrm{mg} \mathrm{dm}^{-3}$ de B, $4 \mathrm{mg} \mathrm{dm}^{-3}$ de Cu, $20 \mathrm{mg} \mathrm{dm}^{-3}$ de Fe, $20 \mathrm{mg} \mathrm{dm}^{-3}$ de $\mathrm{Mn}$ e $0,4 \mathrm{mg} \mathrm{dm}^{-3}$ de Mo, por meio de solução nutritiva. Trinta dias após a germinação foram adicionados $60 \mathrm{mg} \mathrm{dm}^{-3}$ de $\mathrm{N} \mathrm{e} 30 \mathrm{mg} \mathrm{dm}^{-3}$ de $\mathrm{K}$ como cobertura. As doses utilizadas foram $0,1,2 \mathrm{e} 4 \mathrm{mg} \mathrm{\textrm {dm } ^ { - 3 }} \mathrm{de} \mathrm{Zn}$. Todos os produtos foram adicionados no plantio da cultura, na forma de pó, semelhante ao utilizado nas avaliações da disponibilidade (passadas em peneira com abertura de malha de $0,84 \mathrm{~mm}$ - peneira $\mathrm{n}^{\mathrm{o}} 20$ - ABNT). Essas doses foram aplicadas baseando-se nos teores totais do elemento encontradas neste trabalho. $\mathrm{O}$ delineamento experimental adotado foi o inteiramente casualizado, em esquema fatorial $6 \times 4$ ( 6 fontes e 4 doses), com três repetições. A variedade de arroz utilizada foi a IAC 162, enquanto a de milho foi um híbrido Avant (Novartis). Após a germinação, deixou-se, respectivamente, quatro plantas de arroz ou duas de milho por vaso e, diariamente, procedeu-se a irrigação mantendo-se o solo com umidade adequada. Ao final do período experimental (90 dias após o plantio) fez-se o corte das plantas rente ao solo e secou-se o material em estufa na faixa de 60 a $70^{\circ} \mathrm{C}$, obtendo-se, assim, a matéria seca da parte aérea produzida em cada unidade experimental. Em seguida, as amostras foram moídas, submetidas à digestão nítricoperclórica, e, nos extratos obtidos, procedeu-se à determinação dos teores de $\mathrm{Zn}$ de acordo com Malavolta et al.(1997). Com base na massa de matéria seca produzida e 
teores de $\mathrm{Zn}$, calculou-se a quantidade absorvida do elemento em cada unidade experimental.

Após a colheita das plantas, peneirou-se o solo remanescente, e retirou-se uma amostra do solo de cada vaso, onde foi determinado o teor de $\mathrm{Zn}$ residual, em DTPA (Lindsay \& Norvell, 1978). Plantou-se novamente arroz ou milho em cada vaso, sem aplicar as fontes de $\mathrm{Zn}$, visando-se identificar o efeito residual do elemento para as plantas. Somente foi adicionada a solução nutritiva para fornecer os demais nutrientes. A condução foi semelhante à anterior, e, após a colheita determinou-se a quantidade de matéria seca da parte aérea produzida, o teor de $\mathrm{Zn}$ e a quantidade absorvida do elemento em cada unidade experimental.

Determinou-se, então, através da aplicação de modelos estatísticos adequados, o efeito das fontes e doses de zinco na produção de matéria seca de arroz ou milho, no teor e conteúdo do elemento nas plantas, no zinco residual do solo, assim como todos os efeitos no segundo cultivo das culturas.

\subsubsection{Avaliação da disponibilidade do boro e zinco contidos nos materiais fertilizantes}

Esta avaliação foi realizada, para o boro, aplicando-se correlações lineares entre a solubilidade do elemento contido nos fertilizantes, em todos os extratores, com a quantidade acumulada do elemento pelas plantas de soja. O mesmo foi feito para o zinco, correlacionando-se a solubilidade do elemento contido nos produtos, em todos os extratores, com o acumulado pelas culturas de arroz ou milho. Com esses valores, pretendeu-se concluir o trabalho, definindo qual, ou quais extratores, podem ser indicados como os melhores para definir a disponibilidade do boro e do zinco contido em fertilizantes.

Também foi realizada uma comparação entre o conteúdo dos elementos encontrados nas plantas e o Índice de Eficiência das Agronômica das fontes (IEA), em relação à fonte que apresentou maior disponibilidade dos micronutrientes. Calculou-se o IEA através da seguinte expressão: 


$$
\mathrm{IEA}=\frac{\text { Conteúdo }_{\text {fonte } \mathrm{x}}-\text { Conteúdo }_{\text {testemunha }}}{\text { Conteúdo }_{\text {fonte } \mathrm{m}}-\text { Conteúdo }_{\text {testemunha }}}
$$

onde, Conteúdo fonte $\mathrm{x}^{=}$Conteúdo nas plantas em função de cada fonte

Conteúdo $\mathrm{fonte}_{\mathrm{m}}=$ Conteúdo da fonte que apresentou maior disponibilidade

Conteúdo $\mathrm{o}_{\text {testemunha }}=$ Conteúdo nas plantas testemunha 


\section{RESULTADOS E DISCUSSÃO}

\subsection{Avaliação da solubilidade do boro e zinco contidos nos materiais fertilizantes}

\subsubsection{Boro}

$\mathrm{Na}$ Tabela 5 encontram-se os teores de B solubilizados pelos diferentes extratores, em \%, para todas as fontes. Observa-se que, com exceção da fonte MIB-4, todos os produtos apresentaram teores totais do elemento significativamente iguais aos garantidos pelos fabricantes, apesar do Gran-o-bor e Borogran terem apresentado valores um pouco inferiores, e colemanita e ulexita um pouco superiores aos garantidos. Porém a solubilidade nos extratores foi diferenciada para cada produto. Em todos os produtos analisados, a solubilidade em água foi a mais baixa em relação aos outros extratores. A solubilidade em água quente também foi baixa em todos os produtos, comparando com os extratores orgânicos. Nos produtos tipo "fritas" foi observado um efeito diferenciado do extrator na solubilidade do boro, o que não ocorreu com o ácido bórico, como era esperado, pois este produto é reconhecidamente de alta solubilidade em água. A ulexita apresentou uma boa solubilidade nos extratores orgânicos, enquanto que para a colemanita isto só ocorreu pela solubilização pelo AC e CNA sob fervura.

Na Tabela 6 encontram-se as solubilidades de cada fonte de B em relação ao teor total encontrado neste trabalho. Todas as "fritas" apresentaram solubilidade significativamente iguais em cada extrator avaliado, mostrando serem produtos de composição semelhante. A colemanita apresentou resultados de solubilidade inferiores aos apresentados pela ulexita, com exceção dos extratores AC e CNA sob fervura. Isto pode ser explicado pela composição química das duas fontes: a ulexita é um borato de 
sódio e cálcio $\left(\mathrm{Na}_{2} \mathrm{O} \cdot 2 \mathrm{CaO} \cdot 5 \mathrm{~B}_{2} \mathrm{O}_{5} \cdot 16 \mathrm{H}_{2} \mathrm{O}\right)$, portanto mais solúvel em água que a colemanita, um borato de cálcio $\left(\mathrm{CaO} \cdot 3 \mathrm{~B}_{2} \mathrm{O}_{3} \cdot 5 \mathrm{H}_{2} \mathrm{O}\right)$ (Raij, 1991a). Então, somente o $\mathrm{AC}$ e CNA sob fervura conseguiram solubilizar o borato unido ao cálcio. Outra constatação interessante foi de que os extratores $\mathrm{AC}$ sob agitação, e $\mathrm{AC}$ e CNA sob fervura foram estatisticamente semelhantes à solubilização pelo teor total, apesar da solubilidade da colemanita em AC agitação ter sido inferior. Isto indica a possibilidade de substituição da substituição do teor total por um desses extratores sem comprometimento dos resultados.

Tabela 5 - Boro total e solúvel nos diferentes extratores.

\begin{tabular}{lcccccc}
\hline \multirow{2}{*}{ Fonte } & Gran-o-bor & Borogran & MIB - 4 & Ác. Bórico & Ulexita & Colemanita \\
\cline { 2 - 6 } & $10,00 \mathrm{a}$ & $10,00 \mathrm{a}$ & $4,00 \mathrm{a}$ & $16,35 \mathrm{a}$ & $12,00 \mathrm{a}$ & $12,00 \mathrm{ab}$ \\
\hline Garantia & $9,37 \mathrm{ab}$ & $8,29 \mathrm{ab}$ & $2,72 \mathrm{~b}$ & $16,35 \mathrm{a}$ & $12,46 \mathrm{a}$ & $12,36 \mathrm{a}$ \\
Teor total & $3,97 \mathrm{f}$ & $3,41 \mathrm{~d}$ & $1,36 \mathrm{c}$ & $16,07 \mathrm{a}$ & $4,70 \mathrm{c}$ & $1,16 \mathrm{e}$ \\
Água & $6,42 \mathrm{e}$ & $5,64 \mathrm{c}$ & $1,65 \mathrm{c}$ & $16,10 \mathrm{a}$ & $10,72 \mathrm{~b}$ & $6,44 \mathrm{c}$ \\
Água quente & $8,60 \mathrm{bcd}$ & $7,97 \mathrm{ab}$ & $2,47 \mathrm{~b}$ & $16,14 \mathrm{a}$ & $12,40 \mathrm{a}$ & $10,50 \mathrm{~b}$ \\
AC agitação & $9,23 \mathrm{abc}$ & $8,22 \mathrm{ab}$ & $2,64 \mathrm{~b}$ & $16,25 \mathrm{a}$ & $12,28 \mathrm{a}$ & $12,21 \mathrm{a}$ \\
AC fervura & $8,14 \mathrm{~d}$ & $7,40 \mathrm{bc}$ & $2,47 \mathrm{~b}$ & $15,89 \mathrm{a}$ & $12,18 \mathrm{a}$ & $7,22 \mathrm{c}$ \\
CNA agitação & $9,18 \mathrm{bc}$ & $8,13 \mathrm{ab}$ & $2,61 \mathrm{~b}$ & $16,28 \mathrm{a}$ & $12,23 \mathrm{a}$ & $11,82 \mathrm{ab}$ \\
CNA fervura & $8,47 \mathrm{~cd}$ & $7,64 \mathrm{bc}$ & $2,42 \mathrm{~b}$ & $16,30 \mathrm{a}$ & $12,15 \mathrm{a}$ & $4,12 \mathrm{~d}$ \\
DTPA & &
\end{tabular}

Médias seguidas de mesmas letras indicam resultados semelhantes pelo Teste de Tukey à $1 \%$

Comparação nas colunas

Média de três repetições

Tabela 6 - Solubilidade de Boro nos extratores, em \% em relação ao teor total.

\begin{tabular}{lccccccc}
\hline \multicolumn{1}{c}{ Fonte } & Água & $\begin{array}{c}\text { Água } \\
\text { Quente }\end{array}$ & $\begin{array}{c}\text { AC } \\
\text { agitação }\end{array}$ & $\begin{array}{c}\text { AC } \\
\text { fervura }\end{array}$ & $\begin{array}{c}\text { CNA } \\
\text { agitação }\end{array}$ & $\begin{array}{c}\text { CNA } \\
\text { fervura }\end{array}$ & DTPA \\
\hline Gran-o-bor & $42,35 \mathrm{bc}$ & $68,46 \mathrm{abc}$ & $91,71 \mathrm{a}$ & $98,47 \mathrm{a}$ & $86,84 \mathrm{a}$ & $97,90 \mathrm{a}$ & $90,36 \mathrm{bc}$ \\
Borogran & $41,08 \mathrm{bc}$ & $68,01 \mathrm{abc}$ & $96,10 \mathrm{a}$ & $99,09 \mathrm{a}$ & $89,27 \mathrm{a}$ & $98,03 \mathrm{a}$ & $92,08 \mathrm{abc}$ \\
MIB -4 & $49,94 \mathrm{~b}$ & $60,59 \mathrm{bc}$ & $90,58 \mathrm{a}$ & $96,77 \mathrm{a}$ & $90,70 \mathrm{a}$ & $95,84 \mathrm{a}$ & $88,86 \mathrm{c}$ \\
Ác. Bórico & $98,27 \mathrm{a}$ & $98,47 \mathrm{a}$ & $98,70 \mathrm{a}$ & $99,37 \mathrm{a}$ & $97,19 \mathrm{a}$ & $99,59 \mathrm{a}$ & $99,67 \mathrm{a}$ \\
Ulexita & $37,75 \mathrm{c}$ & $86,06 \mathrm{ab}$ & $99,55 \mathrm{a}$ & $98,58 \mathrm{a}$ & $97,75 \mathrm{a}$ & $98,13 \mathrm{a}$ & $97,49 \mathrm{ab}$ \\
Colemanita & $9,36 \mathrm{~d}$ & $52,09 \mathrm{c}$ & $84,95 \mathrm{~b}$ & $98,84 \mathrm{a}$ & $58,43 \mathrm{~b}$ & $95,66 \mathrm{a}$ & $33,34 \mathrm{~d}$ \\
\hline
\end{tabular}

Médias seguidas de mesmas letras indicam resultados semelhantes pelo Teste de Tukey à $1 \%$

Para AC agitação, resultados semelhantes pelo Teste de Tukey à 5\%

Comparação nas colunas

Média de três repetições. 


\subsubsection{Zinco}

Os teores de zinco solubilizados pelos diferentes extratores, para todas as fontes, são apresentados na Tabela 7. Os teores totais encontrados foram semelhantes aos garantidos para todas as fontes, exceto para Plantzinco e FMM-100. A solubilidade em água foi a mais baixa em relação aos outros extratores testados. A solubilidade do zinco contido nas "fritas" variou de maneira semelhante de extrator para extrator, sendo o AC, entre os extratores orgânicos, o de maior capacidade na solubilização do elemento. $\mathrm{O}$ sulfato, como era de se esperar, em decorrência de sua composição química, mostrou uma elevada solubilidade em todos os extratores; porém, a menor solubilidade deste em DTPA, pode indicar a baixa eficiência deste extrator na avaliação da disponibilidade do $\mathrm{Zn}$ em fertilizantes. Interessante também foram os valores encontrados para o óxido de zinco, isto é, solubilidade zero em água, característica do produto, porém solubilidade em AC agitação semelhante ao total, e também alta solubilidade nos dois métodos em que foram utilizados o CNA. Porém a solubilidade em AC fervura foi baixa. É importante salientar que neste método ocorreram problemas analíticos na solubilização do óxido de zinco. Interessantes também são os resultados apresentados pelas fontes metálico e resíduo industrial; porém estes dois produtos apresentavam-se em forma de pó muito fino, e isto pode ter influenciado as análises.

$\mathrm{Na}$ Tabela 8 encontram-se as solubilidades de cada fonte de $\mathrm{Zn}$ em relação ao teor total encontrado neste trabalho. A solubilidade em água foi baixa para todas as fontes, exceto para sulfato. Mortvedt (1992) e Amrani et al. (1999) recomendam que um fertilizante granulado fonte de zinco, bem como três das quatro "fritas" utilizadas no trabalho, devem apresentar uma solubilidade em água de 40 a 50\%. Pode-se antecipar que esses produtos deverão apresentar uma disponibilidade baixa de zinco para as plantas. As "fritas" apresentaram solubilidade nos extratores orgânicos menor que a do óxido e um pouco superior que a do Zn metálico. Entre as "fritas", o FMM-100 apresentou solubilidade inferior em todos os extratores, mostrando ser uma fonte quimicamente diferente das outras três. O resíduo apresentou solubilidade elevada no AC agitação e CNA fervura. As solubilidades em AC agitação e CNA fervura do Zn 
apresentadas pelo sulfato e óxido de zinco mostraram-se condizentes com o aproveitamento por plantas dessas fontes, citado por Barbosa Filho et al. (1982) e Decaro et al. (1983).

Tabela 7 - Zinco total e solúvel nos diferentes extratores.

\begin{tabular}{|c|c|c|c|c|c|c|c|c|}
\hline \multirow{2}{*}{ Fonte } & Gran-o-zinc & Plantzinco & Zincogran & FMM-100 & $\mathrm{ZnSO}_{4}$ & $\mathrm{ZnO}$ & Metálico & Resíduo $^{(1)}$ \\
\hline & \multicolumn{8}{|c|}{ 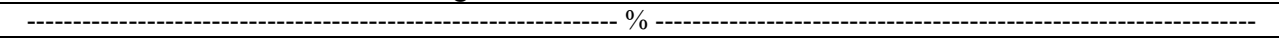 } \\
\hline Garantia & $20,00 \mathrm{a}$ & $20,00 \mathrm{a}$ & $20,00 \mathrm{~b}$ & $13,50 \mathrm{a}$ & $22,73 \mathrm{a}$ & $80,34 \mathrm{a}$ & $100,0 \mathrm{a}$ & - \\
\hline Teor total & $19,53 \mathrm{a}$ & $15,87 \mathrm{~b}$ & $21,85 \mathrm{a}$ & $12,72 \mathrm{~b}$ & $22,69 \mathrm{a}$ & $80,28 \mathrm{a}$ & $99,90 \mathrm{a}$ & $59,13 \mathrm{a}$ \\
\hline Água & $0,79 \mathrm{f}$ & $0,97 \mathrm{~g}$ & $3,18 \mathrm{e}$ & $0,03 \mathrm{~g}$ & $22,66 \mathrm{a}$ & $0,18 \mathrm{f}$ & $0,19 \mathrm{e}$ & $0,70 \mathrm{e}$ \\
\hline AC agitação & $15,00 \mathrm{~b}$ & $12,48 \mathrm{c}$ & $16,88 \mathrm{c}$ & $7,81 \mathrm{c}$ & $22,55 \mathrm{a}$ & $80,04 \mathrm{a}$ & $31,61 \mathrm{~b}$ & $47,60 \mathrm{~b}$ \\
\hline AC fervura & $13,83 \mathrm{c}$ & $10,63 \mathrm{~d}$ & $15,90 \mathrm{c}$ & $7,33 \mathrm{~d}$ & $22,58 \mathrm{a}$ & $35,06 \mathrm{~d}$ & $33,99 \mathrm{~b}$ & $16,16 \mathrm{~d}$ \\
\hline CNA agitação & $10,05 \mathrm{~d}$ & 8,29 e & $11,63 \mathrm{~d}$ & $1,76 \mathrm{f}$ & $22,56 \mathrm{a}$ & $62,40 \mathrm{c}$ & $12,31 \mathrm{c}$ & $31,87 \mathrm{c}$ \\
\hline CNA fervura & $10,13 \mathrm{~d}$ & $8,17 \mathrm{e}$ & $12,03 \mathrm{~d}$ & $4,03 \mathrm{e}$ & $22,60 \mathrm{a}$ & $72,25 \mathrm{~b}$ & $11,23 \mathrm{c}$ & $45,86 \mathrm{~b}$ \\
\hline DTPA & $3,70 \mathrm{e}$ & $4,67 \mathrm{f}$ & $3,82 \mathrm{e}$ & $1,84 \mathrm{f}$ & $17,75 \mathrm{~b}$ & $5,12 \mathrm{e}$ & $7,03 \mathrm{~d}$ & $5,06 \mathrm{e}$ \\
\hline
\end{tabular}

Médias seguidas de mesmas letras indicam resultados semelhantes pelo Teste de Tukey à 1\%

Comparação nas colunas

(1) Resíduo não fornece garantia, pois não é um fertilizante

Média de três repetições

Tabela 8 - Solubilidade de Zinco nos extratores, em \% em relação ao teor total.

\begin{tabular}{lrccccc}
\hline \multicolumn{1}{c}{ Fonte } & \multicolumn{1}{c}{ Água } & AC agitação & AC fervura & CNA agitação & CNA fervura & DTPA \\
\hline Gran-o-zinc 20 & $4,03 \mathrm{~d}$ & $76,83 \mathrm{~b}$ & $70,85 \mathrm{~b}$ & $51,46 \mathrm{c}$ & $51,90 \mathrm{~d}$ & $18,98 \mathrm{c}$ \\
Plantzinco FII & $6,11 \mathrm{c}$ & $78,69 \mathrm{~b}$ & $67,03 \mathrm{~b}$ & $52,26 \mathrm{c}$ & $51,48 \mathrm{~d}$ & $29,47 \mathrm{~b}$ \\
Zincogran 20 & $14,56 \mathrm{~b}$ & $77,31 \mathrm{~b}$ & $72,79 \mathrm{~b}$ & $53,26 \mathrm{c}$ & $55,08 \mathrm{~d}$ & $17,53 \mathrm{~cd}$ \\
FMM-100 & $0,24 \mathrm{f}$ & $61,44 \mathrm{c}$ & $57,62 \mathrm{c}$ & $13,84 \mathrm{~d}$ & $31,69 \mathrm{e}$ & $14,67 \mathrm{cde}$ \\
$\mathrm{ZnSO}_{4}$ & $99,85 \mathrm{a}$ & $99,38 \mathrm{a}$ & $99,54 \mathrm{a}$ & $99,44 \mathrm{a}$ & $99,62 \mathrm{a}$ & $78,22 \mathrm{a}$ \\
$\mathrm{ZnO}$ & $0,22 \mathrm{f}$ & $99,70 \mathrm{a}$ & $43,67 \mathrm{~d}$ & $77,75 \mathrm{~b}$ & $90,00 \mathrm{~b}$ & $6,38 \mathrm{e}$ \\
Zn metálico & $0,19 \mathrm{f}$ & $31,61 \mathrm{c}$ & $34,03 \mathrm{e}$ & $12,33 \mathrm{~d}$ & $11,23 \mathrm{e}$ & $7,04 \mathrm{e}$ \\
Resíduo & $1,18 \mathrm{e}$ & $80,55 \mathrm{~b}$ & $27,38 \mathrm{e}$ & $53,86 \mathrm{c}$ & $77,61 \mathrm{c}$ & $8,57 \mathrm{de}$ \\
\hline
\end{tabular}

Médias seguidas de mesmas letras indicam resultados semelhantes pelo Teste de Tukey à $1 \%$

Comparação nas colunas

Média de três repetições 


\subsection{Efeito das fontes e doses de boro e zinco para as plantas}

\subsubsection{Efeito das fontes e doses de boro para a cultura da soja}

\subsubsection{Primeiro cultivo}

\subsection{Matéria seca}

Não houve efeito das fontes, somente houve efeito significativo das doses de fertilizantes na produção de matéria seca, em g vaso ${ }^{-1}$, pelas plantas de soja (Prob.> F = 0,00001). Esse efeito pode ser observado na Figura 1. No final deste trabalho, no item apêndice, estão os quadros de análise de variância para o todos os parâmetros avaliados.

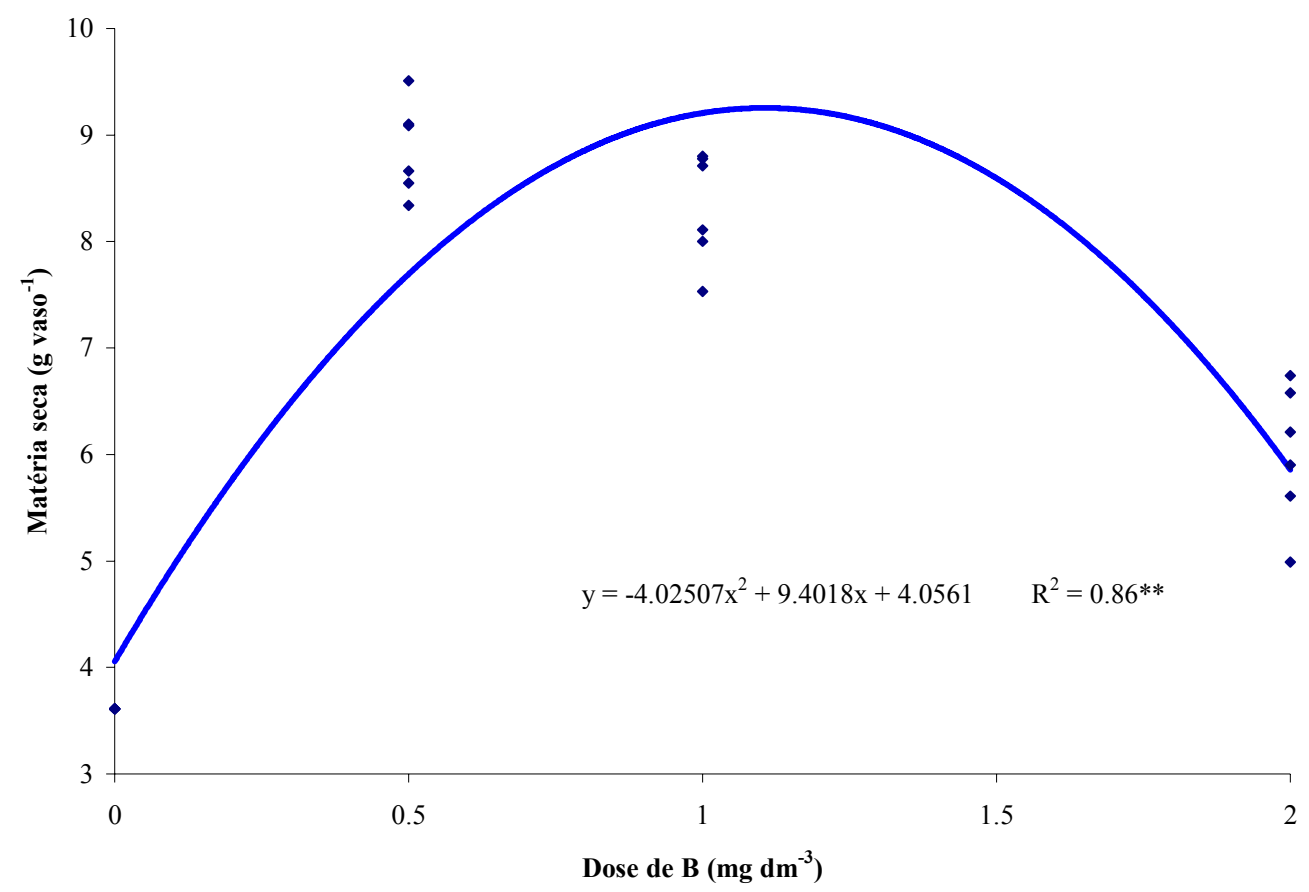

Figura 1 - Efeito das doses de boro na produção de matéria seca, em $\mathrm{g}$ vaso $^{-1}$, por plantas de soja $-1^{\circ}$ cultivo 
$\mathrm{Na}$ Figura 2 observam-se detalhes do tratamento testemunha, com os sintomas de deficiência do elemento apresentados pelas plantas de soja, mostrando que o solo utilizado no experimento foi muito bom para se avaliar a disponibilidade do boro contido nos fertilizantes. $O$ efeito não significativo das fontes indica que a disponibilidade do boro foi semelhante para todos os produtos testados. Os sintomas de deficiência foram semelhantes aos encontrados por Mascarenhas et al. (1988), para a cultura da soja no campo: as folhas primárias mostraram-se coriáceas e espessas, e houve morte da gema apical, com brotamento de gemas laterais, nanismo e poucas flores. No campo, os autores encontraram também pequeno pegamento das vagens e redução da produtividade.

É interessante observar que, a partir de uma certa dose, houve efeito depressivo do boro na produção de matéria seca, ocorrendo, então, toxidez do elemento para as plantas. A dose a partir da qual as plantas começaram a apresentar sintomas de toxidez,

estimada pela equação da reta, foi de $1,106 \mathrm{mg} \mathrm{dm}^{-3}$ de boro. Na Figura 3 observam-se os sintomas de toxidez nas plantas que foram conduzidas em vasos que receberam dose de $2 \mathrm{mg} \mathrm{dm}^{-3}$ de boro. É importante salientar que as plantas que receberam dose $1 \mathrm{mg}$ $\mathrm{dm}^{-3}$ do elemento apresentaram alguns sintomas de toxidez, porém bem menos severos que na maior dose. Mooy et al. (1973) citam que a cultura da soja, por requerer quantidades relativamente baixas de boro, é bem sensível à toxidez. Os sintomas ocorreram na mesma intensidade em todos os tratamentos, e foram semelhantes aos citados por Nable et al. (1997): amarelecimento das pontas das folhas mais velhas, propagando-se para as margens e entre as nervuras laterais, progredindo rapidamente para necrose. As folhas tornaram-se bronzeadas, com aparência de queimadas, caindo prematuramente e causando diminuição no porte das plantas.

\subsection{Teor de boro nas plantas}

Semelhante ao resultado encontrado para o parâmetro matéria seca, somente houve efeito significativo das doses de boro aplicadas no teor de boro, em $\mathrm{mg} \mathrm{kg}^{-1}$, encontrado nas plantas de soja (Prob.> F =0,00001). Esse efeito pode ser observado na 
Figura 4, mostrando um aumento linear do teor de boro nas plantas em função da dose aplicada, resultado semelhante ao encontrado por Buzetti et al. (1990b).

Figura 2 - Sintomas de deficiência de boro nas folhas de soja

Vários trabalhos relacionam o teor de boro nas plantas de soja com os sintomas de deficiência do elemento. Peck (1979) cita o teor de boro menor que $10 \mathrm{mg} \mathrm{kg}^{-1}$ nas folhas como deficiente, enquanto na faixa de 11 a $20 \mathrm{mg} \mathrm{kg}^{-1}$, o teor é considerado baixo. Mascarenhas et al. (1988) encontraram que plantas que no campo mostraram sintomas de deficiência do elemento continham $10 \mathrm{mg} \mathrm{kg}^{-1}$ de boro, enquanto as plantas sem sintomas apresentaram $19 \mathrm{mg} \mathrm{kg}^{-1}$. Neste trabalho, o teor encontrado nas plantas 
com sintomas de deficiência foi em média $17,57 \mathrm{mg} \mathrm{kg}^{-1}$ de boro, superior ao valor de deficiência encontrado pelos referidos autores, e bem próximo ao das plantas sem sintomas.

O teor foliar de boro superior a $80 \mathrm{mg} \mathrm{dm}^{-3}$ é considerado como causador de toxidez para as plantas de soja, segundo Peck (1979). Já Gabe (1998), ao adicionar aproximadamente $3 \mathrm{mg} \mathrm{dm}^{-3}$ de boro através de uma mistura calcário + rocha fosfatada + 4-14-8 + "frita" BR-5, encontrou sintomas de toxidez nas plantas de soja, com o teor foliar chegando próximo de $100 \mathrm{mg} \mathrm{kg}^{-1}$. No presente trabalho, considerando que a partir da dose de 1,106 $\mathrm{mg} \mathrm{dm}^{-3}$ de boro as plantas começaram a apresentar diminuição na produção de matéria seca e sintomas de toxidez do elemento, encontram-se plantas que continham teores de boro maiores ou iguais a $104,85 \mathrm{mg} \mathrm{kg}^{-1}$ de matéria seca, apresentaram esses sintomas.

Figura 3 - Sintomas de toxidez de boro em planta de soja que cresceu em solo que recebeu $2 \mathrm{mg} \mathrm{dm}^{-3}$ de boro 


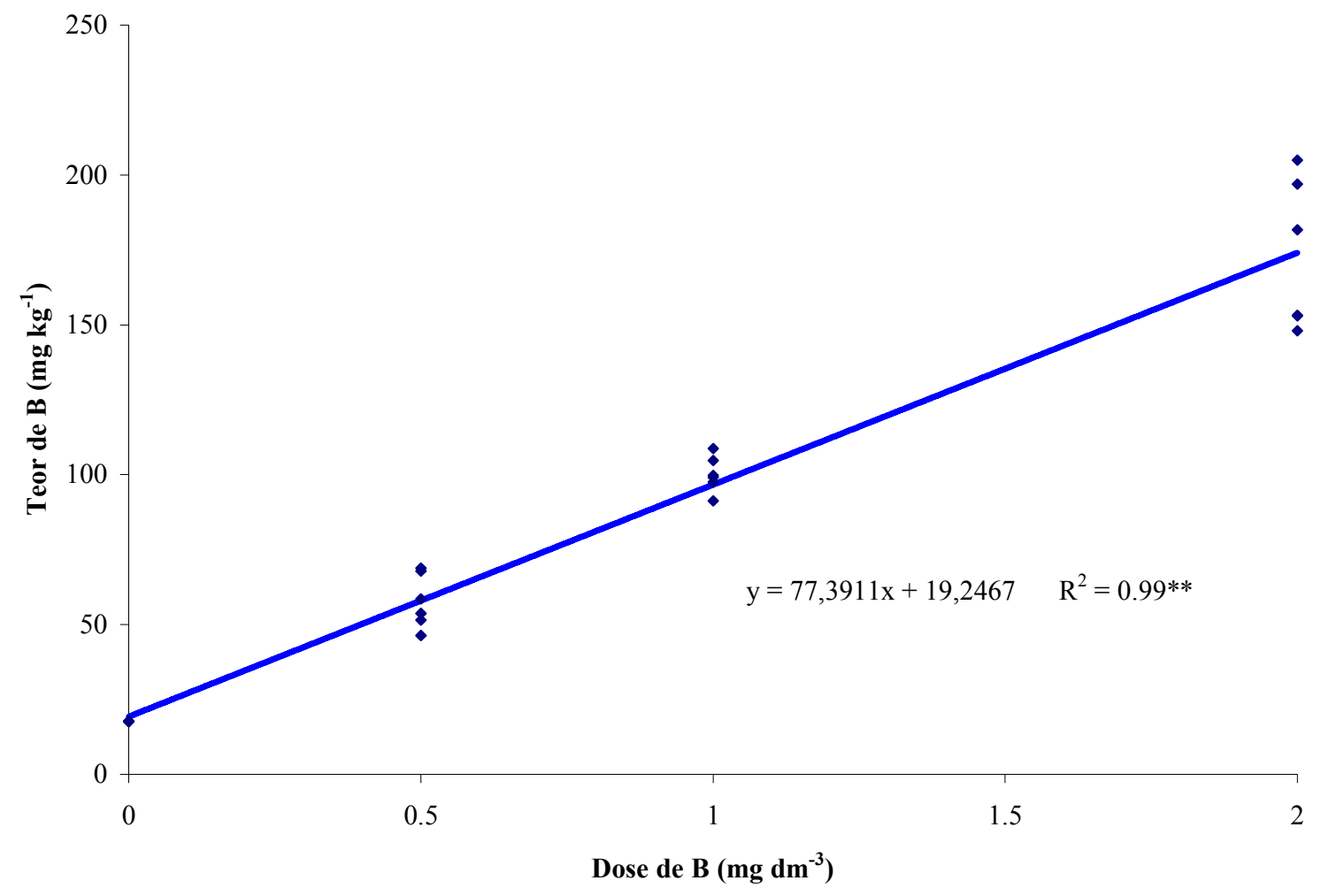

Figura 4 - Efeito das doses de boro no teor do elemento, em $\mathrm{mg} \mathrm{kg}^{-1}$, nas plantas de soja $-1^{\mathrm{o}}$ cultivo

\subsection{Conteúdo de boro nas plantas}

Semelhante ao que ocorreu nos parâmetros anteriores, observou-se que somente houve efeito das doses de boro aplicada no conteúdo do elemento nas plantas (Prob.> F $=0,00001)$. O fator conteúdo é muito importante no estudo da disponibilidade de nutrientes em fertilizantes, pois representa a quantidade real do elemento que está contida nas plantas, o quanto o fertilizante teve capacidade em fornecer o nutriente.

O efeito das doses de boro no conteúdo do elemento nas plantas de soja está ilustrado na Figura 5, mostrando um aumento quadrático da quantidade de boro nas plantas em função do aumento da dose de boro fornecida aos tratamentos. A semelhança 
dos resultados encontrados no primeiro cultivo de soja, isto é, as seis fontes de boro utilizadas foram iguais quanto à produção de matéria seca, teor e conteúdo de boro nas plantas, mostra que a disponibilidade do elemento em todos os produtos foi semelhante. As fontes ácido bórico, ulexita e colemanita são reconhecidas como fertilizantes com micronutrientes pela legislação. Já as “fritas” são produzidas a partir de uma matériaprima que contenha boro. Pela semelhança dos resultados pode-se supor que foi utilizado uma fonte reconhecida como fertilizante para a fabricação das mesmas. Pelas características de solubilidade em água dessas fontes, é grande a possibilidade delas terem sido preparadas a partir da ulexita. Alcarde \& Vale (1999) citam que, para o boro, pelo fato de ser um elemento não metálico, não existe um produto alternativo para ser utilizado como matéria-prima, a não ser as fontes do elemento definidas como fertilizantes pela legislação brasileira.

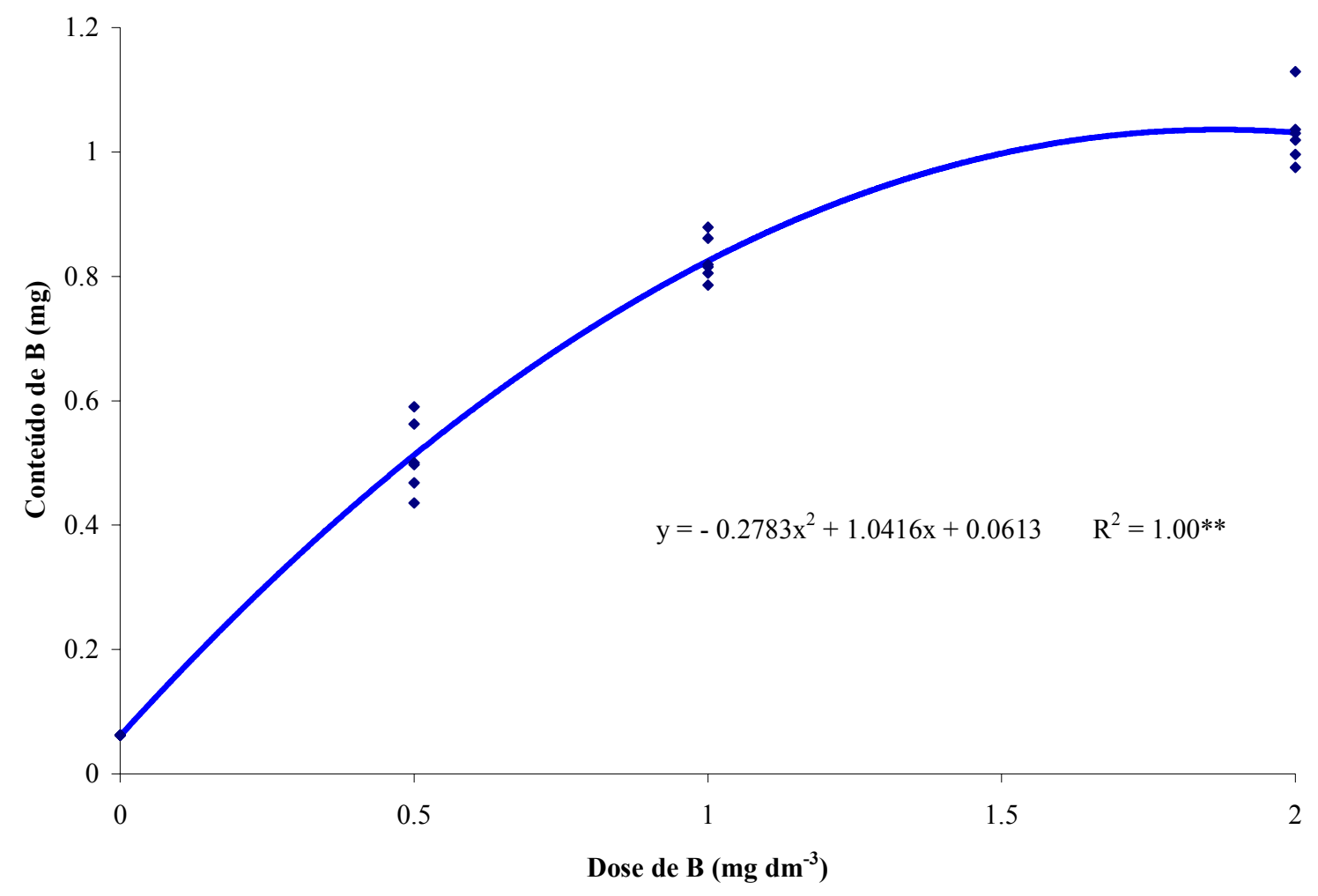

Figura 5 - Efeito das doses de boro no conteúdo do elemento, em mg, nas plantas de soja $-1^{\underline{o}}$ cultivo 


\subsubsection{Teor de boro residual no solo}

Semelhante ao encontrado nos casos anteriores, somente houve efeito das doses de boro aplicadas no teor residual de boro encontrado nos solos após a retirada das plantas de soja, em $\mathrm{mg} \mathrm{dm}^{-3}$, extraído em solução de cloreto de bário a quente (Prob.> F $=0,00001)$. Estes resultados evidenciam ainda mais a semelhança de disponibilidade do boro, devido ao uso de fontes reconhecidas como fertilizantes pela legislação. O efeito das doses está representado na Figura 6, mostrando um aumento linear do teor de boro no solo em função do aumento da dose do elemento. Resultados semelhantes foram encontrados por Buzetti et al. (1990a).

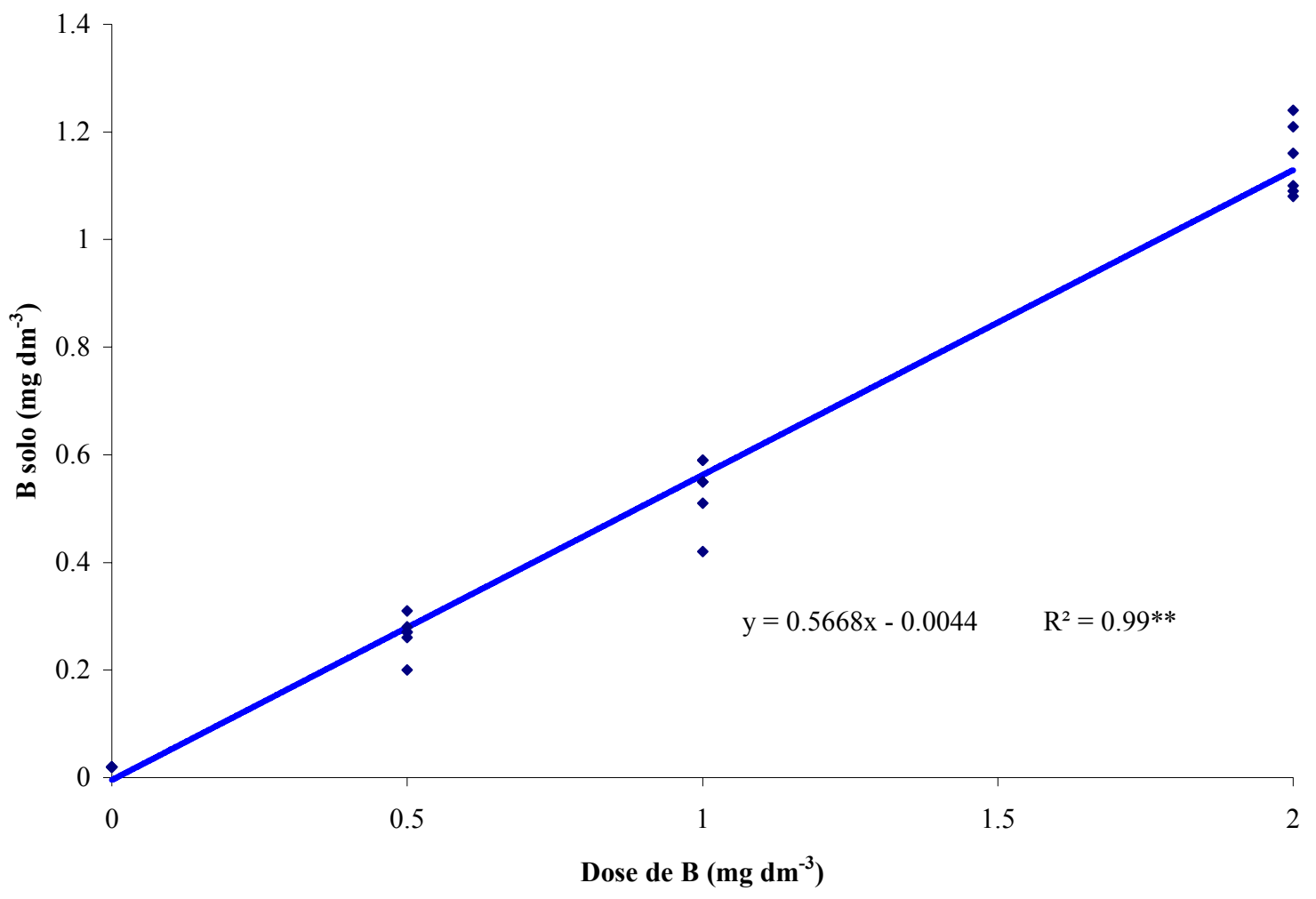

Figura 6 - Efeito das doses de boro no teor do elemento, em $\mathrm{mg} \mathrm{dm}^{-3}$, extraído por solução de cloreto de bário a quente do solo 


\subsubsection{Segundo cultivo}

\subsection{Matéria seca}

Semelhante ao encontrado para a produção de matéria seca no primeiro corte, somente ocorreu efeito significativo das doses de boro utilizadas na produção de matéria seca, em $g$ vaso $^{-1}$, no segundo cultivo de soja. (Prob. $>\mathrm{F}=0,00001$ ), como pode ser observado na Figura 7.

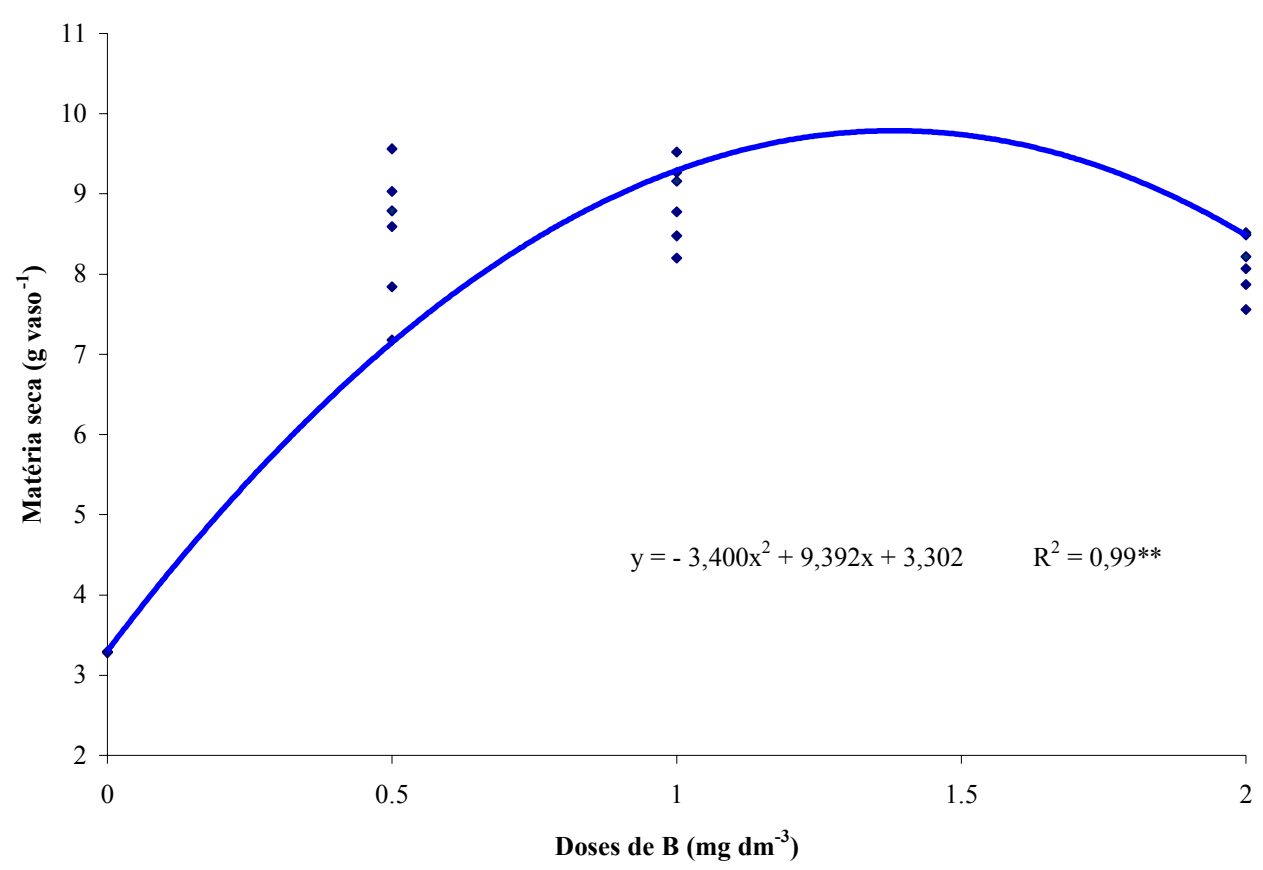

Figura 7 - Efeito residual das doses de boro na produção de matéria seca, em g vaso ${ }^{-1}$, por plantas de soja $-2^{\underline{o}}$ cultivo

Esse efeito das doses é concordante com os resultados encontrados para quantidade residual de boro no solo, iguais para todas as fontes. É interessante salientar que, igual ao que ocorreu no primeiro corte, as plantas do tratamento testemunha apresentaram sintomas de deficiência do elemento. Porém, a produção de matéria seca das plantas do segundo corte neste tratamento foi inferior aos da testemunha no primeiro 
corte, pois após o primeiro cultivo a quantidade de boro do solo diminuiu, extraído pelas primeiras plantas. Observou-se, também, que na dose mais elevada do elemento ainda ocorreram sintomas de toxidez para as plantas de soja, com diminuição da quantidade de matéria seca produzida. Esses sintomas foram, porém, menos severos do que os apresentados pelas plantas no primeiro corte. Isto porque a quantidade de boro residual nos tratamentos que receberam dose inicial de boro igual a $2 \mathrm{mg} \mathrm{dm}^{-3}$ era de aproximadamente $1,09 \mathrm{mg} \mathrm{dm}^{-3}$ (Figura 6), semelhante à dose no primeiro experimento na qual as plantas de soja começaram a apresentar os sintomas de toxidez $\left(1,106 \mathrm{mg} \mathrm{dm}^{-3}\right)$.

\subsection{Teor de boro nas plantas}

Observou-se que, diferente dos outros parâmetros já analisados, houve efeito significativo à $1 \%$ das doses de boro utilizadas (Prob. $>\mathrm{F}=0,00001$ ) e, também, efeito significativo à $5 \%$ das fontes de boro testadas(Prob.> F = 0,02525), sobre os teores de boro, em mg kg ${ }^{-1}$, nas plantas de soja no segundo corte

Na Figura 8 encontra-se o efeito residual das fontes de boro testadas, no teor de elemento encontrado nas plantas de soja no $2^{\underline{0}}$ corte. Observa-se que o ácido bórico proporcionou um maior teor de boro para as plantas, enquanto que o tratamento MIB - 4 foi o que menos favoreceu a absorção do elemento pela cultura da soja. Esse comportamento não pode ser explicado pelas diferenças de solubilidade entre os fertilizantes em nenhum dos extratores avaliados, pois apesar do ácido bórico ter sido o fertilizante mais solúvel em água, o MIB - 4 apresentou uma solubilidade neste extrator maior que ulexita e colemanita, por exemplo (Tabela 5). Ocorreu, provavelmente, um problema experimental, pois o teor de boro apresentado pelas plantas no tratamento MIB - 4, dose $2 \mathrm{mg} \mathrm{dm}^{-3}$ foi inferior aos apresentados nas doses $0,5 \mathrm{e} 1 \mathrm{mg} \mathrm{dm}^{-3}$.

Na figura 9 observa-se o efeito linear positivo das doses de boro utilizadas no teor do elemento nas plantas de soja. Percebe-se que o problema experimental provavelmente ocorrido com a fonte MIB - 4 na dose $2 \mathrm{mg} \mathrm{dm}^{-3}$ teve uma grande influência no efeito das doses, causando uma diminuição da inclinação da reta. 


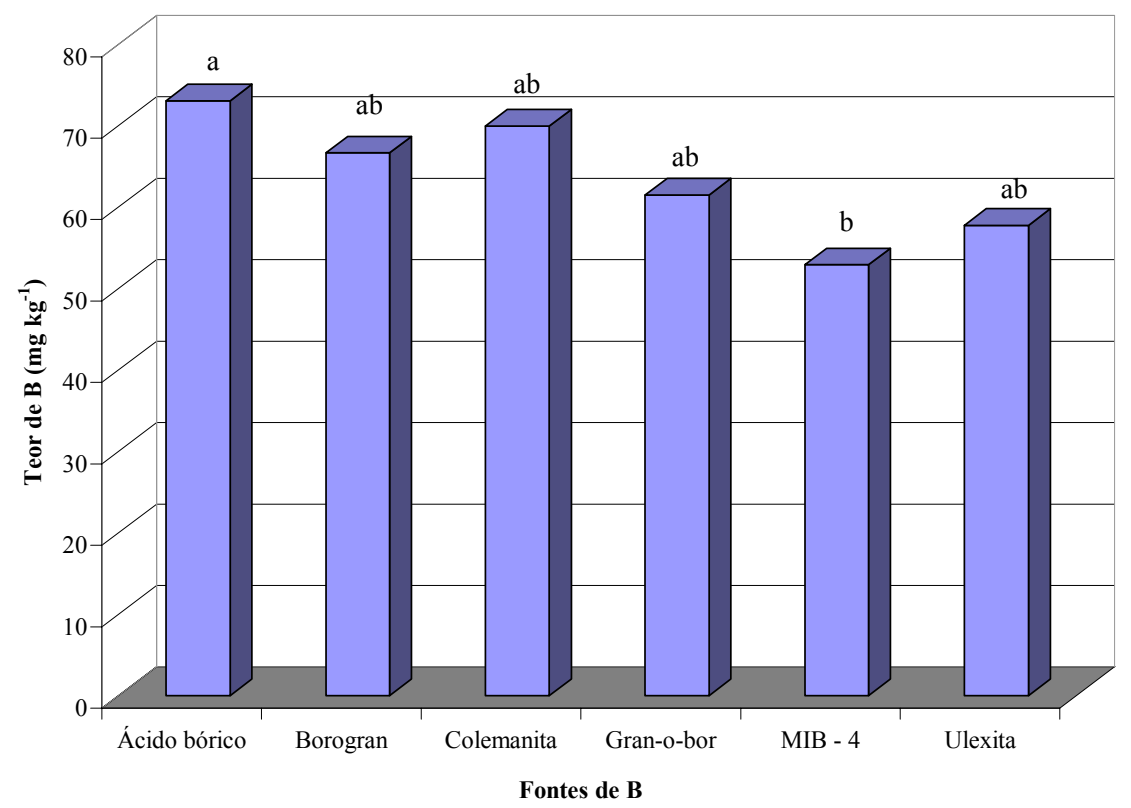

Figura 8 - Efeito das fontes de boro no teor do elemento, em $\mathrm{mg} \mathrm{kg}^{-1}$, encontrado nas plantas de soja $-2^{\underline{0}}$ cultivo (Médias com mesma letra são iguais à 5\%)

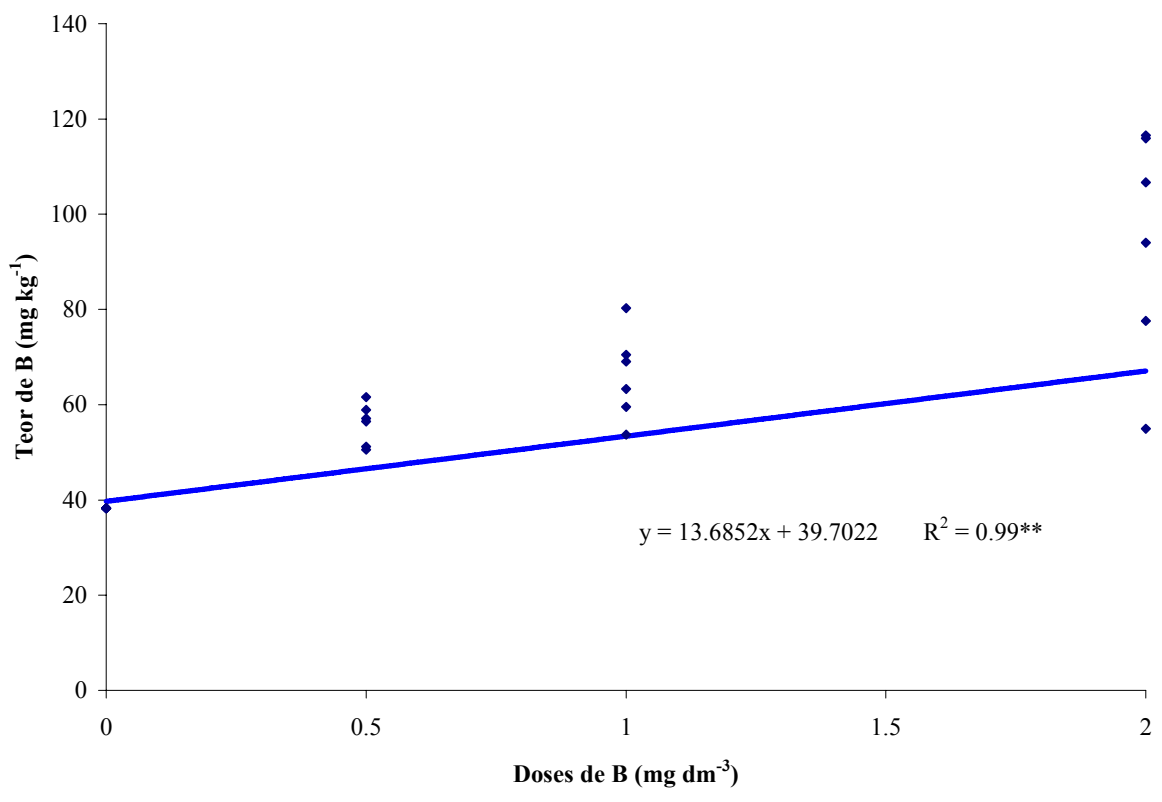

Figura 9 - Efeito residual das doses de boro no teor do elemento, em $\mathrm{mg} \mathrm{kg}^{-1}$, encontrado nas plantas de soja $-2^{\underline{o}}$ cultivo 


\subsection{Conteúdo de boro nas plantas}

Semelhante ao que foi encontrado para teor de boro nas plantas, observou-se um efeito significativo à $1 \%$ das doses de boro utilizadas (Prob.> F $=0,00001$ ) e, também, efeito significativo à $5 \%$ das fontes testadas (Prob. $>\mathrm{F}=0,03288)$, no conteúdo de boro, em mg, nas plantas de soja. Esta semelhança entre os dois parâmetro ocorreu devido ao conteúdo de boro nas plantas ser um reflexo do teor encontrado, pois não houve diferença significativa entre as fontes quanto à produção de matéria seca.

O efeito tanto das fontes, como das doses de boro no conteúdo do elemento nas plantas foi semelhante ao que ocorreu na análise do parâmetro teor de boro, novamente devido ao problema ocorrido com a fonte MIB - 4 na dose $2 \mathrm{mg} \mathrm{dm}{ }^{-3}$, conforme pode ser observado nas Figuras 10 e 11.

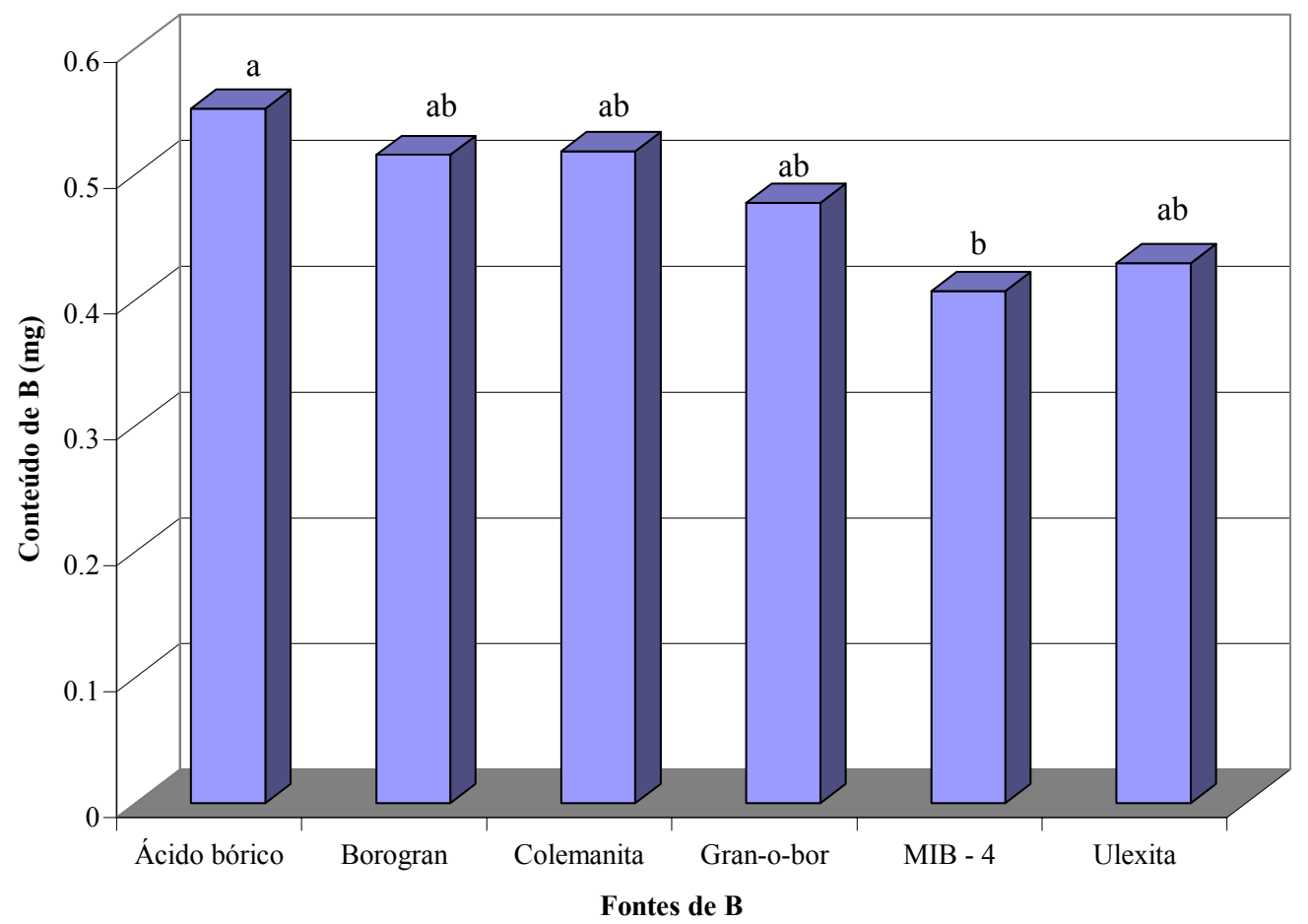

Figura 10 - Efeito residual das fontes de boro no conteúdo do elemento, em mg, nas plantas de soja $-2^{-}$cultivo (Médias com letras iguais não diferem à $5 \%$ ) 


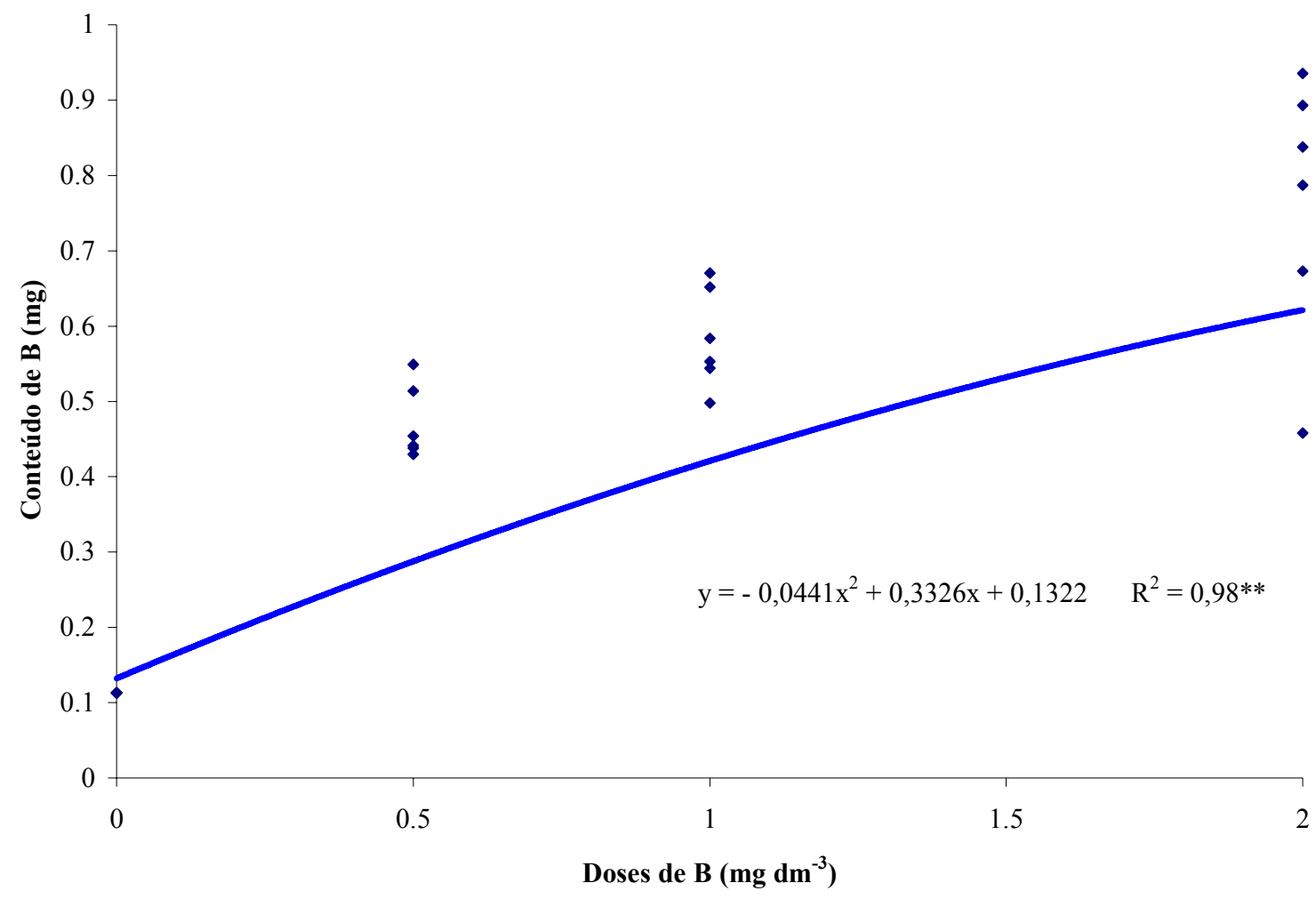

Figura 11 - Efeito residual das doses de boro no conteúdo do elemento, em mg, nas plantas de soja $-2^{\underline{o}}$ cultivo

Na Figura 12 observa-se a relação quadrática e significativa encontrada entre o teor de boro residual no solo após o primeiro cultivo e o conteúdo de boro nas plantas no segundo cultivo. Apesar da dispersão apresentada por alguns pontos, no geral, a solução de cloreto de bário a quente mostrou-se um bom extrator para avaliar o boro disponível do solo, como citado por Buzetti et al. (1990a).

Por todos os resultados apresentados para o efeito das fontes e doses de boro na produção de matéria seca, teor e conteúdo do elemento nas plantas, assim como para teor de boro solúvel em solução de cloreto de bário, pode-se concluir que todas as fontes foram semelhantes quanto a disponibilidade do elemento. 


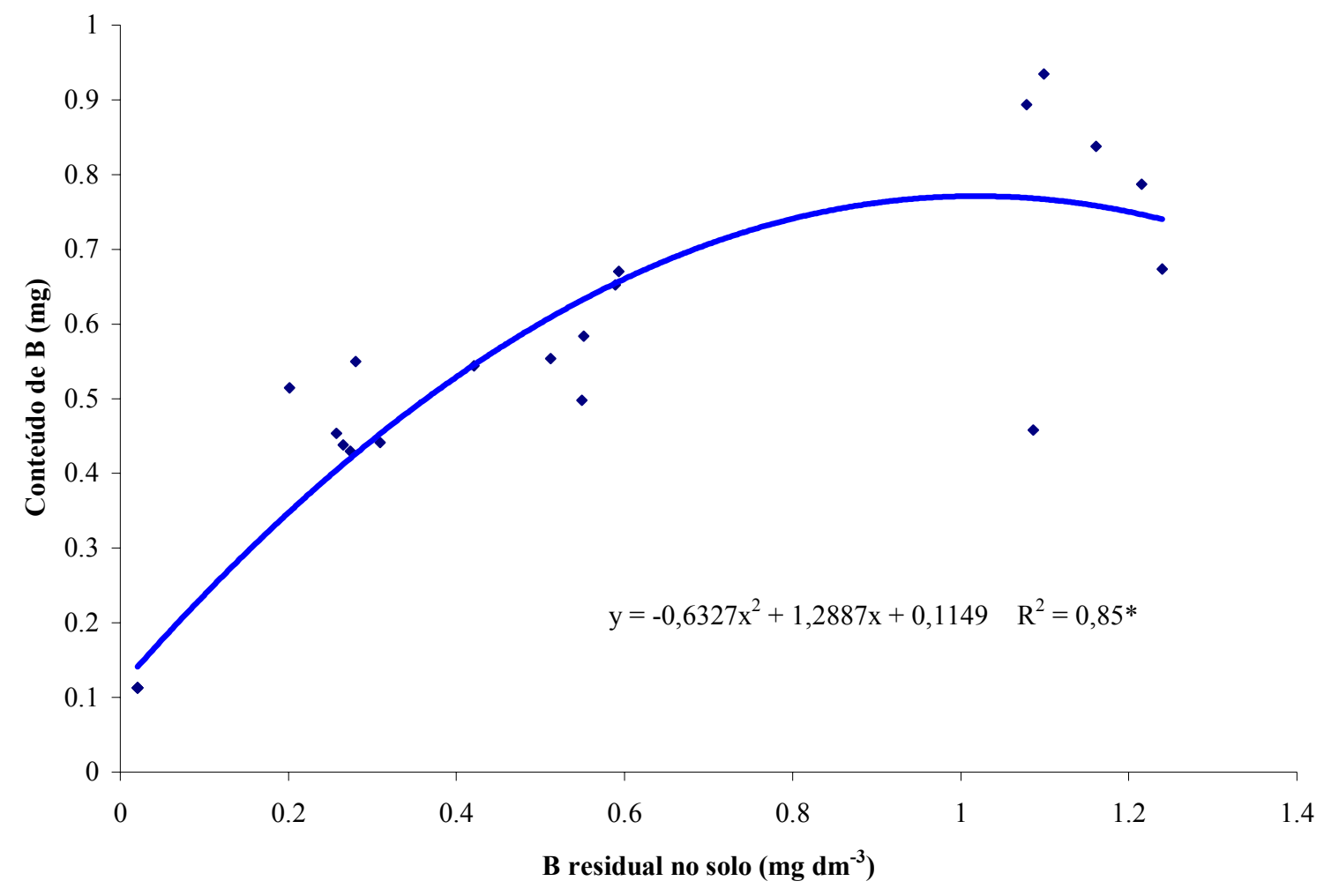

Figura 12 - Relação entre boro residual no solo, solúvel em solução de cloreto de bário a quente, após o primeiro cultivo e o conteúdo do elemento encontrado no segundo cultivo de soja.

\subsubsection{Efeito das fontes e doses de zinco para a cultura do arroz}

\subsubsection{Primeiro cultivo}

\subsection{Matéria seca}

Observa-se que somente houve efeito significativo das doses de zinco utilizadas na produção de matéria seca pelas plantas de arroz (Prob.> F $=0,00077$ ), com as fontes 
não influindo significativamente neste parâmetro. Esse efeito significativo das doses está ilustrado na Figura 13. Observa-se uma grande dispersão dos pontos e um baixo coeficiente de determinação, indicando que o efeito das doses de zinco foi pequeno. Era de se esperar uma maior resposta a esse parâmetro, pois o arroz é uma planta exigente em zinco, e o solo estava originalmente com teores muito baixos do elemento.

\subsection{Teor de zinco nas plantas}

Diferente dos resultados encontrados na avaliação da matéria seca, houve efeito significativo da interação fontes e doses de zinco sobre o teor de zinco, em $\mathrm{mg} \mathrm{kg}^{-1}$, encontrado nas plantas de arroz (Prob. $>\mathrm{F}=0,00163$ ).

Na Tabela 9 está indicado o efeito das fontes dentro do fator doses de zinco, no teor de zinco, em $\mathrm{mg} \mathrm{kg}^{-1}$, encontrado nas plantas de arroz. Observa-se que nas doses mais baixas do elemento não houve diferença significativa das fontes de zinco no fornecimento do elemento para as culturas. Porém, nas duas maiores doses, os tratamentos que receberam sulfato e óxido de zinco, pela ordem, tiveram um teor mais elevado do elemento. Também esse comportamento foi observado para os valores médios absorvidos, fornecidos por cada fonte do elemento. O resultado fica bastante interessante quando se compara o teor de zinco nos tratamentos que receberam os produtos tipo "fritas" (Gran-o-zinc, Plantzinco e Zincogran), isto é, os três produtos tiveram capacidade semelhante em fornecer o zinco para as plantas, e inferiores ao óxido e sulfato. A forma química do zinco nestes três produtos mostra-se diferente, indicando a utilização de subprodutos industriais na fabricação desses fertilizantes. Como na indústria esses produtos sofrem uma solubilização apenas parcial, seguida de granulação, continuam a existir formas metálicas, não reconhecidas como fertilizantes pela legislação, e que possuem eficiência agronômica menor que o zinco oriundo do óxido e do sulfato, produtos com reconhecida eficiência fertilizante, e considerados como tal pela legislação. Quanto à fonte metálica utilizada, observou-se que, apesar de possuir uma solubilidade menor em todos os extratores, apresentou igual disponibilidade 
às plantas, mostrando que mesmo produtos com essa forma química conseguem, no solo, solubilizar parcialmente através de reações de oxi-redução, principalmente considerando-se que este produto estava em forma de pó muito fino.

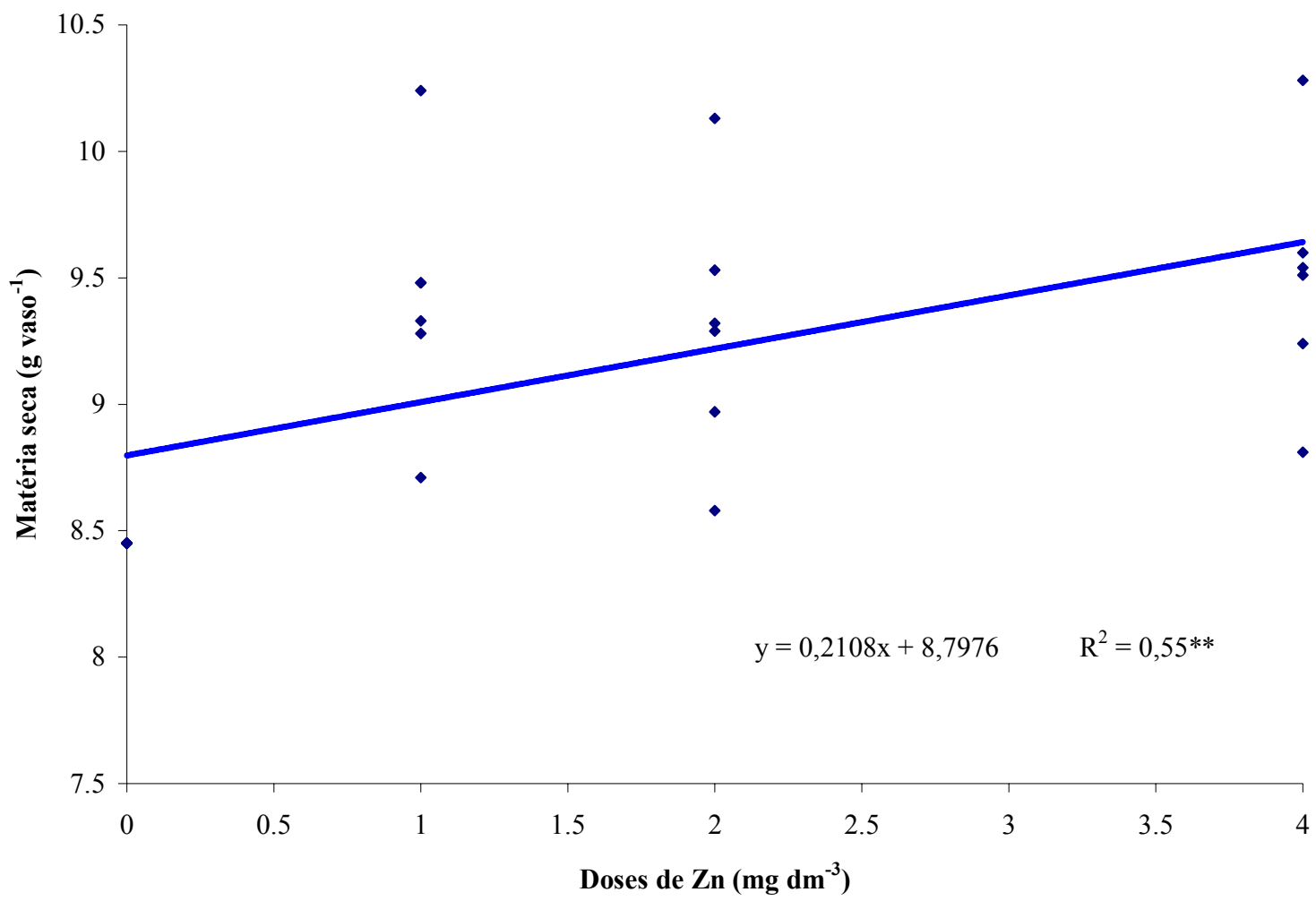

Figura 13 - Efeito das doses de zinco utilizadas na produção de matéria seca, em $\mathrm{g}$ vaso $^{-1}$, pelas plantas de arroz- $1^{\underline{0}}$ cultivo 
Tabela 9 - Efeito das fontes dentro do fator doses, no teor de zinco, em $\mathrm{mg} \mathrm{kg}{ }^{-1}$, encontrado nas plantas de arroz - $1^{\circ}$ cultivo. Média das três repetições

\begin{tabular}{|c|c|c|c|c|c|}
\hline \multirow{2}{*}{ Fontes } & \multicolumn{4}{|c|}{ Doses de zinco $\left(\mathrm{mg} \mathrm{dm}^{-3}\right)$} & \multirow{2}{*}{ Média } \\
\hline & 0 & 1 & 2 & 4 & \\
\hline Gran-o-zinc & $10,37 \mathrm{a}$ & $11,50 \mathrm{a}$ & $12,43 \mathrm{~b}$ & $16,00 \mathrm{c}$ & $12,57 \mathrm{c}$ \\
\hline Plantzinco & $10,37 \mathrm{a}$ & $12,40 \mathrm{a}$ & $13,03 \mathrm{~b}$ & $16,37 \mathrm{c}$ & $13,04 \mathrm{c}$ \\
\hline Zincogran & $10,37 \mathrm{a}$ & $11,30 \mathrm{a}$ & $13,97 \mathrm{~b}$ & $16,10 \mathrm{c}$ & $12,93 \mathrm{c}$ \\
\hline Metálico & $10,37 \mathrm{a}$ & $12,30 \mathrm{a}$ & $14,73 \mathrm{ab}$ & $18,06 \mathrm{bc}$ & $13,87 \mathrm{bc}$ \\
\hline Óxido & $10,37 \mathrm{a}$ & $13,10 \mathrm{a}$ & $18,60 \mathrm{ab}$ & $23,37 \mathrm{ab}$ & $16,36 \mathrm{ab}$ \\
\hline Sulfato & $1037 \mathrm{a}$ & $11,77 \mathrm{a}$ & $20,97 \mathrm{a}$ & $26,23 \mathrm{a}$ & $17,33 \mathrm{a}$ \\
\hline Média & 10,37 & 12,06 & 15,62 & 19,35 & \\
\hline
\end{tabular}

$\mathrm{Na}$ Figura 14 são apresentadas as regressões lineares para as doses de zinco dentro do fator fontes, mostrando um efeito linear entre a quantidade de zinco, aplicada em cada tratamento, e o teor do elemento absorvido pelas plantas de arroz. É evidenciada a maior disponibilidade do elemento contido nas fontes sulfato e óxido de zinco, em detrimento das "fritas" e do zinco aplicado sob forma metálica. Observa-se que, para esses quatro últimos produtos, a variação entre o teor de zinco nos tratamentos que receberam dose $1 \mathrm{mg} \mathrm{dm}^{-3}$ e os que receberam a maior dose do elemento foi muito pequena. Apesar de não ter ocorrido efeito na produção de matéria seca, em campo isso pode ser um grande diferencial, principalmente pensando-se que neste experimento, por ter sido realizado em vasos, não foi avaliada a produção de grãos de arroz, o principal objetivo de quem planta a cultura. Por isso essa avaliação da disponibilidade dos micronutrientes para as plantas é muito importante. 


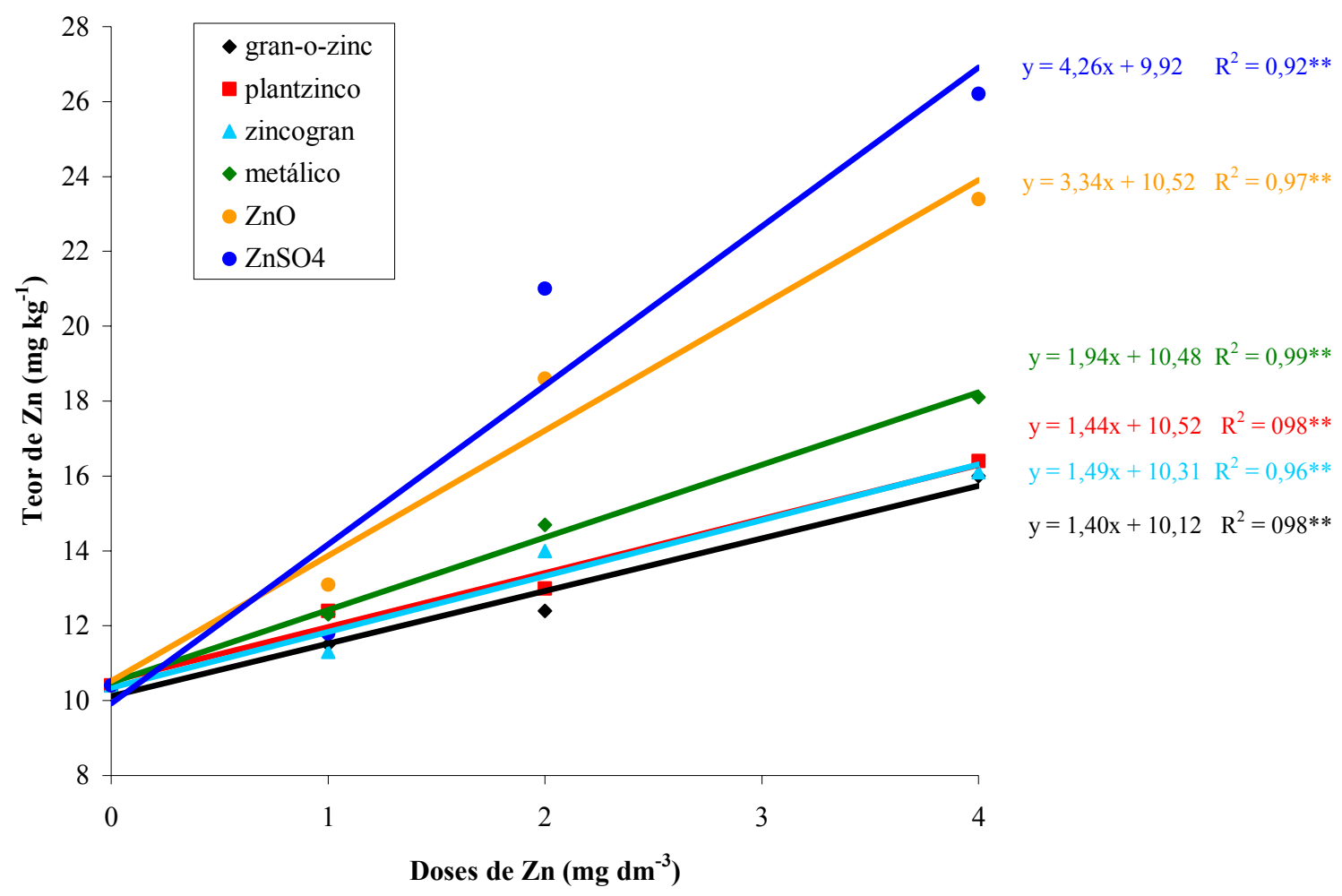

Figura 14 - Efeito das doses dentro do fator fontes, no teor de zinco, em $\mathrm{mg} \mathrm{kg}^{-1}$, encontrado nas plantas de arroz - $1^{\underline{0}}$ cultivo

\subsection{Conteúdo de zinco nas plantas}

Semelhante ao resultado encontrado para teor de zinco, observou-se interação significativa entre fontes e doses do elemento, ao nível de 5\% de probabilidade (Prob.> $\mathrm{F}=0,01487$ ) no conteúdo do elemento, em $\mathrm{mg}$, nas plantas de arroz.

$\mathrm{Na}$ Tabela 10 está indicado o efeito das fontes dentro do fator doses de zinco no conteúdo de zinco, em mg, encontrado nas plantas de arroz. Observa-se que os resultados foram bem semelhantes aos encontrados para o parâmetro teor de zinco. Nas doses mais baixas do elemento não houve diferença significativa das fontes de zinco no fornecimento do elemento para as cultura. Já nas duas maiores doses, os tratamento que receberam, pela ordem, os fertilizantes sulfato e óxido de zinco tiveram um maior conteúdo de zinco acumulado pelas plantas. Comportamento semelhante foi observado 
para os valores médios absorvidos fornecidos por cada fonte do elemento. Novamente é pertinente se comparar o conteúdo de zinco nos tratamentos que receberam os produtos tipo "fritas" (Gran-o-zinc, Plantzinco e Zincogran), mostrando que todos tiveram capacidade semelhante em fornecer o zinco para as plantas; porém as fontes óxido e sulfato foram mais eficientes no fornecimento do elemento. A forma química do zinco nestes três produtos mostra-se diferente, indicando a utilização de subprodutos industriais na fabricação desses fertilizantes tipo "fritas". O comportamento do produto metálico também foi semelhante ao que ocorreu na análise do teor de zinco nas plantas: apesar de possuir uma solubilidade menor em todos os extratores, apresentou igual disponibilidade às plantas, mostrando que mesmo produtos com essa forma química conseguem, no solo, solubilizar-se parcialmente, principalmente considerando-se que este produto estava sob forma de pó muito fino.

Tabela 10 - Efeito das fontes dentro do fator doses, no conteúdo de zinco, em mg, encontrado nas plantas de arroz - $1^{\underline{0}}$ cultivo.

\begin{tabular}{|c|c|c|c|c|c|}
\hline \multirow{2}{*}{ Fontes } & \multicolumn{4}{|c|}{ Doses de zinco $\left(\mathrm{mg} \mathrm{dm}^{-3}\right)$} & \multirow{2}{*}{ Média } \\
\hline & 0 & 1 & 2 & 4 & \\
\hline Gran-o-zinc & $0,088 \mathrm{a}$ & $0,107 \mathrm{a}$ & $0,119 \mathrm{~b}$ & $0,166 \mathrm{c}$ & $0,120 \mathrm{c}$ \\
\hline Plantzinco & $0,088 \mathrm{a}$ & $0,116 \mathrm{a}$ & $0,132 \mathrm{~b}$ & $0,144 \mathrm{c}$ & $0,120 \mathrm{c}$ \\
\hline Zincogran & $0,088 \mathrm{a}$ & $0,098 \mathrm{a}$ & $0,126 b$ & $0,154 \mathrm{c}$ & $0,116 \mathrm{c}$ \\
\hline Metálico & $0,088 \mathrm{a}$ & $0,116 \mathrm{a}$ & $0,126 \mathrm{~b}$ & $0,167 \mathrm{bc}$ & $0,124 \mathrm{bc}$ \\
\hline Óxido & $0,088 \mathrm{a}$ & $0,119 \mathrm{a}$ & $0,171 \mathrm{a}$ & $0,225 \mathrm{ab}$ & $0,152 \mathrm{ab}$ \\
\hline Sulfato & $0,088 \mathrm{a}$ & $0,124 \mathrm{a}$ & $0,196 \mathrm{a}$ & $0,249 \mathrm{a}$ & $0,163 \mathrm{a}$ \\
\hline Média & 0,088 & 0,113 & 0,145 & 0,184 & \\
\hline
\end{tabular}

As regressões lineares para as doses de zinco dentro do fator fontes são apresentadas na Figura 15. Observa-se um efeito linear entre a quantidade de zinco aplicada em cada tratamento, no conteúdo do elemento absorvido pelas plantas de arroz, com maior disponibilidade do elemento contido nas fontes sulfato e óxido de zinco, em comparação com as "fritas” e o zinco metálico. 


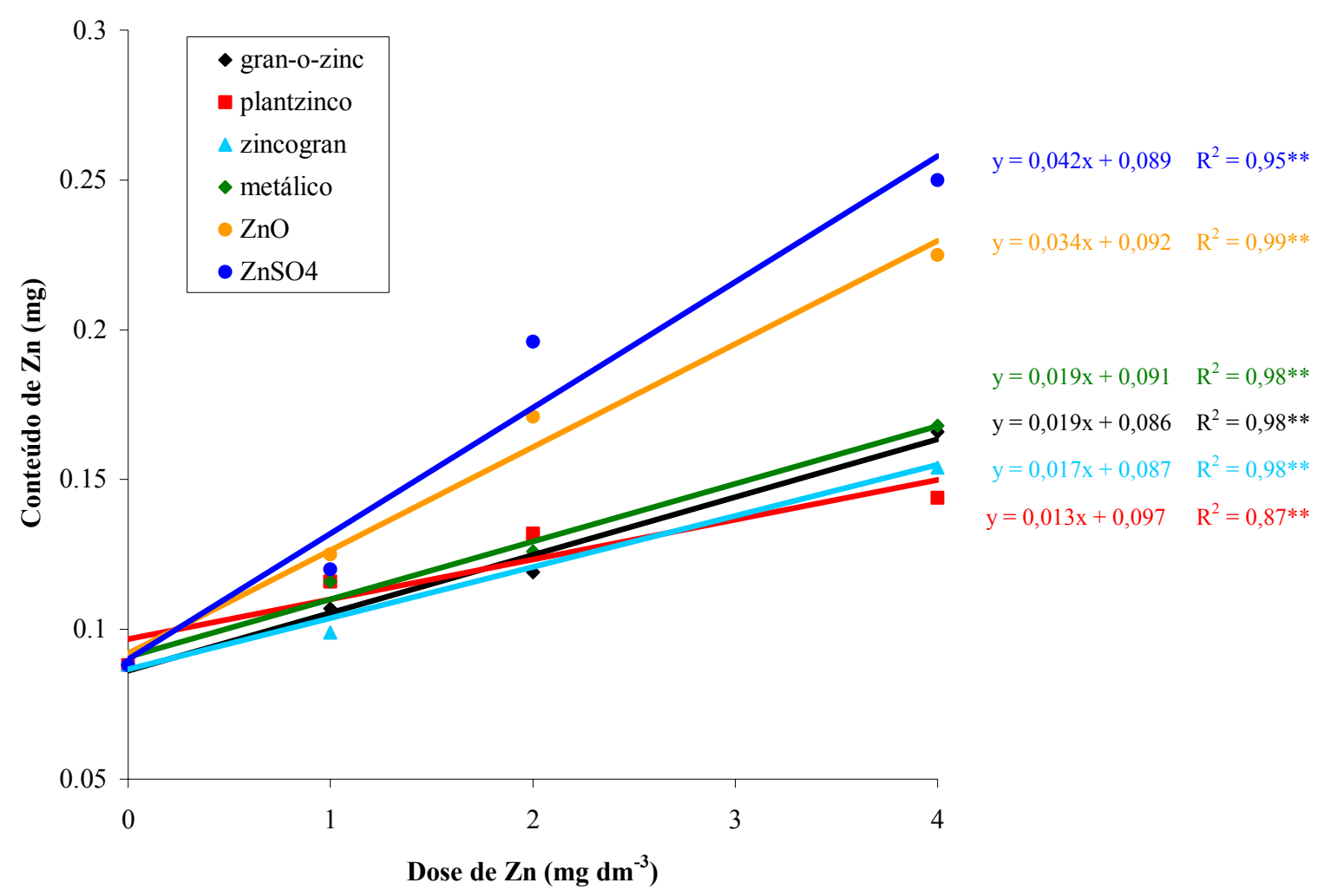

Figura 15 - Efeito das doses dentro do fator fontes, no conteúdo de zinco, em mg, encontrado nas plantas de arroz - $1^{\circ}$ cultivo

\subsubsection{Teor de zinco residual no solo}

Também neste parâmetro foi encontrado efeito significativo à $1 \%$ de probabilidade (Prob.> F = 0,00001), da interação entre as fontes e doses de zinco, no teor do elemento residual solúvel em DTPA, no solo, em $\mathrm{mg} \mathrm{dm}^{-3}$, após o primeiro cultivo de arroz. Na Tabela 11 encontra-se o efeito das fontes dentro do fator doses de zinco, no teor residual do elemento no solo. Neste caso, já se observa um efeito diferenciado das fontes a partir da dose mais baixa aplicada, novamente com a fonte sulfato, seguido pelo óxido de zinco, apresentando maior residual do elemento no solo, 
evidenciando suas maiores disponibilidades em relação as demais, como já demonstrado para os parâmetros teor e conteúdo de zinco nas plantas de arroz. Entre as fontes "fritas", observa-se um melhor desempenho da Plantzinco em relação as outras duas, Gran-o-zinc e Zincogran. A maior disponibilidade do sulfato e óxido de zinco é observada nas regressões lineares das doses de zinco dentro do fator fontes, apresentadas na Figura 16, observando-se um efeito quadrático entre a quantidade de zinco aplicada em cada tratamento, com o teor residual do elemento no solo, solúvel em solução de DTPA.

Tabela 11 - Efeito das fontes dentro do fator doses, no teor de zinco residual no solo, em $\mathrm{mg} \mathrm{dm}{ }^{-3}$, solúvel em solução de DTPA.

\begin{tabular}{|c|c|c|c|c|c|}
\hline \multirow{2}{*}{ Fontes } & \multicolumn{4}{|c|}{ Doses de zinco $\left(\mathrm{mg} \mathrm{dm}^{-3}\right)$} & \multirow{2}{*}{ Média } \\
\hline & 0 & 1 & 2 & 4 & \\
\hline Gran-o-zinc & $0,487 \mathrm{a}$ & $0,573 \mathrm{c}$ & $0,920 \mathrm{c}$ & $1,033 \mathrm{~d}$ & $0,753 \mathrm{~d}$ \\
\hline Plantzinco & $0,487 \mathrm{a}$ & $0,780 \mathrm{ab}$ & $1,110 \mathrm{ab}$ & $1,340 \mathrm{bc}$ & $0,929 \mathrm{~b}$ \\
\hline Zincogran & $0,487 \mathrm{a}$ & $0,733 \mathrm{bc}$ & $0,877 \mathrm{c}$ & $1,280 \mathrm{bc}$ & $0,844 \mathrm{c}$ \\
\hline Metálico & $0,487 \mathrm{a}$ & $0,793 \mathrm{ab}$ & $0,993 \mathrm{bc}$ & $1,240 \mathrm{c}$ & $0,878 \mathrm{bc}$ \\
\hline Óxido & $0,487 \mathrm{a}$ & $0,913 \mathrm{a}$ & $1,240 \mathrm{a}$ & $1,440 \mathrm{~b}$ & $1,020 \mathrm{a}$ \\
\hline Sulfato & $0,487 \mathrm{a}$ & $0,920 \mathrm{a}$ & $1,246 \mathrm{a}$ & $1,643 \mathrm{a}$ & $1,074 \mathrm{a}$ \\
\hline Média & 0,487 & 0,785 & 1,064 & 1,329 & \\
\hline
\end{tabular}

\subsubsection{Segundo cultivo}

\subsection{Matéria seca}

Houve efeito significativo isolado das fontes (Prob. $>\mathrm{F}=0,00253$ ) e das doses de zinco (Prob.> F =0,00001), ambas à 1\%, na produção de matéria seca, em g vaso ${ }^{-1}$, pelas plantas de arroz, no segundo cultivo. 


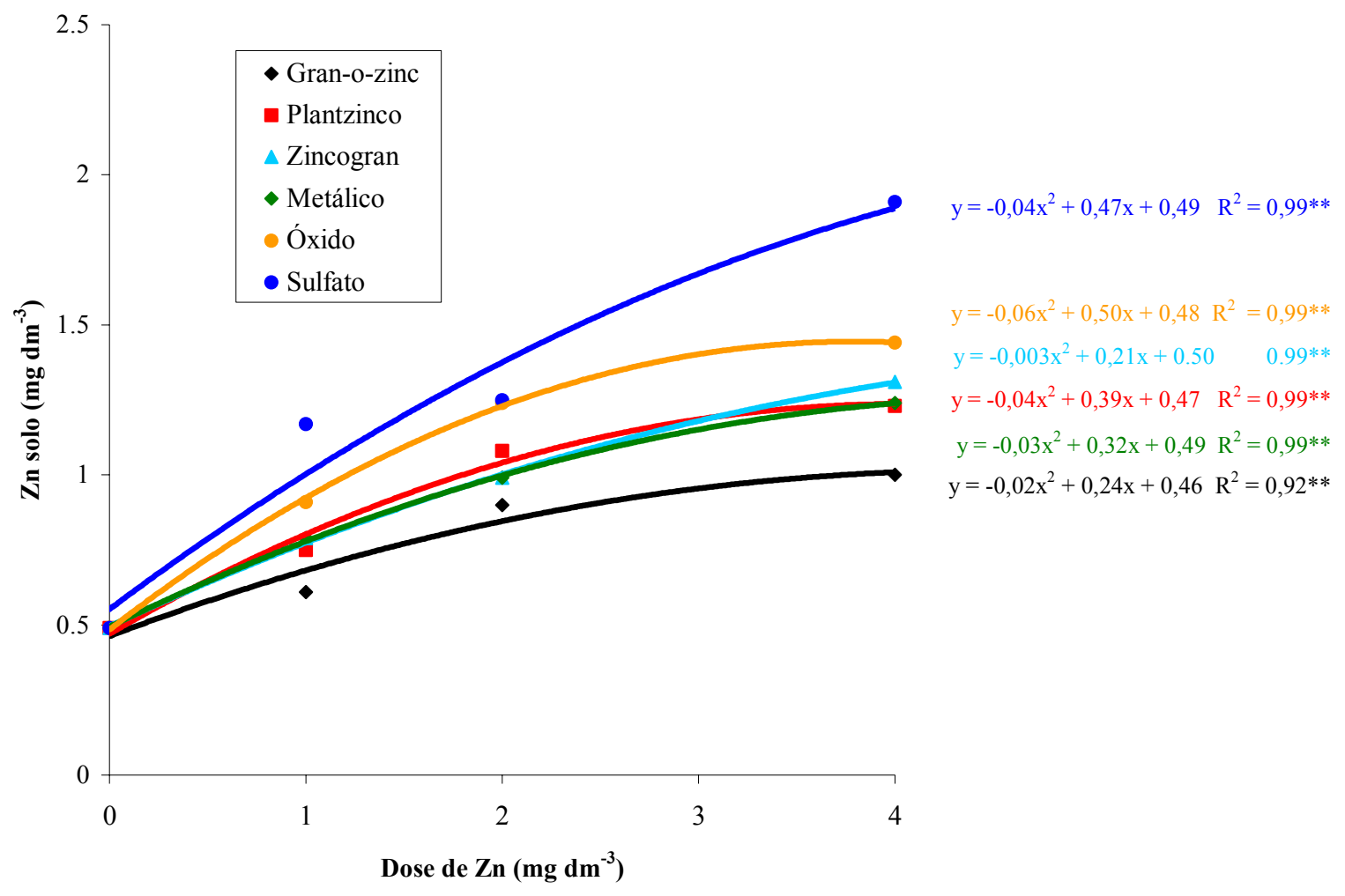

Figura 16 - Efeito das doses dentro do fator fontes, no teor de zinco residual no solo, em $\mathrm{mg} \mathrm{dm}{ }^{-3}$, solúvel em solução de DTPA.

Na Figura 17 observa-se o efeito residual das fontes de zinco na produção de matéria seca, em g vaso ${ }^{-1}$, pelas plantas de arroz. Apesar das diferenças dos valores encontrados terem sido pequenas, observou-se que o tratamento que recebeu óxido de zinco produziu mais matéria seca, enquanto que as piores fontes foram Gran-o-zinc e Zincogran, seguido pelo zinco metálico, produtos que apresentaram menor quantidade de zinco residual no solo após o primeiro cultivo de arroz.

O efeito quadrático das doses de zinco na produção de matéria seca, em $\mathrm{g} \mathrm{vaso}^{-1}$, pelas plantas de arroz, é apresentado na Figura 18. Observa-se que a quantidade de matéria seca produzida foi inferior à apresentada no primeiro corte, possivelmente 
devido à diminuição do teor de zinco no solo, retirado pelas primeiras plantas. A grande dispersão apresentada pelos pontos possivelmente influenciou a não significância da interação entre as fontes e doses testadas, na produção de matéria seca.

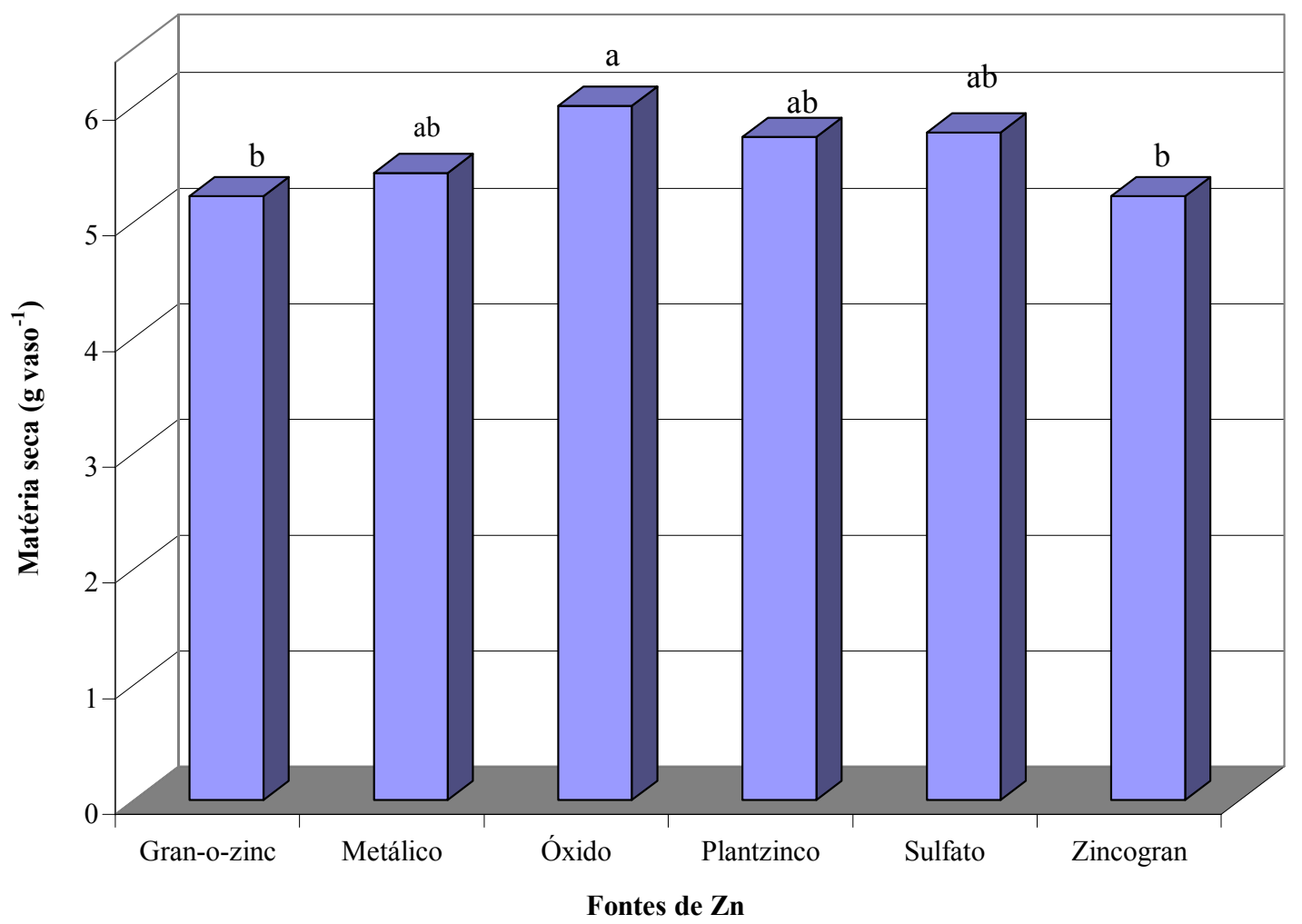

Figura 17 - Efeito residual das fontes de zinco na produção de matéria seca pelas plantas de arroz $-2^{\circ}$ cultivo (Médias com letras iguais não diferem à $1 \%$ ) 


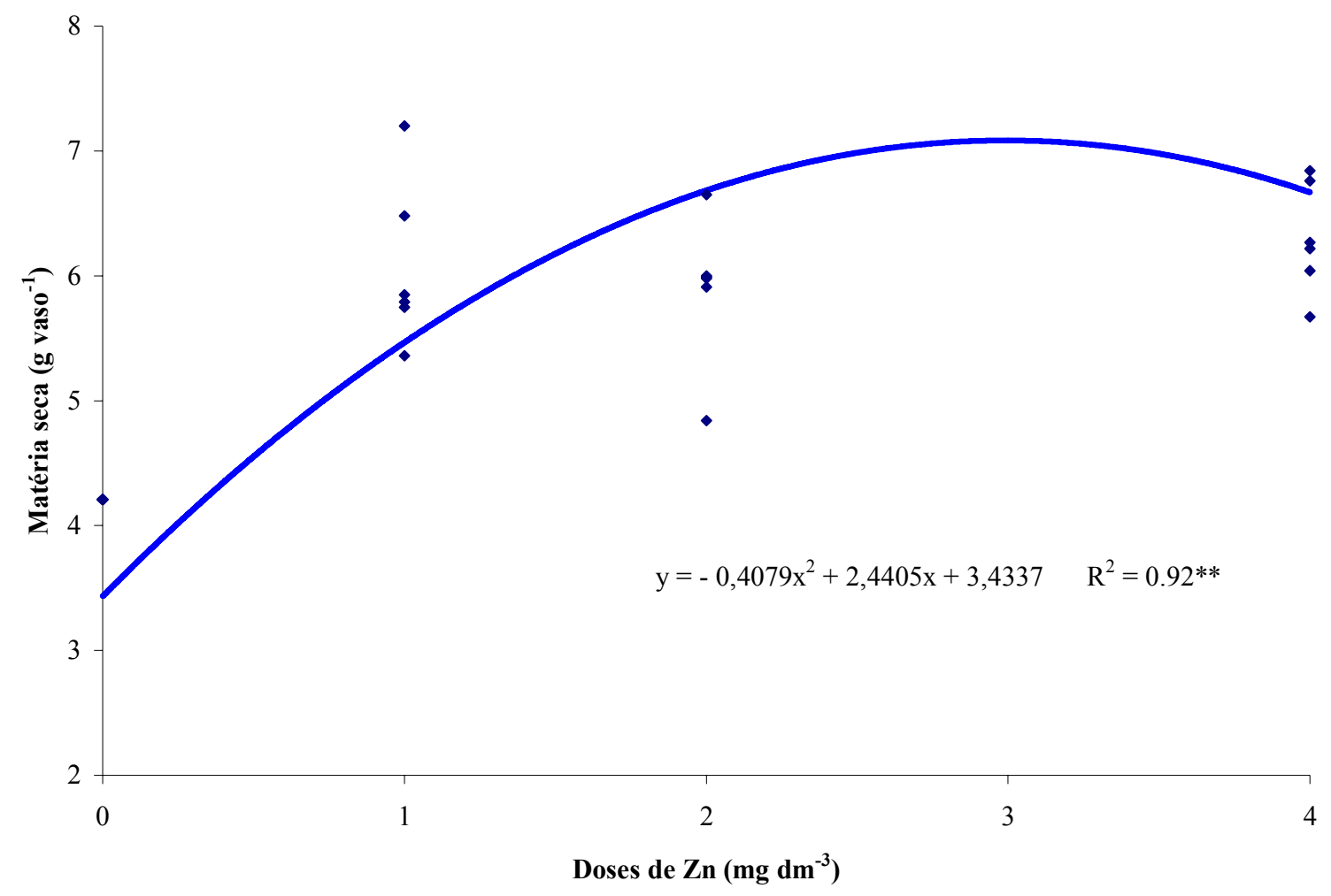

Figura 18 - Efeito residual das doses de zinco na produção de matéria seca, em g vaso ${ }^{-1}$, pelas plantas de arroz $-2^{\underline{0}}$ cultivo

\subsection{Teor de zinco nas plantas}

Somente houve efeito significativo isolado das fontes, à $5 \%$ de probabilidade (Prob. $>\mathrm{F}=0,01441$ ), e das doses de zinco (Prob. $>\mathrm{F}=0,00001$ ), no teor do elemento encontrado nas plantas de arroz no segundo cultivo.

$\mathrm{Na}$ Figura 19 encontra-se o efeito das fontes de zinco no teor do elemento, em $\mathrm{mg} \mathrm{kg}^{-1}$, nas plantas de arroz. Observa-se que as fontes sulfato e óxido foram as que novamente apresentaram teor superior do elemento em relação as demais, semelhante a primeiro cultivo. 
$\mathrm{O}$ efeito quadrático das doses de zinco no teor do elemento, em $\mathrm{mg} \mathrm{kg}^{-1}$, nas plantas de arroz encontra-se na Figura 20. Observa-se um efeito depressivo da dose $1 \mathrm{mg}$ $\mathrm{dm}^{-3}$ no teor de zinco nas plantas. Isto foi influenciado pelos teores baixos encontrados nos tratamentos com fertilizantes "fritas". Apesar de não ter ocorrido interação significativa entre fontes e doses de zinco, observou-se, nos tratamentos que receberam $4 \mathrm{mg} \mathrm{dm}^{-3}$ do elemento, um maior teor de zinco nas plantas que receberam como fontes o sulfato e o óxido de zinco, as fontes já demonstradas anteriormente como as de maior disponibilidade do elemento para as plantas.

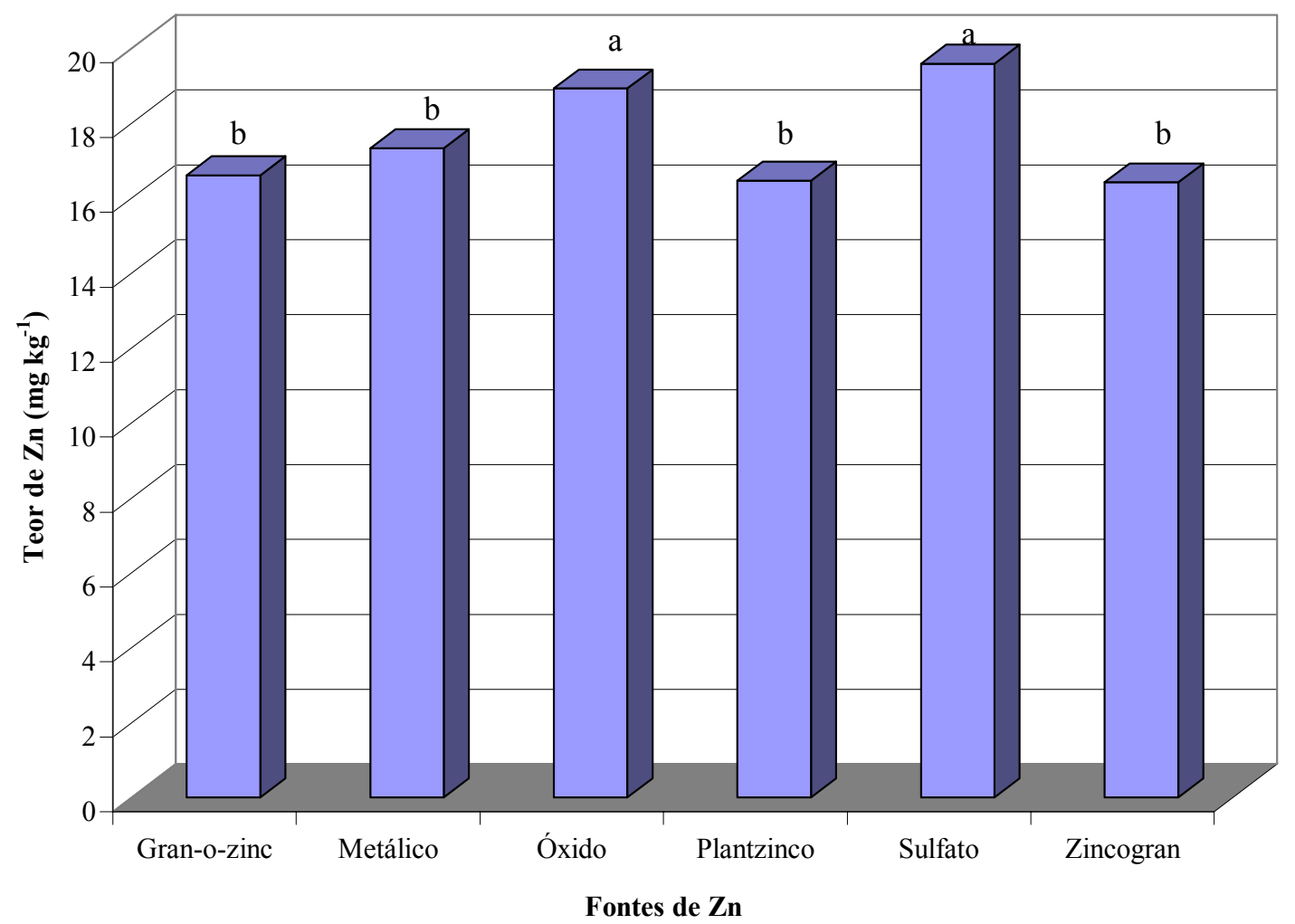

Figura 19 - Efeito residual das fontes de zinco no teor do elemento, em $\mathrm{mg} \mathrm{kg}^{-1}$, nas plantas de arroz $-2^{\underline{0}}$ cultivo (Médias com letras iguais não diferem à $5 \%$ ) 


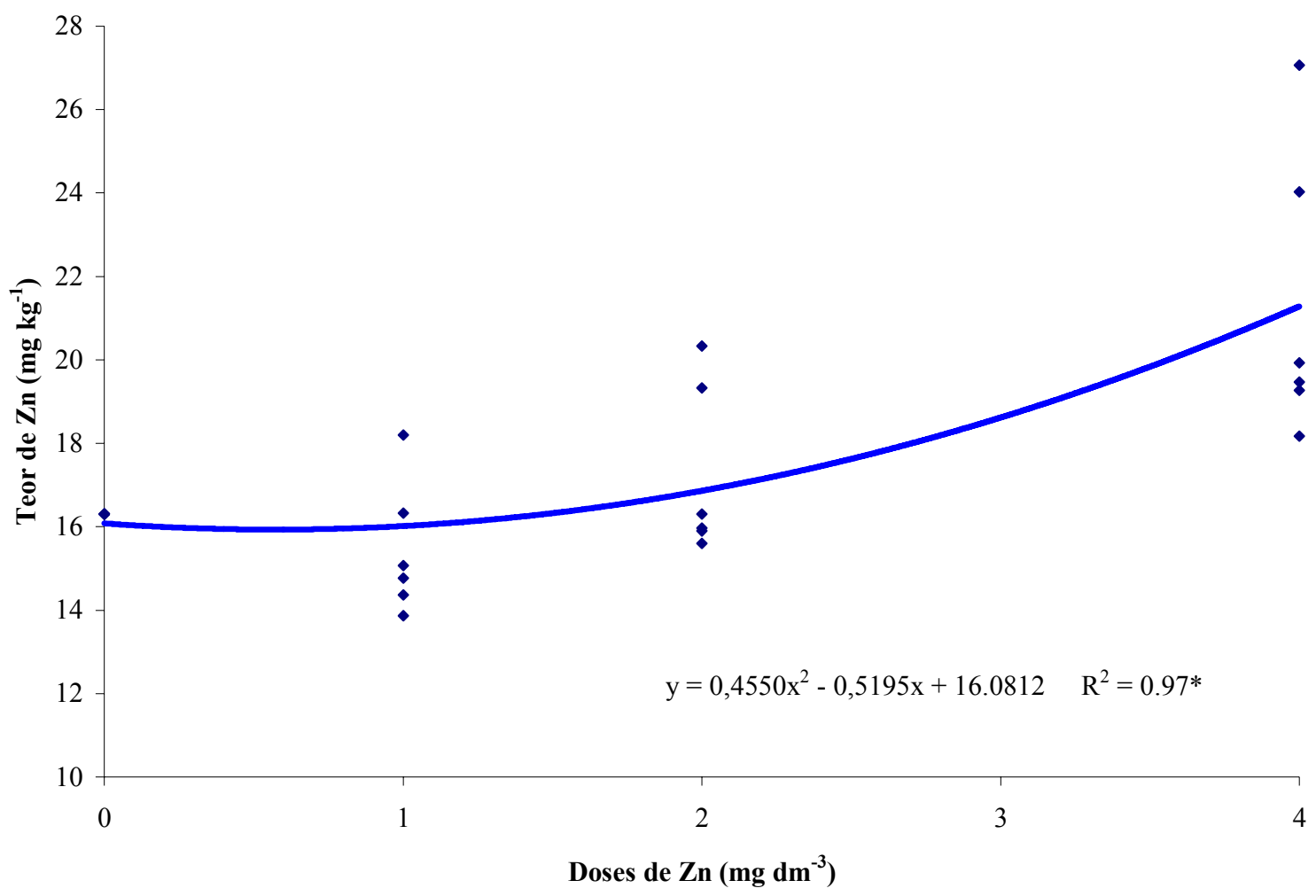

Figura 20 - Efeito residual das doses de zinco no teor do elemento, em $\mathrm{mg} \mathrm{kg}^{-1}$, nas plantas de arroz $-2^{-}$cultivo

\subsection{Conteúdo de zinco nas plantas}

Semelhante ao encontrado no primeiro cultivo, ocorreu interação significativa entre fontes e doses do elemento no conteúdo de zinco, em mg, nas plantas de arroz (Prob. $>\mathrm{F}=0,00587$ ).

$\mathrm{Na}$ Tabela 12 está indicado o efeito das fontes dentro do fator doses de zinco no conteúdo de zinco, em mg, encontrado nas plantas de arroz. Uma primeira observação é que o conteúdo de zinco nas plantas sob segundo cultivo foi inferior às do primeiro 
cultivo, pois a quantidade do elemento no solo estava inferior. Nas doses mais baixas não houve diferença significativa das fontes de zinco no fornecimento do elemento para as cultura. Já nas duas maiores doses, os tratamento que receberam os fertilizantes sulfato e óxido de zinco tiveram um maior conteúdo de zinco acumulado pelas plantas. Esse comportamento também foi observado para os valores médios absorvidos fornecidos por cada fonte do elemento. Novamente os produtos tipo "fritas" (Gran-ozinc, Plantzinco e Zincogran), mostraram-se inferiores no fornecimento do zinco às plantas. A forma química do zinco nestes três produtos mostra-se diferente, indicando a presença de formas de zinco não disponíveis às plantas, possivelmente pela solubilização parcial ocorrida na fabricação desses fertilizantes.

Quanto as regressões lineares para as doses de zinco dentro do fator fontes, apresentadas na Figura 21, observou-se um efeito linear entre a quantidade de zinco aplicada em cada tratamento e o conteúdo do elemento absorvido pelas plantas de arroz, com as fontes sulfato e óxido de zinco ainda apresentando maior disponibilidade do elemento, em comparação com as "fritas" e o zinco metálico.

Na Figura 22 observa-se a relação quadrática, altamente significativa, encontrada entre o teor de zinco residual no solo após o primeiro cultivo e o conteúdo de zinco nas plantas no segundo cultivo, mostrando ser o DTPA um bom extrator para avaliar o zinco disponível do solo, como citado por Bataglia \& Raij (1989) e Buzetti (1992).

Tabela 12 - Efeito residual das fontes dentro do fator doses, no conteúdo de zinco, em $\mathrm{mg}$, encontrado nas plantas de arroz - $2^{\underline{0}}$ cultivo.

\begin{tabular}{|c|c|c|c|c|c|}
\hline \multirow{2}{*}{ Fontes } & \multicolumn{4}{|c|}{ Doses de zinco $\left(\mathrm{mg} \mathrm{dm}^{-3}\right)$} & \multirow{2}{*}{ Média } \\
\hline & 0 & 1 & 2 & 4 & \\
\hline Gran-o-zinc & $0,052 \mathrm{a}$ & $0,083 \mathrm{a}$ & $0,090 \mathrm{~b}$ & $0,121 \mathrm{~b}$ & $0,086 \mathrm{~b}$ \\
\hline Plantzinco & $0,052 \mathrm{a}$ & $0,088 \mathrm{a}$ & $0,108 \mathrm{ab}$ & $0,130 \mathrm{~b}$ & $0,095 \mathrm{~b}$ \\
\hline Zincogran & $0,052 \mathrm{a}$ & $0,074 \mathrm{a}$ & $0,093 \mathrm{ab}$ & $0,126 \mathrm{~b}$ & $0,086 \mathrm{~b}$ \\
\hline Metálico & $0,052 \mathrm{a}$ & $0,104 \mathrm{a}$ & $0,099 \mathrm{ab}$ & $0,124 b$ & $0,095 \mathrm{~b}$ \\
\hline Óxido & $0,052 \mathrm{a}$ & $0,104 \mathrm{a}$ & $0,128 \mathrm{a}$ & $0,183 \mathrm{a}$ & $0,116 \mathrm{a}$ \\
\hline Sulfato & $0,052 \mathrm{a}$ & $0,106 \mathrm{a}$ & $0,128 \mathrm{a}$ & $0,183 \mathrm{a}$ & $0,117 \mathrm{a}$ \\
\hline Média & 0,052 & 0,093 & 0,108 & 0,144 & \\
\hline
\end{tabular}




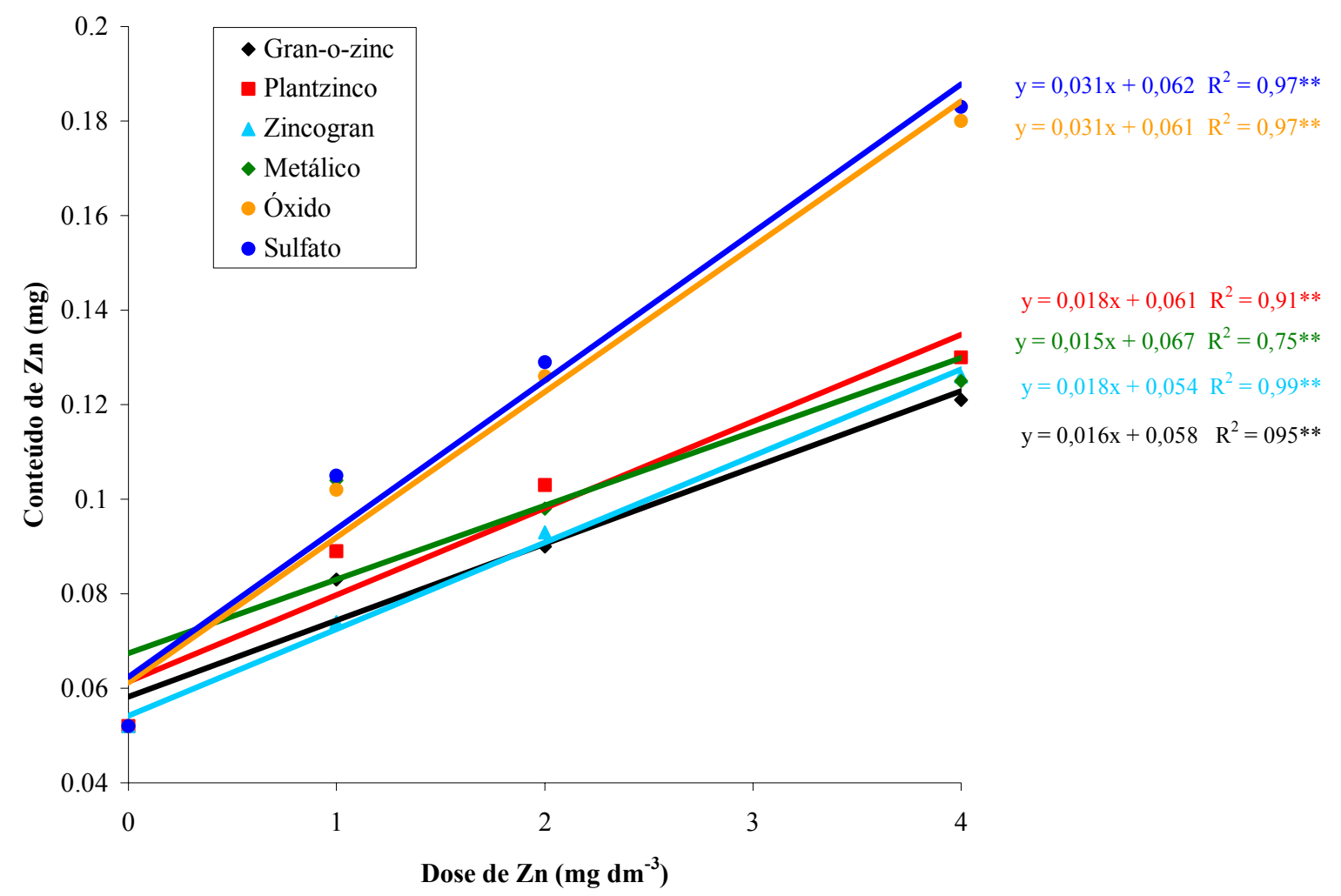

Figura 21 - Efeito das doses dentro do fator fontes, no conteúdo de zinco, em mg, encontrado nas plantas de arroz $-2^{\underline{o}}$ cultivo.

Os resultados encontrados para este experimento foram de grande importância, pois demonstraram uma eficiência diferenciada entre os produtos testados, isto é, o zinco contido nas fontes apresentaram disponibilidade diferenciada para as plantas de arroz. Foram utilizadas duas fontes reconhecidas como fertilizantes pela legislação, o sulfato e o óxido de zinco, que foram as que também apresentaram os melhores resultados de teor e conteúdo de zinco para as plantas. Já as "fritas", que são produtos comerciais, apresentaram uma disponibilidade do zinco inferior. Sabe-se que as "fritas" hoje comercializadas no Brasil não são realmente fritas, os micronutrientes não estão 
fundidos com silicatos, característica do produto (Alcarde \& Vale, 1999). São somente produtos obtidos da solubilização parcial com ácido súlfurico de resíduos metálicos, apresentando, portanto, micronutrientes na forma de sulfato, de boa disponibilidade, como demonstrado neste trabalho, e também micronutrientes na forma original que se encontravam no resíduo, de disponibilidade duvidosa. Por isso, sua garantia pelo teor total deve ser combatida, com a definição de um extrator que realmente solubilize somente o que a planta pode absorver.

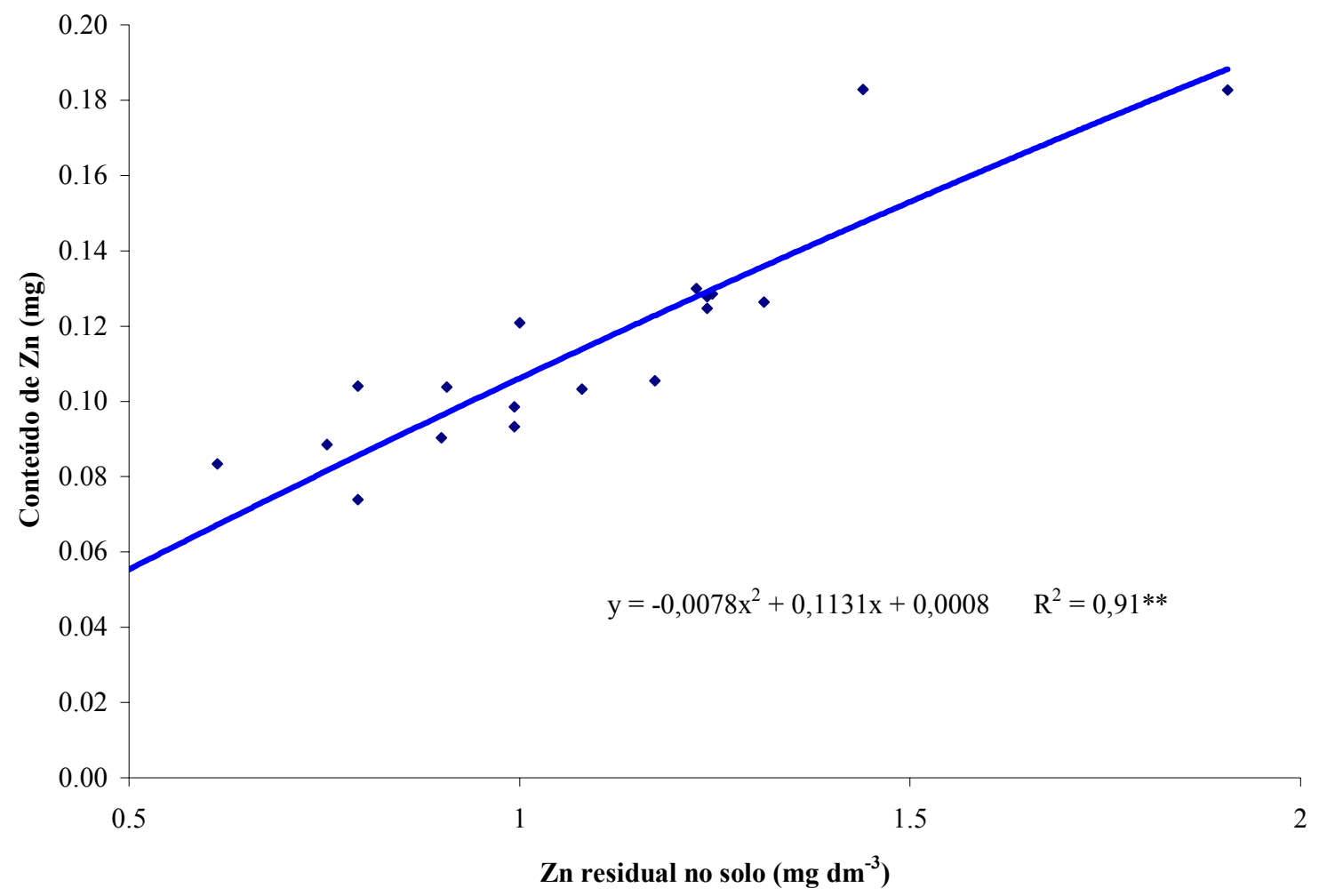

Figura 22 - Relação entre zinco residual no solo, solúvel em DTPA, após o primeiro cultivo e o conteúdo do elemento encontrado no segundo cultivo de arroz 


\subsubsection{Efeito das fontes e doses de zinco para a cultura do milho}

O objetivo deste segundo experimento com fontes de zinco foi buscar confirmações dos resultados obtidos com a cultura do arroz, pois a indicação foi realmente grande de que a disponibilidade do zinco em alguns fertilizantes é baixa para as plantas.

\subsubsection{Primeiro cultivo}

\subsection{Matéria seca}

Observou-se somente efeito significativo isolado das fontes e das doses de zinco, na produção de matéria seca, em g vaso ${ }^{-1}$, pelas plantas de milho (ambas com Prob.> F = $0,00001)$

Na Figura 23 encontra-se o efeito das fontes de zinco na produção de matéria seca. Observa-se que as menos eficientes foram as "fritas". A utilização do resíduo, apesar dele apresentar uma solubilidade nula em água, favoreceu uma maior produção de matéria seca em relação a esses produtos comerciais, o que pode ser explicado, possivelmente, pela sua solubilidade em torno de $80 \%$ em ácido cítrico e citrato neutro de amônio, por fervura, além da sua forma física original, pó muito fino, que pode ter facilitado sua solubilização e disponibilidade para as plantas; porém deve-se salientar que o produto FMM-100 também tinha essas características físicas, mas com solubilidade menor no ácido cítrico e citrato, e apresentou disponibilidade menor para as plantas.

Na Figura 24 observa-se o efeito quadrático das doses de zinco utilizadas, na produção de matéria seca. Apesar da não significância da interação fontes $\mathrm{x}$ doses, observou-se que, na prática, os tratamentos que receberam sulfato, óxido e resíduo apresentaram um melhor desenvolvimento vegetativo. A tendência de queda na matéria seca na maior dose utilizada foi uma influência de quanto foi obtido nos tratamentos que receberam "fritas". 


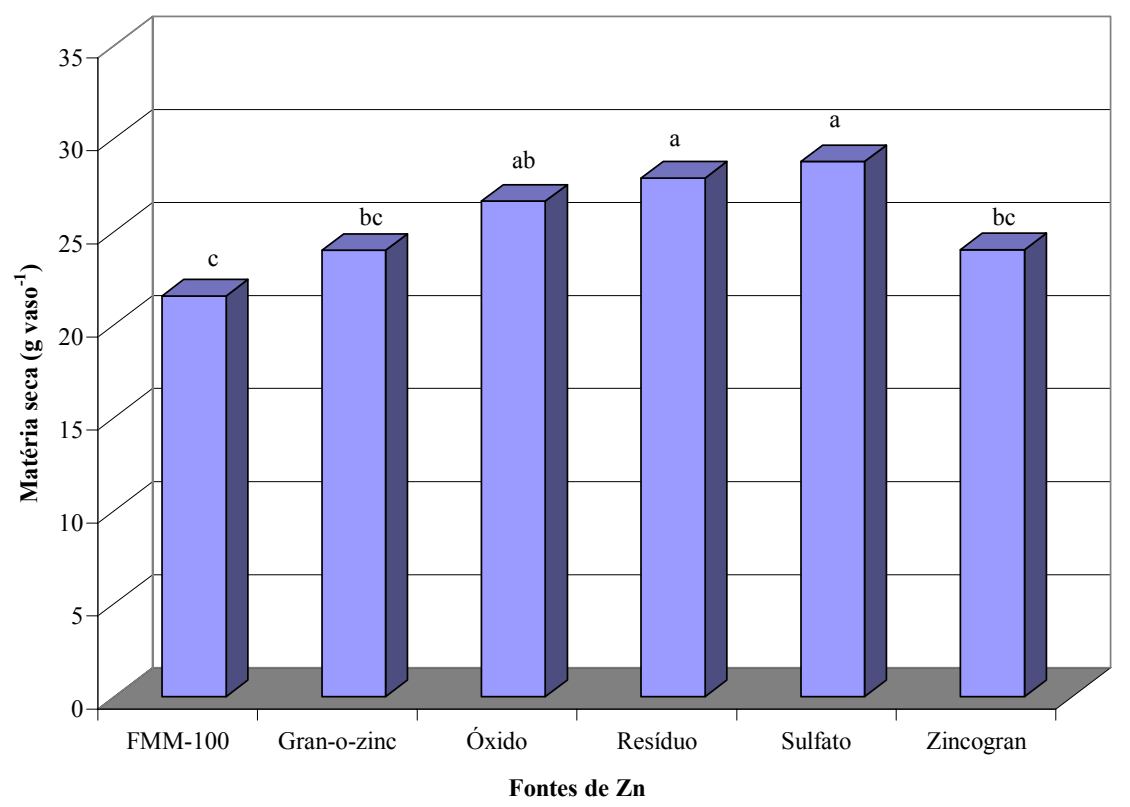

Figura 23 - Efeito das fontes de zinco na produção de matéria seca, em $\mathrm{g} \mathrm{kg}^{-1}$, pelas plantas de milho - $1^{\circ}$ cultivo (Médias com letras iguais não diferem à 1\%)

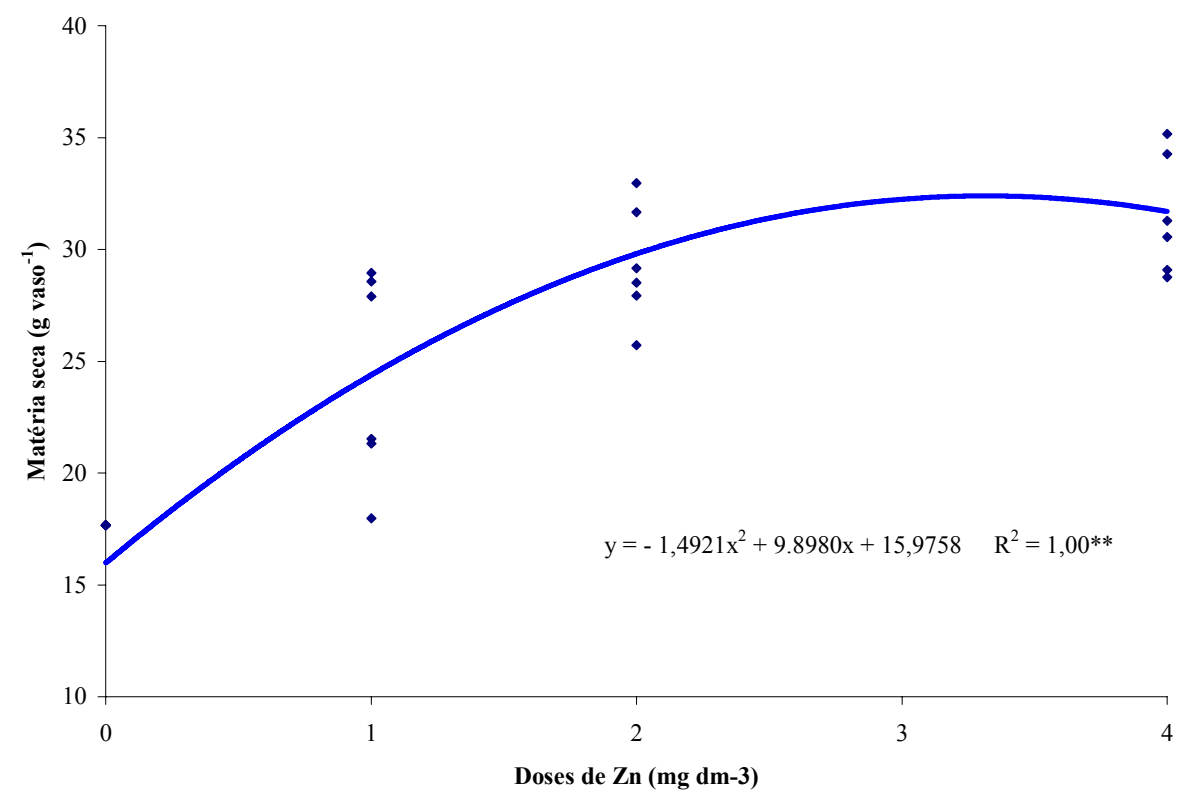

Figura 24 - Efeito das doses de zinco na produção de matéria seca, em g vaso ${ }^{-1}$, pelas plantas de milho $-1^{\underline{o}}$ cultivo 
$\mathrm{Na}$ Figura 25, observam-se detalhes de todos os tratamentos que receberam dose de $1 \mathrm{mg} \mathrm{dm}^{-3}$ do elemento, aos 50 dias após a germinação. As fontes "fritas" mostraram um menor desenvolvimento vegetativo, com alguns sintomas de deficiência de zinco sendo visualizados; também, as plantas sentiam maior stress por falta de água.

Sintomas típicos de deficiência de zinco, como encurtamento dos internódios e folhas novas pequenas, cloróticas e lanceoladas, foram encontradas nas plantas nos tratamentos que não receberam o elemento (Figura 26).

Figura 25 - Detalhes das plantas de milho, aos 50 dias após germinação, respectivamente nas doses 1 e $2 \mathrm{mg} \mathrm{dm}^{-3}$, evidenciando o menor desenvolvimento das plantas nos tratamentos que receberam "fritas" 
Figura 26 - Sintomas de deficiência de zinco no tratamento testemunha Acima: encurtamento dos internódios. Abaixo: sintomas nas folhas 


\subsection{Teor de zinco nas plantas}

$\mathrm{Na}$ avaliação do efeito das fontes e doses de zinco no teor do elemento, em mg $\mathrm{kg}^{-1}$, encontrado nas plantas de milho, observou-se que somente houve efeito significativo, ao nível de $1 \%$ de probabilidade, das doses do elemento adicionados aos tratamentos (Prob.> F = 0,00623). Na Figura 27 observa-se o efeito quadrático negativo das doses no teor de zinco nas plantas, isto é , aumentando-se a dose, diminuiu-se o teor nas plantas.

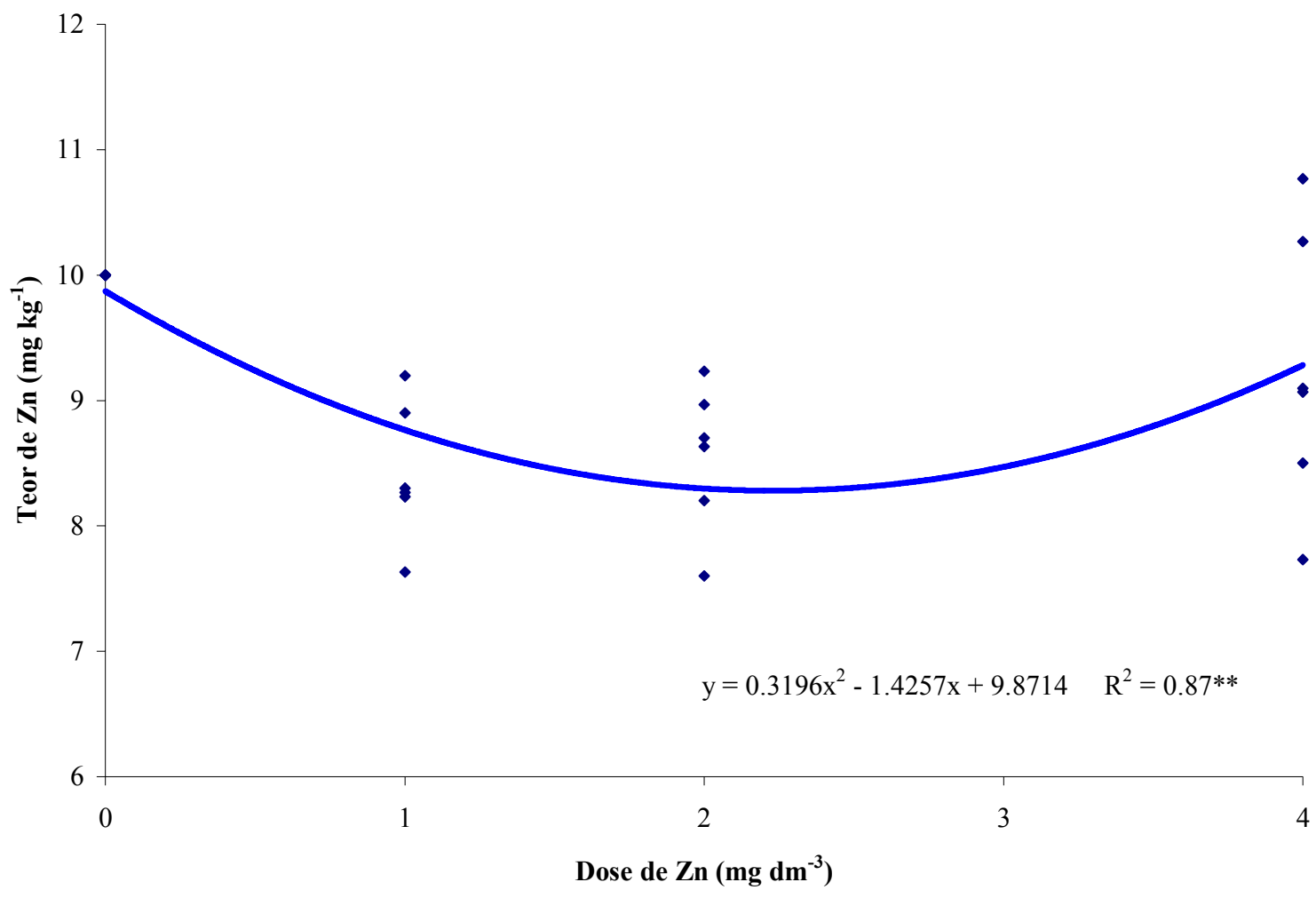

Figura 27 - Efeito das doses de zinco no teor do elemento, em $\mathrm{mg} \mathrm{kg}^{-1}$, nas plantas de milho $-1^{\underline{o}}$ cultivo 
$\mathrm{Na}$ verdade, o parâmetro teor não é um bom indicativo para avaliação da disponibilidade do micronutriente, pois somente indica a quantidade de nutrientes por massa de matéria seca. Observa-se que as plantas testemunha, que apresentaram uma baixa produção de matéria seca e deficiência de zinco, continham um teor do elemento entre os mais elevados. A tendência encontrada foi inversa à apresentada na avaliação de matéria seca (Figura 24), indicando que aumentando-se a matéria seca, diminui-se o teor de zinco nas plantas. Por isso é mais interessante considerar o conteúdo do micronutriente, pois este indica realmente quanto do elemento o fertilizante conseguiu suprir para as plantas.

\subsection{Conteúdo de zinco nas plantas}

Observou-se efeito significativo isolado das fontes (Prob. $>\mathrm{F}=0,00001$ ) e das doses (Prob. $>\mathrm{F}=0,00001$ ) no conteúdo de zinco, em mg, encontrado nas plantas de milho. Na Figura 28 encontra-se o efeito das fontes de zinco no conteúdo do elemento nas plantas. Observou-se, novamente, que as plantas que receberam os produtos sulfato, óxido e resíduo, apresentaram um maior acúmulo do elemento. $\mathrm{O}$ zinco contido nas "fritas" mostrou-se menos disponível às plantas, semelhante ao que já foi encontrado para a cultura do arroz, comprovando a necessidade de se avaliar mais corretamente a disponibilidade do zinco contido nos fertilizantes. É interessante salientar que nem a forma física inicial das "fritas" influenciou na disponibilidade, pois os produtos Gran-ozinc e Zincogran foram coletadas na forma granulada, enquanto o FMM-100 era um pó fino. Deve-se salientar, ainda, que todos os produtos foram aplicados na forma de pó nos vasos. Esse resultado difere do encontrado por Mortvedt (1992), que concluiu que a disponibilidade do zinco nos produtos moídos é semelhante, independente da solubilidade em água. 


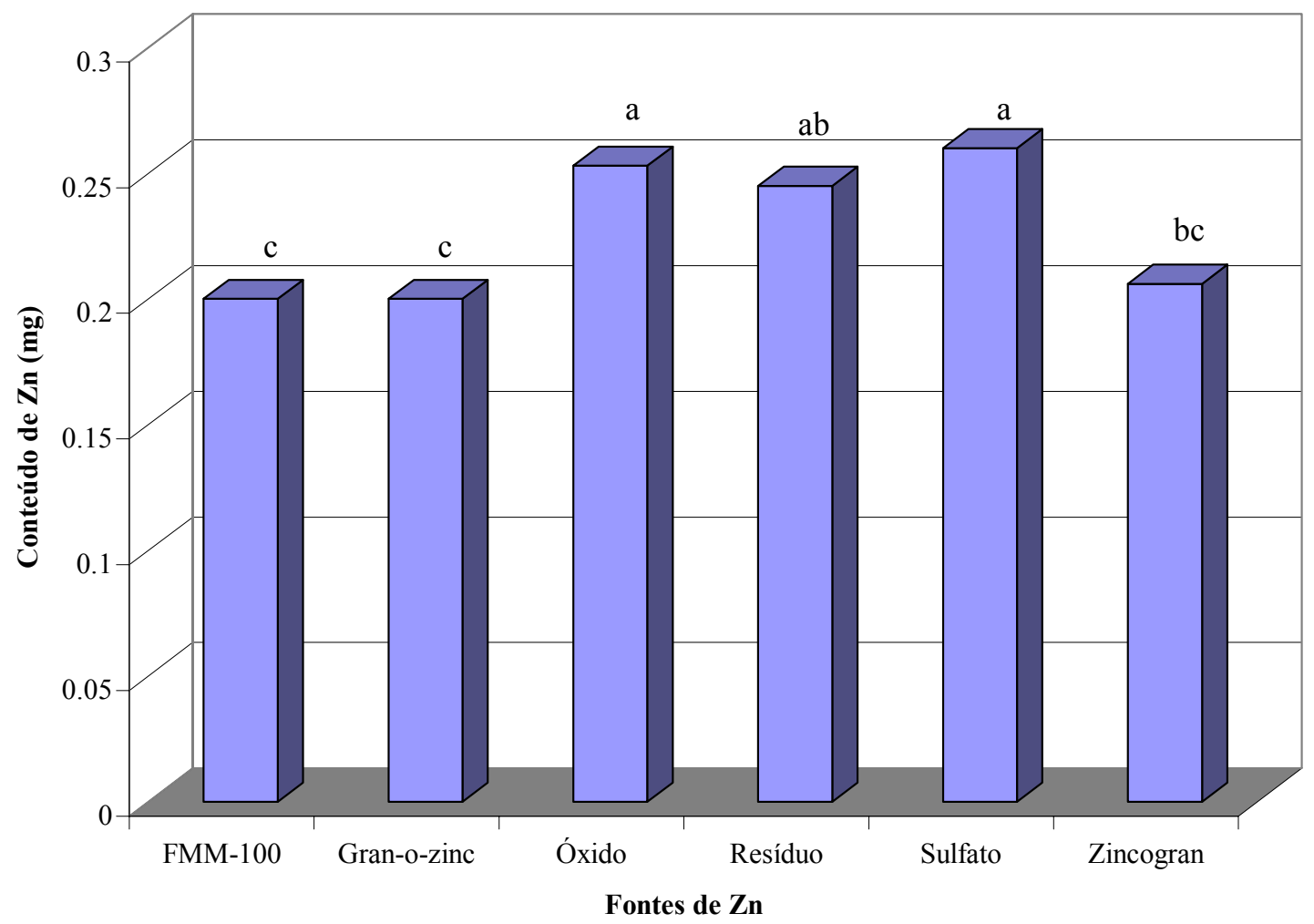

Figura 28 - Efeito das fontes de zinco no conteúdo do elemento, em mg, encontrado nas plantas de milho $-1^{\underline{0}}$ cultivo (Médias com letras iguais não diferem à $1 \%$ )

Na Figura 29 encontra-se o efeito das doses de zinco aplicadas, no conteúdo do elemento, em mg, nas plantas de milho. Observou-se um efeito quadrático positivo, com aumento do conteúdo em função do aumento das doses. Apesar de não ter ocorrido significância da interação fontes $\mathrm{x}$ doses, os tratamentos que receberam sulfato, óxido e resíduo apresentaram maior quantidade de zinco nas plantas do que as que receberam "fritas", comportamento semelhante ao encontrado para o parâmetro matéria seca. 


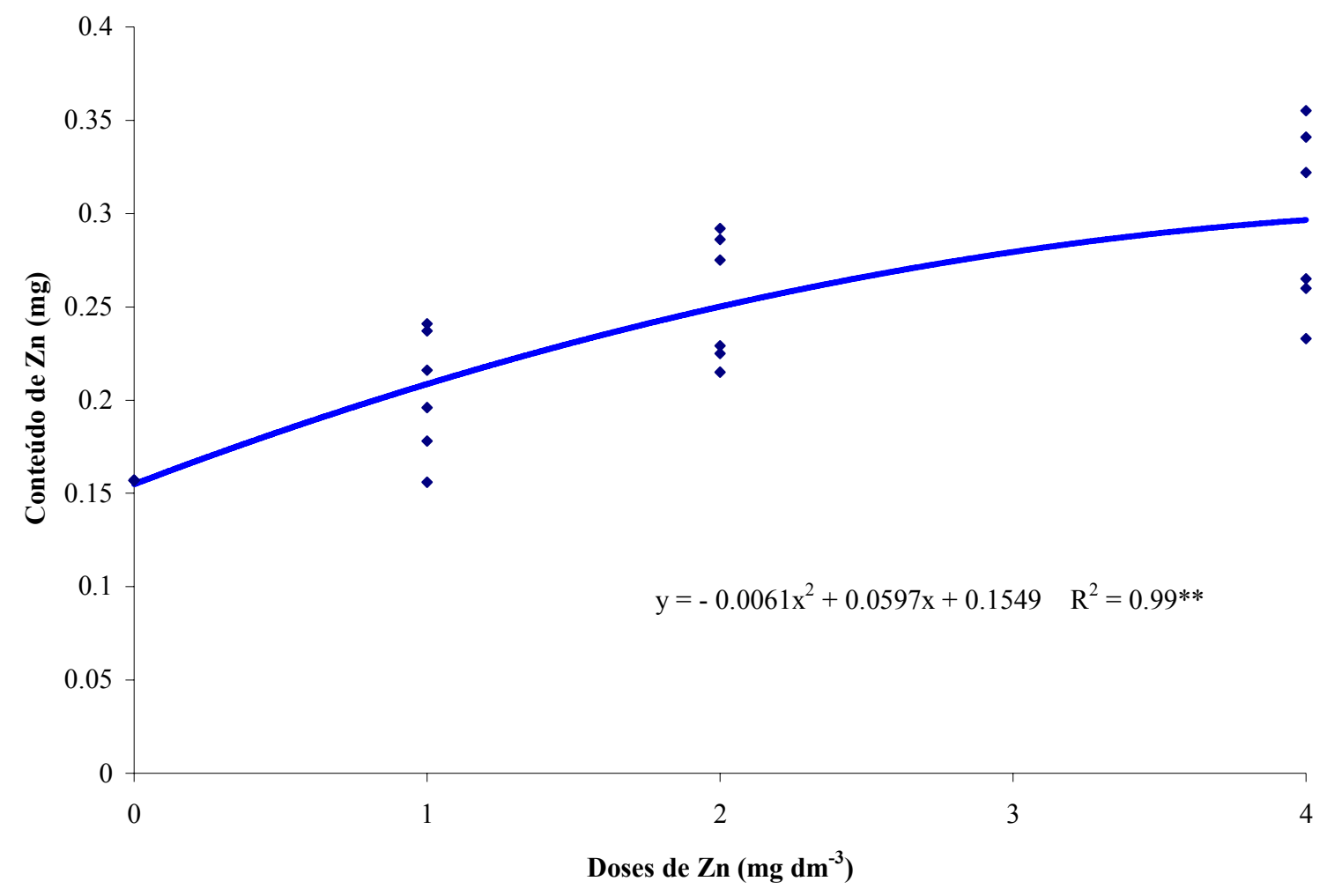

Figura 29 - Efeito das doses de zinco no conteúdo do elemento, em mg, encontrado nas plantas de milho $-1^{\underline{o}}$ cultivo

\subsubsection{Teor de zinco residual no solo}

$\mathrm{Na}$ avaliação deste parâmetro observou-se efeito significativo da interação fontes $\mathrm{x}$ doses de zinco (Prob. $>\mathrm{F}=0,00001)$. Na Tabela 13 encontra-se o efeito das fontes dentro do fator doses, no teor de zinco residual no solo, em $\mathrm{mg} \mathrm{dm}^{-3}$, solúvel em solução de DTPA. Observou-se que a fonte sulfato é a que apresentou a maior quantidade de zinco residual no solo, em todas as doses estudadas, seguido pelo resíduo e pelo óxido de zinco. Novamente as "fritas" foram as fontes menos eficiente ou com menor teor residual. Entre essas três fontes, o FMM-100 foi a que apresentou a 
maior quantidade de zinco residual no solo. Malavolta et al. (1987) encontraram maior residual no solo do zinco de um sulfato de zinco em relação de um óxido e uma frita.

Tabela 13 - Efeito das fontes dentro do fator doses, no teor de zinco residual no solo, em $\mathrm{mg} \mathrm{dm}{ }^{-3}$, solúvel em solução de DTPA.

\begin{tabular}{|c|c|c|c|c|c|}
\hline \multirow{2}{*}{ Fontes } & \multicolumn{4}{|c|}{ Doses de zinco $\left(\mathrm{mg} \mathrm{dm}^{-3}\right)$} & \multirow{2}{*}{ Média } \\
\hline & 0 & 1 & 2 & 4 & \\
\hline FMM - 100 & 0360 a & $0680 \mathrm{ah}$ & 0773 c & $1666 \mathrm{~cd}$ & 0870 c \\
\hline Gran-o-zinc & $0.360 \mathrm{a}$ & $0.473 \mathrm{~b}$ & $0.693 \mathrm{c}$ & $1346 \mathrm{e}$ & $0.718 \mathrm{~d}$ \\
\hline Zincogran & $0,360 \mathrm{a}$ & $0,667 \mathrm{ab}$ & $0,753 \mathrm{c}$ & $1,496 \mathrm{de}$ & $0,819 \mathrm{~cd}$ \\
\hline Resíduo & $0,360 \mathrm{a}$ & $0,660 \mathrm{ab}$ & $0,973 \mathrm{~b}$ & $2,113 \mathrm{~b}$ & $1,026 \mathrm{~b}$ \\
\hline Óxido & $0,360 \mathrm{a}$ & $0,686 \mathrm{ab}$ & $0,980 \mathrm{~b}$ & $1,900 \mathrm{bc}$ & $0,957 \mathrm{~b}$ \\
\hline Sulfato & $0,360 \mathrm{a}$ & $0,840 \mathrm{a}$ & $1,533 \mathrm{a}$ & $2,433 \mathrm{a}$ & $1,292 \mathrm{a}$ \\
\hline Média & 0,360 & 0,667 & 0,934 & 1,825 & \\
\hline
\end{tabular}

Médias seguidas de mesmas letras indicam resultados semelhantes pelo Teste de Tukey à $1 \%$

Comparação nas colunas

Média de três repetições

Na Figura 30 encontra-se o efeito linear das doses dentro do fator fontes, no teor de zinco residual no solo, em $\mathrm{mg} \mathrm{dm}^{-3}$, solúvel em solução de DTPA, evidenciando ainda mais a maior disponibilidade do sulfato, seguido do resíduo, óxido e "fritas".

\subsubsection{Segundo cultivo}

\subsection{Matéria seca}

Diferente do que foi encontrado no primeiro cultivo, foi observado apenas o efeito significativo das doses de zinco aplicadas (Prob.> F $=0,00001$ ), na produção de matéria seca, em g vaso ${ }^{-1}$, pelas plantas de milho. Porém, as plantas que cresceram no tratamento sem adicionar zinco apresentaram, como esperado, os mesmos sintomas de deficiência do elemento já citados anteriormente.

Na Figura 31 encontra-se o efeito das doses de zinco na produção de matéria seca no segundo cultivo de milho. Pode ser observado que, com exceção do tratamento 
testemunha, houve um efeito muito pequeno do zinco no solo na produção de matéria seca, apesar das diferenças de zinco residual no solo entre ao fontes utilizadas

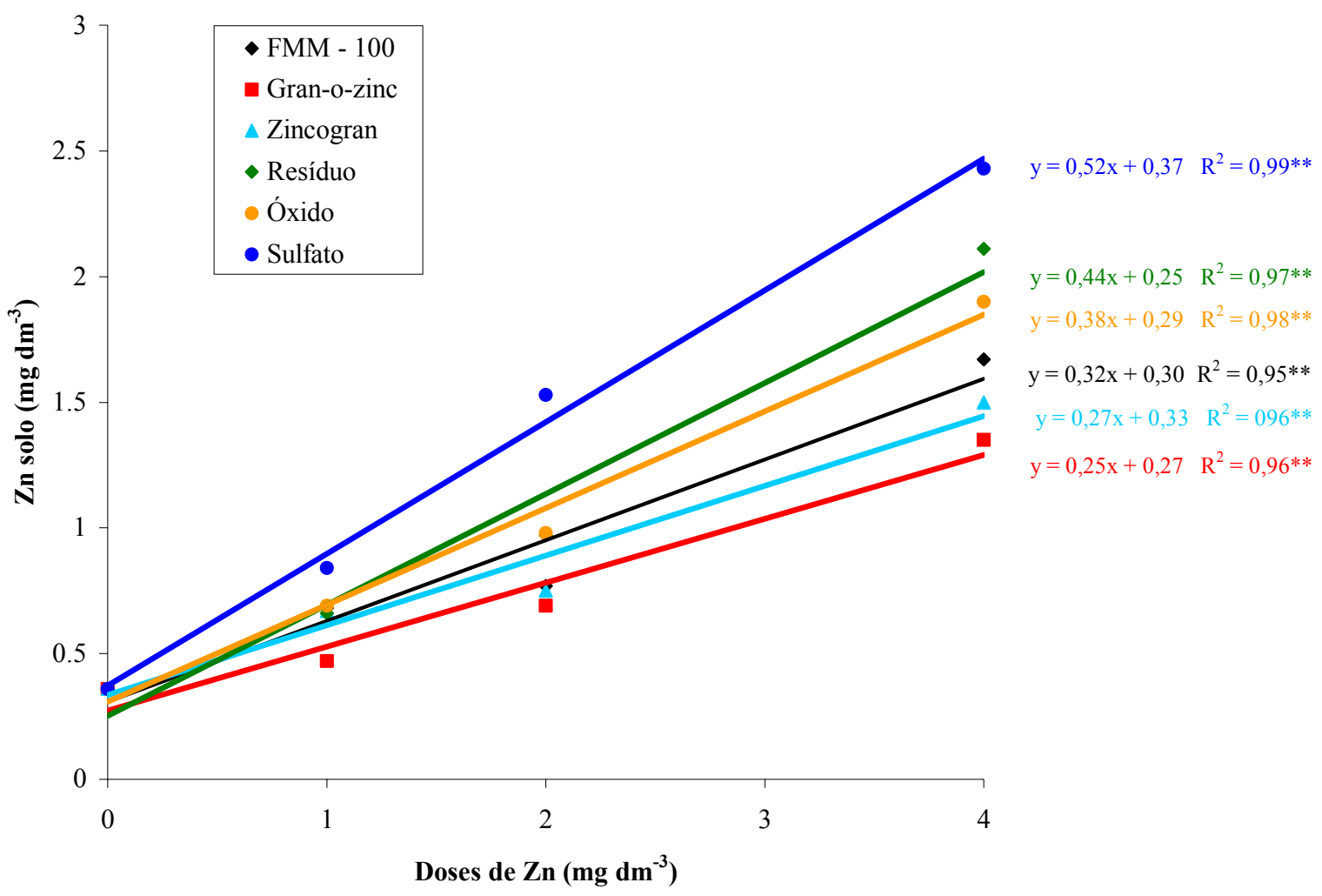

Figura 30 - Efeito das doses dentro do fator fontes, no teor de zinco residual no solo, em $\mathrm{mg} \mathrm{dm}{ }^{-3}$, solúvel em solução de DTPA. 


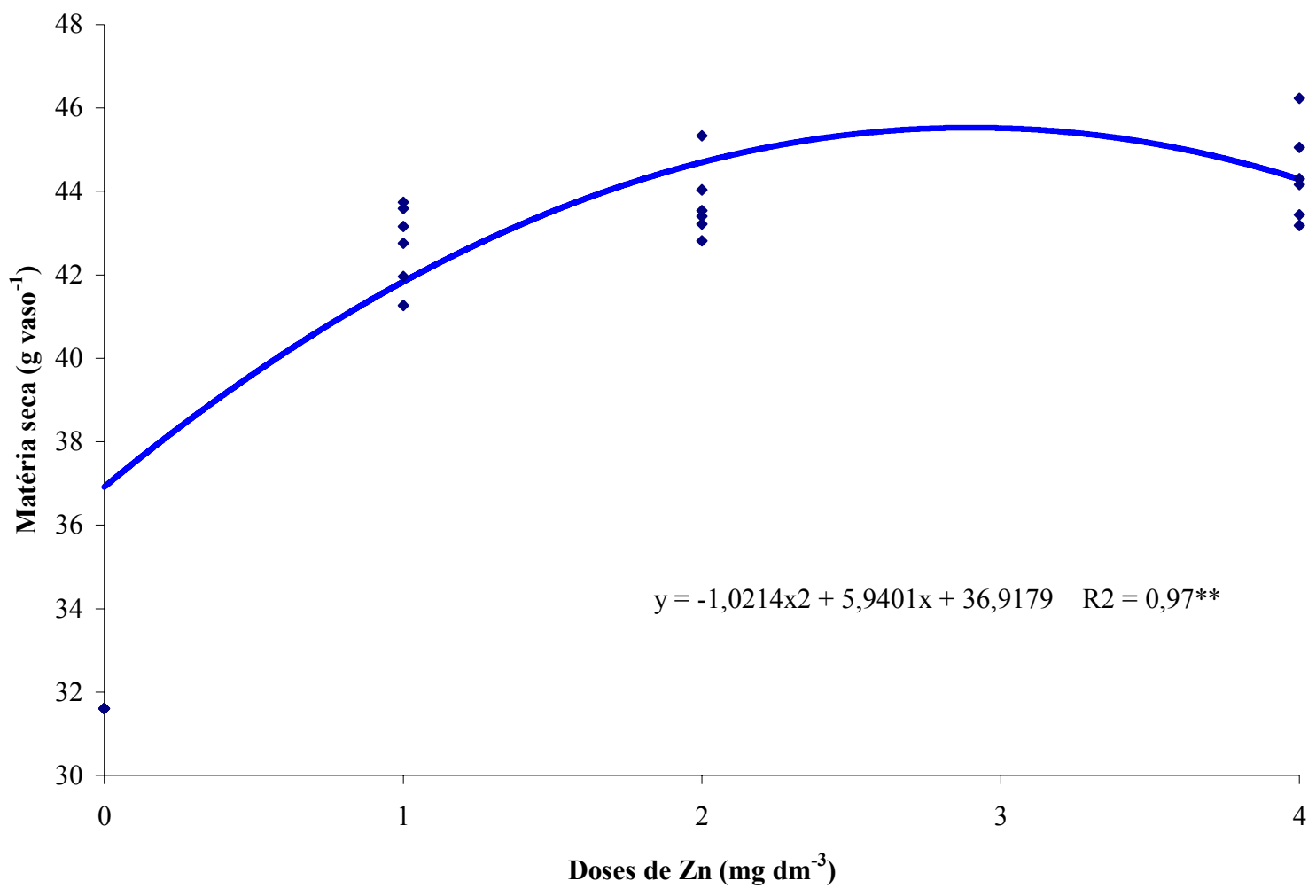

Figura 31 - Efeito residual das doses de zinco na produção de matéria seca, em g vaso ${ }^{-1}$, pelas plantas de milho $-2^{\underline{o}}$ cultivo.

\subsection{Teor de zinco nas plantas}

$\mathrm{Na}$ avaliação do efeito residual das fontes e doses de zinco no teor do elemento, em $\mathrm{mg} \mathrm{kg}^{-1}$, encontrado nas plantas de milho, no segundo cultivo observou-se, diferentemente do primeiro cultivo, efeito significativo da interação fontes $x$ doses, à $5 \%$ de probabilidade (Prob.> F = 0,01262). Na Tabela 14 encontra-se ao efeito das fontes dentro do fator doses, no teor de zinco nas plantas, onde observa-se um comportamento semelhante na análise de todos os parâmetros anteriores, isto é, uma maior capacidade da fonte sulfato em fornecer zinco para as plantas, seguido do resíduo e óxido, com as fontes "fritas" mostrando-se inferiores. 
Tabela 14 - Efeito das fontes dentro do fator doses, no teor de zinco, em $\mathrm{mg} \mathrm{kg}^{-1}$, encontrado nas plantas de milho $-2^{\underline{0}}$ cultivo.

\begin{tabular}{|c|c|c|c|c|c|}
\hline \multirow{2}{*}{ Fontes } & \multicolumn{4}{|c|}{ Doses de zinco $\left(\mathrm{mg} \mathrm{dm}^{-3}\right)$} & \multirow{2}{*}{ Média } \\
\hline & 0 & 1 & 2 & 4 & \\
\hline FMM -100 & $8,07 \mathrm{a}$ & $9,10 \mathrm{ab}$ & $10,57 \mathrm{a}$ & $11,43 \mathrm{~b}$ & $9,79 \mathrm{bc}$ \\
\hline Gran-o-zinc & $8,07 \mathrm{a}$ & $7,90 \mathrm{~b}$ & $7,97 \mathrm{~b}$ & $13,07 \mathrm{ab}$ & $9,25 \mathrm{c}$ \\
\hline Zincogran & $8,07 \mathrm{a}$ & $8,77 \mathrm{ab}$ & $10,53 \mathrm{a}$ & $11,73 \mathrm{ab}$ & $9,77 \mathrm{bc}$ \\
\hline Resíduo & $8,07 \mathrm{a}$ & $10,93 \mathrm{a}$ & $10,00 \mathrm{ab}$ & $13,90 \mathrm{ab}$ & $10,72 \mathrm{ab}$ \\
\hline Óxido & $8,07 \mathrm{a}$ & $9,40 \mathrm{ab}$ & $11,43 \mathrm{a}$ & $13,53 \mathrm{ab}$ & $10,60 \mathrm{ab}$ \\
\hline Sulfato & $8,07 \mathrm{a}$ & $11,03 \mathrm{a}$ & $12,13 \mathrm{a}$ & $15,03 \mathrm{a}$ & $11,57 \mathrm{a}$ \\
\hline Média & 8,07 & 9,52 & 10,44 & 13,11 & \\
\hline
\end{tabular}

$\mathrm{O}$ efeito das doses dentro do fator fontes, no teor de zinco, em $\mathrm{mg} \mathrm{kg}^{-1}$, encontrado nas plantas de milho no segundo cultivo está indicado na Figura 32, evidenciando, novamente, a maior disponibilidade do sulfato, resíduo e óxido.

\subsection{Conteúdo de zinco nas plantas}

Houve significância ao nível de 5\% da interação fontes $\mathrm{x}$ doses de zinco, no conteúdo de zinco, em mg, nas plantas de milho no segundo corte (Prob.> $F=0,01028$ ). $\mathrm{Na}$ Tabela 15 observa-se o efeito das fontes dentro do fator doses, no conteúdo de zinco nas plantas. Os resultados mostraram, novamente, a menor disponibilidade das fontes FMM-100, Gran-o-zinc e Zincogran, produtos comerciais, indicando o uso de subprodutos industriais solubilizados parcialmente com ácido sulfúrico. 


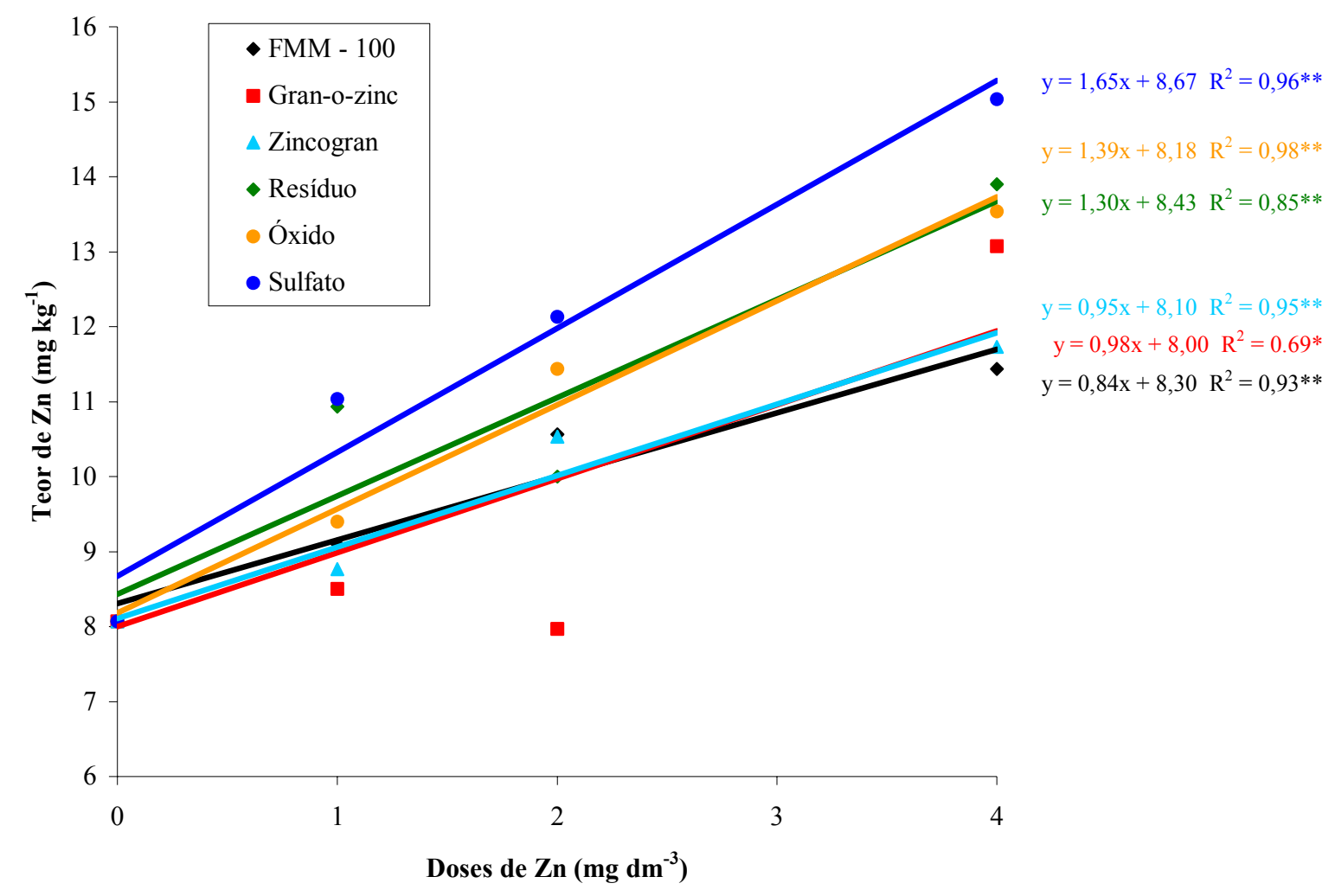

Figura 32 - Efeito das doses dentro do fator fontes no teor de zinco, em $\mathrm{mg} \mathrm{kg}^{-1}$, encontrado nas plantas de milho $-2^{\underline{0}}$ cultivo.

Tabela 15 - Efeito das fontes dentro do fator doses, no conteúdo de zinco, em mg, encontrado nas plantas de milho $-2^{\underline{0}}$ cultivo.

\begin{tabular}{|c|c|c|c|c|c|}
\hline \multirow{2}{*}{ Fontes } & \multicolumn{4}{|c|}{ Doses de zinco $\left(\mathrm{mg} \mathrm{dm}^{-3}\right)$} & \multirow{2}{*}{ Média } \\
\hline & 0 & 1 & 2 & 4 & \\
\hline FMM -100 & $0,295 \mathrm{a}$ & $0,389 \mathrm{ab}$ & $0,456 \mathrm{a}$ & $0,496 \mathrm{c}$ & $0,409 \mathrm{bc}$ \\
\hline Gran-o-zinc & $0,295 \mathrm{a}$ & $0,325 \mathrm{~b}$ & $0,344 \mathrm{~b}$ & $0,562 \mathrm{abc}$ & $0,382 \mathrm{c}$ \\
\hline Zincogran & $0,295 \mathrm{a}$ & $0,377 \mathrm{ab}$ & 0,469 a & $0,543 \mathrm{bc}$ & $0,421 b c$ \\
\hline Resíduo & $0,295 \mathrm{a}$ & $0,462 \mathrm{a}$ & $0,443 a b$ & $0,616 \mathrm{ab}$ & $0,454 \mathrm{ab}$ \\
\hline Óxido & $0,295 \mathrm{a}$ & $0,411 \mathrm{ab}$ & $0,518 \mathrm{a}$ & $0,609 a b$ & $0,458 \mathrm{ab}$ \\
\hline Sulfato & $0,295 \mathrm{a}$ & $0,471 \mathrm{a}$ & $0,528 \mathrm{a}$ & $0,664 \mathrm{a}$ & $0,490 \mathrm{a}$ \\
\hline Média & 0,295 & 0,406 & 0,460 & 0,582 & \\
\hline
\end{tabular}

Médias seguidas de mesmas letras indicam resultados semelhantes pelo Teste de Tukey à 5\% Comparação nas colunas

Média de três repetições 
O efeito das doses dentro do fator fontes no acúmulo de zinco pelas plantas novamente mostrou a maior disponibilidade do elemento contido no sulfato, seguido pelo óxido e resíduo, conforme se observa na Figura 33.

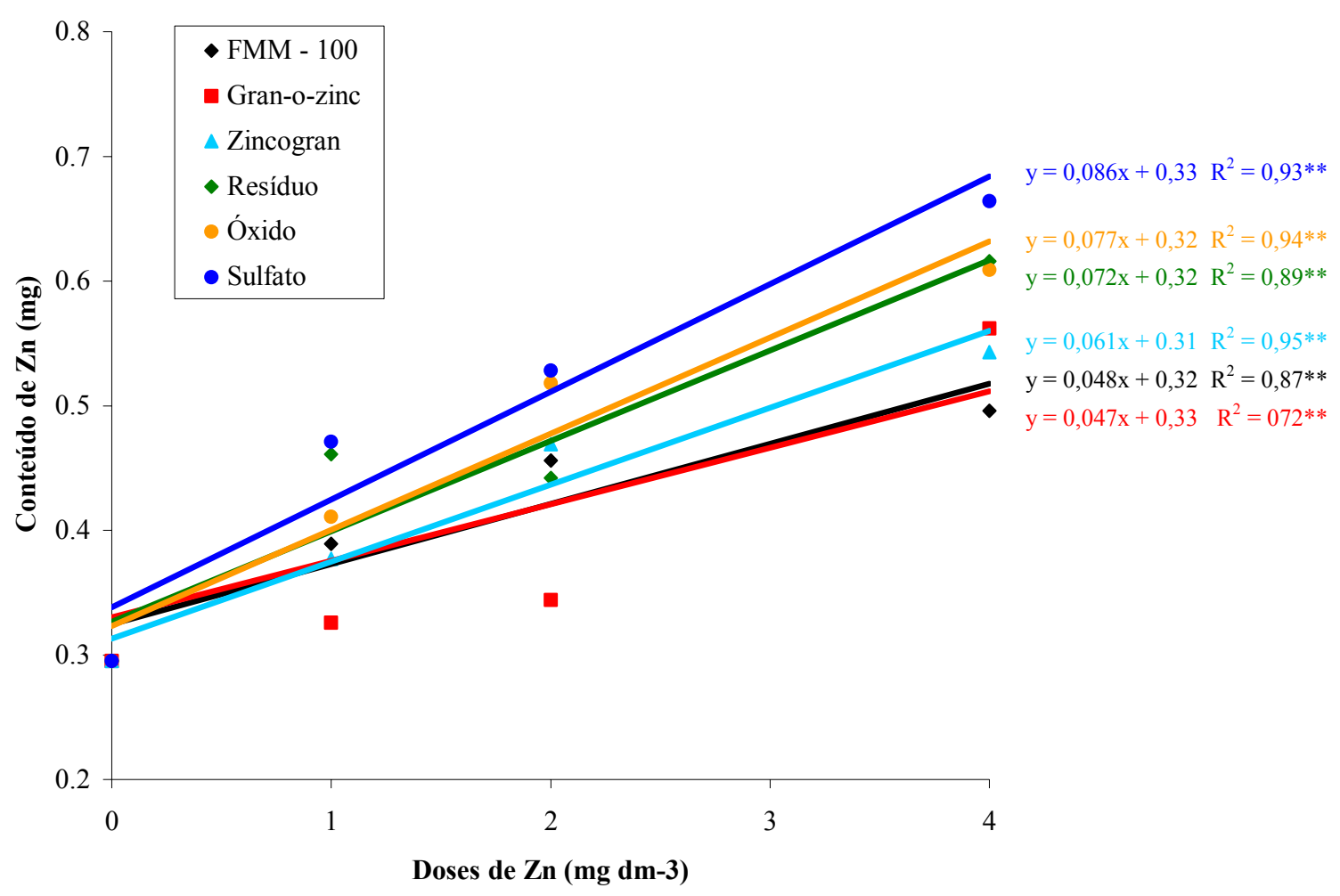

Figura 33 - Efeito das doses dentro do fator fontes no conteúdo de zinco, em $\mathrm{mg} \mathrm{kg}^{-1}$, encontrado nas plantas de milho $-2^{\underline{o}}$ cultivo.

Na Figura 34 observa-se a relação quadrática, altamente significativa, encontrada entre o teor de zinco residual no solo, após o primeiro cultivo, e o conteúdo de zinco nas plantas, no segundo cultivo, mostrando ser o DTPA um bom extrator para avaliar o zinco disponível do solo, como citado por Bataglia \& Raij (1989) e Buzetti (1992). 


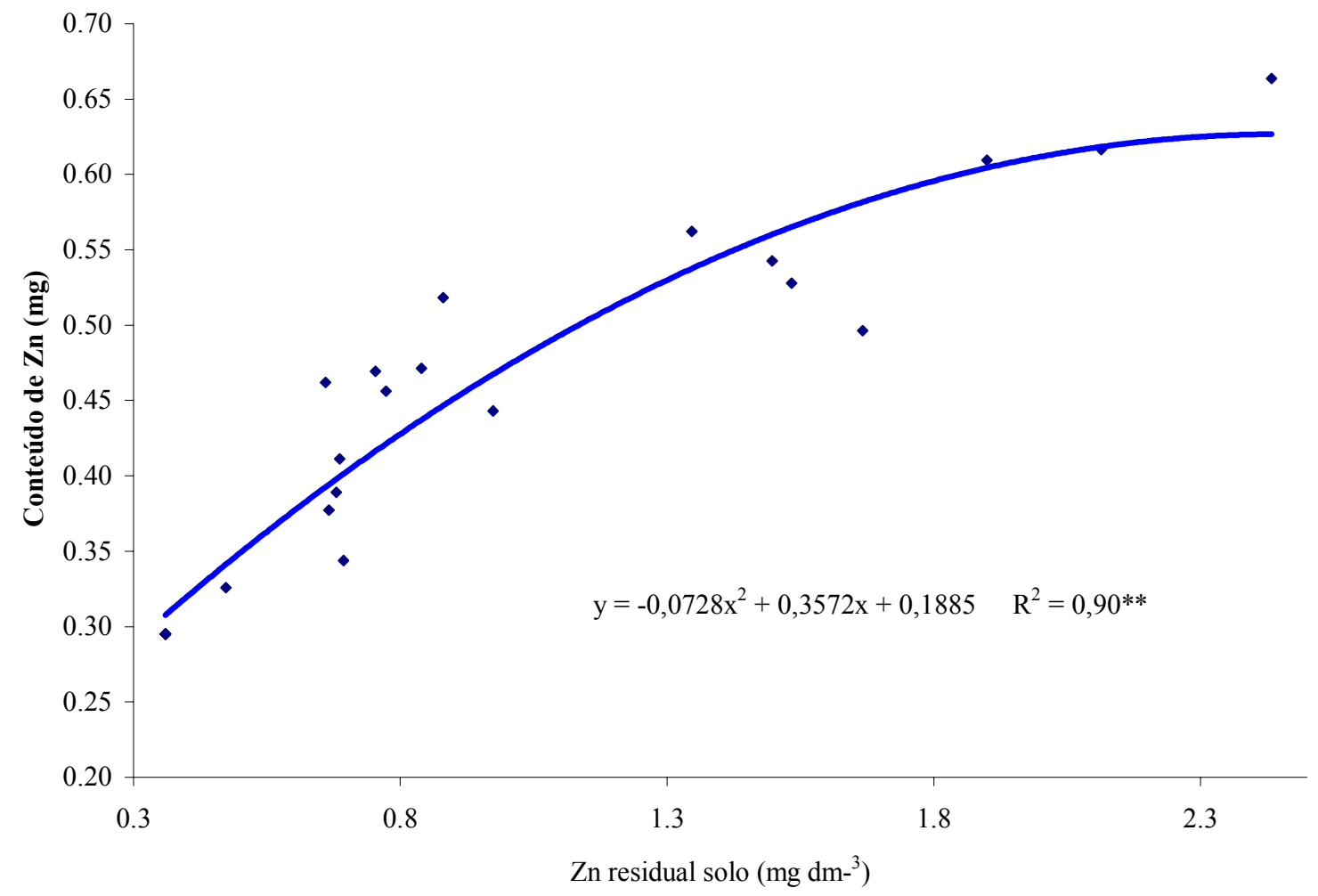

Figura 34 - Relação entre zinco residual no solo, solúvel em DTPA, após o primeiro cultivo, e o conteúdo do elemento encontrado nas plantas de milho, segundo cultivo

Os resultados obtidos com a cultura do milho foram semelhantes aos encontrados para o arroz, isto é, boa disponibilidade das fontes sulfato e óxido de zinco em relação às "fritas". As duas primeiras fontes foram aplicadas sob a forma P.A., por isso existia a certeza de que a forma do zinco contida nos produtos estava realmente nas formas sulfato e óxido. Já as "fritas" são produtos amostrados no mercado, da maneira como são comercializados. Não se sabe realmente em quais formas químicas o zinco está neste produto. Porém, o que se pode concluir, é que a garantia do zinco contido nestes produtos não pode ser feita pelo teor total, como vem sendo realizado, pois o aproveitamento do elemento nele contidos não será completo. E isto toma uma grande importância quando se observa o grande uso dessas fontes no preparo de formulações 
com micronutrientes pelas indústrias granuladoras e misturadoras de grânulos. Em vista de todos os resultados encontrados, cresce a importância da definição de um novo extrator para se definir a disponibilidade do zinco, assim como provavelmente dos outros micronutrientes metálicos nos fertilizantes, como proposto por Vale \& Alcarde (1999). Os resultados encontrados com o resíduo utilizado para a cultura do milho foi acima do esperado. Porém não se conhece a origem deste resíduo, bem como se foi ou não acidulada. O produto estava em forma de pó muito fino e, segundo Mortvedt (1992), a disponibilidade do elemento em produtos com essa forma é adequada, independente da solubilidade em água. Porém, isto não foi encontrado para o FMM-100, que também estava na forma pó.

\subsection{Avaliação da disponibilidade do boro e zinco contido nos fertilizantes}

\subsubsection{Boro}

$\mathrm{Na}$ Tabela 16 encontram-se os coeficientes de correlação lineares entre a solubilidade nos diversos extratores de boro contido nos fertilizantes com o acúmulo de boro encontrado nas plantas de soja no primeiro cultivo.

Tabela 16 - Coeficientes de correlação lineares obtidos entre a solubilidade nos extratores de boro nos fertilizantes e o acúmulo pelas plantas de soja no primeiro cultivo

\begin{tabular}{lc}
\hline \multicolumn{1}{c}{ Extrator } & $\mathrm{r}$ \\
\hline Teor total & $0,93 * *$ \\
Água & $0,73 * *$ \\
Água quente & $0,89 * *$ \\
Ácido cítrico agitação & $0,92 * *$ \\
Ácido cítrico fervura & $0,93 * *$ \\
Citrato neutro de amônio agitação & $0,89 * *$ \\
Citrato neutro de amônio fervura & $0,93 * *$ \\
DTPA & $0,82 * *$ \\
\hline
\end{tabular}

** significativo à $1 \%$ de probabilidade 
Os resultados obtidos indicam que a garantia do boro nos fertilizantes pelo teor total, conforme exige a legislação de fertilizantes, é válida. Esses resultados são semelhantes aos encontrados por Vale \& Alcarde (1999), realizando testes em placas de Petri. Na presente avaliação foram utilizadas três fontes reconhecidas como fertilizantes (ácido bórico, ulexita e colemanita) e três "fritas" comerciais (Borogran, Gran-o-bor e MIB-4). A disponibilidade das três primeiras é de certa maneira reconhecida pelo meio agronômico. Quanto as três últimas, em sua fabricação devem ter sido utilizadas matérias-primas reconhecidas como fertilizantes, muito possivelmente uma ulexita, até uma colemanita. Isto ocorre porque não existe uma fonte alternativa de boro para os fertilizantes; por ser um elemento não metálico, o boro não está contido em nenhum subproduto industrial. Daí, o comportamento semelhante entre as fontes.

Também observou-se que outros extratores podem ser utilizados para se definir a disponibilidade do boro nos fertilizantes, principalmente o ácido cítrico e o citrato neutro de amônio, ambos na relação 1:100 e sob fervura por cinco minutos. Na Tabela 6 observou-se que esses dois extratores solubilizaram o boro dos fertilizantes semelhante ao teor total. Dependendo do extrator que for definido para avaliar a disponibilidade dos micronutrientes, pode-se pensar na utilização de um desses, visando se trabalhar somente com um extrator para todos os micronutrientes, muito importante para os laboratórios de análise de rotina de fertilizantes.

\subsubsection{Zinco}

$\mathrm{Na}$ Tabela 17 encontram-se os coeficientes de correlação lineares entre a solubilidade nos diversos extratores de zinco contido nos fertilizantes, com o acúmulo de zinco encontrado nas plantas de arroz e milho, no primeiro cultivo. Observa-se que os resultados foram bastante diferentes daqueles encontrados para o boro. Porém os resultados foram semelhantes para as duas culturas. A avaliação pelo teor total não é a que indica a melhor disponibilidade para as plantas, porém é a que vem sendo usada na 
rotina pelos laboratórios. $\mathrm{O}$ extrator que se mostrou melhor para ambos os casos foi o citrato neutro de amônio, na relação 1:100 e com fervura por cinco minutos.

Tabela 17 - Coeficientes de correlação lineares obtidos entre a solubilidade nos extratores de zinco nos fertilizantes e o acúmulo pelas plantas de arroz e milho, no primeiro cultivo

\begin{tabular}{lcc}
\hline \multirow{2}{*}{ Extrator } & \multicolumn{2}{c}{$\mathrm{r}$} \\
\cline { 2 - 3 } & Arroz & Milho \\
\hline Teor total & $0,82^{* *}$ & $0,82^{* *}$ \\
Água & $0,65^{* *}$ & $0,56^{* *}$ \\
Ácido cítrico agitação & $0,88^{* *}$ & $0,90^{* *}$ \\
Ácido cítrico fervura & $0,81^{* *}$ & $0,71^{* *}$ \\
Citrato neutro de amônio agitação & $0,92^{* *}$ & $0,89^{* *}$ \\
Citrato neutro de amônio fervura & $0,92^{* *}$ & $0,96^{* *}$ \\
DTPA & $0,73^{* *}$ & $0,64^{* *}$ \\
\hline
\end{tabular}

** significativo à $1 \%$ de probabilidade

Outro parâmetro interessante para se comparar a solubilização pelos extratores e o conteúdo médio nas plantas é o Índice de Eficiência Agronômico (IEA) das fontes em relação ao sulfato, indicado na Tabela 18.

Tabela 18 - Índice de Eficiência Agronômica para as fontes de zinco utilizadas, em relação ao sulfato de zinco, na dose $4 \mathrm{mg} \mathrm{dm}^{-3}$,

\begin{tabular}{ccc}
\hline \multirow{2}{*}{ Fonte } & \multicolumn{2}{c}{ Índice de Eficiência Agronômica } \\
\cline { 2 - 3 } & Arroz & Milho \\
\cline { 2 - 3 } & 100 & 100 \\
Sulfato & 85 & 93 \\
Óxido & 43 & 45 \\
Gran-o-zinc & 48 & - \\
Plantzinco & 38 & 47 \\
Zincogran & - & 45 \\
FMM - 100 & 49 & - \\
Metálico & - & 83 \\
Resíduo & &
\end{tabular}

IEA $=\frac{\text { Conteúdo }_{\text {fonte }}-\text { Conteúdo testemunha }}{\text { Conteúdo }}$ 
A solubilização dos produtos utilizados como fertilizantes no citrato neutro de amônio, sob fervura (Tabela 8) foi bem semelhante ao que aconteceu no cultivo das culturas: foi solubilizado todo o zinco do sulfato, em torno de $90 \%$ do óxido e, em média de $50 \%$ para as "fritas", e $80 \%$ do resíduo. O zinco metálico teve um comportamento diferenciado, mas isso reflete pouco, pois ele não é utilizado nas adubações nesta forma. Também, a solubilização do FMM-100 pelo citrato subestimou parte do zinco disponível para as plantas, mas em escala menor que o metálico. Neste tipo de estudo alguns casos normalmente tendem a surgir. Por isso as avaliações não devem parar.

Pelos resultados gerais, pode-se concluir que o citrato neutro de amônio, na relação 1:100 e sob fervura por cinco minutos, é um bom extrator para se avaliar a disponibilidade do zinco nos fertilizantes. Porém os estudos devem continuar, pois o assunto não está esgotado. Experimentos em campo podem ser requeridos para se aproximar mais da realidade, também a utilização de outras fontes com zinco, além da avaliação dos outros micronutrientes metálicos são necessários. Mas a conclusão de que a avaliação pelo teor total não é válida já é uma realidade. Portanto, a adoção imediata da solução de citrato neutro de amônio, diluição $(1+9)$, com agitação por uma hora, ou com fervura por cinco minutos, na relação 1:100, contribuirá, de forma significativa, para aumentar a eficiência das adubações com zinco e também fortalecer a idoneidade de setor de fertilizantes, em especial o de micronutrientes. 


\section{CONCLUSÕES}

Os fertilizantes com boro apresentaram solubilidade em água diferenciadas, porém semelhantes em soluções de ácido cítrico $20 \mathrm{~g} \mathrm{~L}^{-1}$ e citrato neutro de amônio (1+9), ambos com fervura por cinco minutos. Também, a solubilização por esses dois extratores foi semelhante ao teor total.

Todos os produtos com boro apresentaram disponibilidade semelhante para as plantas de soja. Isso mostra que, apesar de cada produto possuir uma forma química diferente, no solo estas formas são todas disponíveis às plantas.

Como conseqüência, a garantia pelo teor total mostrou-se boa para o elemento. Também a garantia pelo teor solúvel em soluções de ácido cítrico $20 \mathrm{~g} \mathrm{~L}^{-1}$ ou citrato neutro de amônio (1+9), ambos na relação 1:100 e com fervura por cinco minutos, pode ser indicada para caracterizar o boro disponível nos fertilizantes.

Já os produtos contendo zinco apresentaram solubilidades diferenciadas em cada extrator, e todos os extratores tiveram comportamento diferente do método de determinação do teor total.

Quanto a disponibilidade para as plantas, observou-se que o zinco presente no sulfato de zinco é mais disponível às plantas, seguido daquele contido no óxido de zinco, enquanto as "fritas" apresentaram menor disponibilidade. O índice de eficiência agronômica, em relação ao sulfato de zinco, foi próximo de $90 \%$ para o óxido de zinco, e de $50 \%$ para as fritas.

O extrator que apresentou solubilização mais próxima desses valores e, por conseqüência, maior coeficiente de correlação com o que a planta absorveu, foi o citrato neutro de amônio (1+9), na relação 1:100 e com fervura por cinco minutos. 
A adoção imediata desse extrator contribuirá, de forma significativa, para aumentar a eficiência das adubações com zinco e também fortalecer a idoneidade de setor de fertilizantes, em especial o de micronutrientes. 


\section{REFERÊNCIAS BIBLIOGRÁFICAS}

ABREU, C.A. de; ABREU, M.F. de; RAIJ, B. van; BATAGLIA, O.C.; ANDRADE, J.C. Extraction of boron from soil by microwave for ICP-AES determination. Communication in Soil Science and Plant Analysis, v.25, p.3321-3333, 1994.

ALCARDE, J.C.; PONCHIO, C.O. A ação solubilizante das soluções de citrato de amônio e de ácido cítrico sobre fertilizantes fosfatados. Revista Brasileira de Ciência do Solo, v.3, p. 173-178, 1979.

ALCARDE, J.C.; RODELLA, A.A.. Caracterização de fertilizantes simples contendo zinco. Scientia Agrícola, v. 50, n.1, p. 121-126, 1993.

ALCARDE, J.C.; VALE, F. Avaliação química de fertilizantes com micronutrientes comercializados no Brasil (compact disc). In: CONGRESO LATINOAMERICANO DE LA CIENCIA DEL SUElO, 14., Pucon - Chile, 1999. ClaCS 99. Temuco: Universidade de La Frontera, 1999.

AMARAL, R.D. Avaliação de um resíduo da indústria de zinco como corretivo da acidez e fertilizante do solo e fonte de metais pesados para as plantas. Viçosa, 1994. 70 p. Dissertação (Mestrado) - Universidade Federal de Viçosa.

AMARAL SOBRINHO, N.M.B. Interação dos metais pesados de resíduos siderúrgicos com um solo podzólico vermelho amarelo. Viçosa, 1993. 163 p. Tese (Doutorado) - Universidade Federal de Viçosa.

AMRANI, M.; WESTFALL, D.G; PETERSON, G.A. Influence of water solubility of granular zinc fertilizers on plant uptake and growth. Journal of Plant Nutrition v.22, p.1815-1827, 1999. 
ARNON, D.I.; STOUT, P.R. The essentiality of certain elements in minute quantity for plants with special reference to copper. Plant Physiology, v.14, p. 371-375, 1939.

ARNON, I. Mineral nutrition of mayze. Bern: International Potash Institute, 1975. $452 \mathrm{p}$.

BARBOSA FILHO, M.P.; FAGERIA, N.K.; CARVALHO, J.R.P. Fontes de zinco e modos de aplicação sobre a produção de arroz em solos de cerrado. Pesquisa Agropecuária Brasileira, v.17, p.1713-1719, 1982.

BARBOSA FILHO, M.P.; DYNIA, J.F.; ZIMMERMANN, F.J.P Resposta do arroz de sequeiro ao zinco e cobre com efeito residual para o milho. Revista Brasileira de Ciência do Solo, v.14, p.333-338, 1990.

BATAGLIA, O.C.; RAIJ, B. van Eficiência de extratores de micronutrientes na análise de solo. Revista Brasileira de Ciência do Solo, v.13, p.205-212, 1989.

BRASIL, Ministério da Agricultura. Inspeção e fiscalização da produção e do comércio de fertilizantes, corretivos, inoculantes, estimulantes e biofertilizantes destinados à agricultura - Legislação e Fiscalização. Brasília: Secretaria Nacional de Defesa Agropecuária, Divisão de Corretivos e Fertilizantes, 1982. 88 p.

BRASIL, Ministério da Agricultura. Análises de corretivos, fertilizantes e inoculantes - Métodos oficiais. Brasília: Laboratório Nacional de Referência Vegetal (LANARV)/ Secretaria Nacional de Defesa Agropecuária, 1983. 104 p.

BUZETTI, S. Estudo da eficiência de extratores químicos de zinco, no solo, para o milho. Revista Brasileira de Ciência do Solo, v.16, p.367-372, 1992. 
BUZETTI, S.; MURAOKA, T.; SÁ, M.E. Doses de boro na soja, em diferentes condições de acidez do solo: I. Produção de matéria seca e de grãos e nível crítico no solo. Revista Brasileira de Ciência do Solo, v.14, p.157-161, 1990a.

BUZETTI, S.; MURAOKA, T.; SÁ, M.E. Doses de boro na soja, em diferentes condições de acidez do solo: II. Níveis críticos na planta e nos grãos. Revista Brasileira de Ciência do Solo, v.14, p.163-166, 1990 b.

CATANI, R.A.; BERGAMIN FILHO, H. Sobre uma modificação no método de Neubauer. Anais da Escola Superior de Agricultura Luiz de Queiroz, n. 18, p. 287-299, 1961.

COUTINHO, E.L.M.; OTSUBO, A.A.; MARTINS, C.S.; CHILDS, G.F. Resposta do arroz de sequeiro à adubação com zinco. Revista de Agricultura, v.67, p.3-12, 1992a.

COUTINHO, E.L.M.; SITTA, D.S.X.; NATALE, W. Efeitos da calagem e do zinco nas culturas da soja e do milho. In: REUNIÃO BRASILEIRA DE FERTILIDADE DO SOlO E NUTRIÇÃO DE PlANTAS, 20., 1992, Piracicaba. Anais. Piracicaba: Sociedade Brasileira de Ciência do Solo, 1992b. p.322-323.

DECARO, S.T.; VITTI, G.C.; FORNASIERI FILHO, D.; MELO, W.J. Efeito de doses e fontes de zinco na cultura do milho. Revista da Agricultura, v.58, p.25-36, 1983

EMPRESA BRASILEIRA DE PESQUISA AGROPECUÁRIA. Centro Nacional de Pesquisa de Solos. Manual de Métodos de Análise de Solos. 2ed. Rio de Janeiro: EMBRAPA, 1997. 212p. 
GABE, U. Teor e disponibilidade para soja de micronutrientes e elementos potencialmente tóxicos em fertilizantes minerais e calcários. Piracicaba, 1998. 84 p. Tese (Doutorado) - Escola Superior de Agricultura "Luiz de Queiroz".

GALRÃO, E.Z. Níveis críticos de zinco para o milho cultivado em Latossolo VermelhoAmarelo, fase cerrado. Revista Brasileira de Ciência do Solo, Campinas, v.19, p.255-260, 1995.

GOOS, R.J.; JOHNSON, B.E.; THIOLLET, M. A comparasion of the availability of three zinc sources to maize (Zea mays L.) under greenhouse conditions. Biology and Fertility of Soils, v.31, p.343-347, 2000.

JAPÃO. National Institute of Agricultura Sciences - Official methods of analysis of fertilizers. Yatabe-Machi, 1982, $130 \mathrm{p}$.

KANE, P.F. Fertilizers. In: CUNNIFF, P. (Ed.) Official Methods of Analysis, 16 ed. Arlington: AOAC International, 1995. Chapter 2, p. 1-39.

LINDSAY, W.L.; NORVELL, W.A. Development of a DTPA soil test for zinc, iron, manganese, and copper. Soil Science Society of American Journal, v.42, p. 421428, 1978.

LOPES, A.S. Uso eficiente de fertilizantes com micronutrientes. In: SIMPÓSIO SOBRE FERTILIZANTES NA AGRICULTURA BRASILEIRA, 1., Brasília, 1984. Anais. Brasília: EMBRAPA, 1984. p. 347-382.

LOPES, A.S. Micronutrientes: filosofias de aplicação, fontes, eficiência agronômica e preparo de fertilizantes In: FERREIRA, M.E.; CRUZ, M.C.P. Micronutrientes na Agricultura. Piracicaba: Potafós, 1991. p. 357-390. 
MALAVOLTA, E. Elementos de nutrição mineral de plantas. São Paulo: Agronômica Ceres, 1980. 210 p.

MALAVOLTA, E. Manual de química agrícola: adubos e adubação. 3.ed. São Paulo: Agronômica Ceres, 1981. 596 p.

MALAVOLTA, E. Fertilizantes e seu impacto ambiental: micronutrientes e metais pesados, mitos, mistificação e fatos. São Paulo: Produquímica, 1994. 153 p.

MALAVOLTA, E.; PAULINO, V.T.; LOURENÇO, A.J.; MALAVOLTA, M.L.; ALCARDE, J.C.; CORRÊA, J.C.; TERRA, M.M.; CABRAL, C.P. eficiência relativa de fontes de Zn para o milho. Anais da Escola Superior de Agricultura “Luiz de Queiroz", v.44, p.57-76, 1987.

MALAVOLTA, E.; VITTI, G.C.; OLIVEIRA, S.A • Avaliação do estado nutricional das plantas: princípios e aplicações. 2.ed. Piracicaba: Potafós, 1997. 319 p.

MASCARENHAS, H.A.A.; MIRANDA, M.A.C de; BATAGLIA, O.C.; PEREIRA, J.C.V.N.A.; TANAKA, R.T. Deficiência de boro em soja. Bragantia, v.47, p.325$331,1988$.

MOOY, C.J. de; PESEK, J.; SPALDON, E. Mineral nutrition. In: CADWELL, B.E. (Ed.) Soybeans: improvement, production and uses. Madison: American Society of Agronomy, 1973. p. 267-352.

MORTVEDT, J.J. Micronutrient fertilizers and fertilization practices. Fertilizer Research, v.7, p. 221-235, 1985.

MORTVEDT, J.J. Crop response to level of water-soluble zinc in granular zinc fertilizers. Fertilizer Research, v.33, p. 249-255, 1992. 
MORTVEDT, J.J.; CUNNINGHAM, H.G. Production, marketing, and use of other secondary and micronutrient fertilizers. In: OLSON, R.A.; ARMY, T.J.; HANWAY, J.J.; KILMER, V.J. (ed.) Fertilizer technology and use, 2.ed. Madison: Soil Science Society of America, 1971. p.413-454.

NABLE, R.O.; BAÑUElOS, G.S.; PAUlL, J.G. Boron toxicity. Plant and Soil, v.198, p.181-198, 1997.

NIKITIN, A.A. Production and use of trace salts in fertilizers. In: SAUCHELLI, V. (ed.) The chemistry and technology of fertilizers. New York: Reinhold Publ. Corp. 1960. p. 435-445.

OLIVEIRA, J.B. Solos do Estado de São Paulo: descrição das classes registradas no mapa pedológico Campinas: Instituto Agronômico, 1999. 112p. (Boletim Científico 45)

PECK, T.R. Plant analysis for production agriculture. In: SOIL AND PLANT ANALYST'S WORKSHOP, 7., Bridgetown, 1979. Proceedings. Bridgetown, 1979. p.1-45.

RAIJ, B. van. Fertilidade do solo e adubação. Piracicaba: Potafós, 1991a. 343p.

RAIJ, B. van. Geoquímica de micronutrientes. In: FERREIRA, M.E.; CRUZ, M.C.P. Micronutrientes na Agricultura. Piracicaba: Potafós, 1991b. p. 99-111.

RAIJ, B. van; QUAGGIO, J.A. Métodos de análise de solos para fins de fertilidade. Campinas: Instituto Agronômico, 1983. 31p. (Boletim Técnico, 81) 
RITCHEY, K.D.; COX, F.R.; GALRÃO, E.Z.; YOST, R.S. Disponibilidade de zinco para as culturas do milho, sorgo e soja em latossolo vermelho-escuro argiloso. Pesquisa Agropecuária Brasileira, v.21, p.215-225, 1986.

SILVA, A.M.M. da; GRANER, C.A.F. Determinação de boro em fertilizantes pela colorimetria de azometina-H modificada. Eclética Química, v.21, p.61-69, 1996.

SOUZA, E.C.A.; SANTIAGO, G.; OLIVEIRA, L.C.L.; COUTINHO, E.L.M.; LIMA, L.A. Respostas do milho à adubação com fósforo e zinco. Científica, v.13, p.39-49, 1985.

SOUZA, E.C.A.; COUTINHO, E.L.M.; NATALE, W.; BARBOSA, J.C. Respostas do milho a adubação com fósforo e zinco. Pesquisa Agropecuária Brasileira, v.33, p. 1031-1036, 1998.

VALE, F.; ALCARDE, J.C. Solubilidade e disponibilidade dos micronutrientes em fertilizantes. Revista Brasileira de Ciência do Solo, v.23, p.441-451, 1999. 


\section{APÊNDICE}

Tabela 19 - Quadro de análise de variância para o efeito das fontes e doses de boro na produção de matéria seca, em $g$ vaso ${ }^{-1}$, pelas plantas de soja - $1^{0}$ cultivo

\begin{tabular}{lcrrrr}
\hline \multicolumn{1}{c}{ Causas da variação } & G.L. & \multicolumn{1}{c}{ S.Q. } & \multicolumn{1}{c}{ Q.M. } & \multicolumn{1}{c}{ Valor F } & Prob.> F \\
\hline Fertilizantes & 5 & 5,5233 & 1,1046 & 1,6229 & 0,17130 \\
Doses & 3 & 312,6903 & 104,2301 & 153,1231 & 0,00001 \\
Fertilizantes x doses & 15 & 7,7366 & 0,5157 & 0,7577 & 0,71554 \\
Resíduo & 48 & 32,6733 & 0,6806 & & \\
\hline Total & 71 & 358,6236 & & & \\
\hline
\end{tabular}

Tabela 20 - Quadro de análise de variância para o efeito das fontes e doses de boro no teor de boro, em $\mathrm{mg} \mathrm{kg}^{-1}$, encontrado nas plantas de soja - $1^{\circ}$ cultivo

\begin{tabular}{lcrrrr}
\hline \multicolumn{1}{c}{ Causas da variação } & G.L. & \multicolumn{1}{c}{ S.Q. } & \multicolumn{1}{c}{ Q.M. } & \multicolumn{1}{c}{ Valor F } & Prob.> F \\
\hline Fertilizantes & 5 & 4632,1075 & 926,4215 & 1,9913 & 0,09623 \\
Doses & 3 & 236165,6527 & 78721,8842 & 169,2061 & 0,00001 \\
Fertilizantes x doses & 15 & 5346,7791 & 356,4519 & 0,7662 & 0,70702 \\
Resíduo & 48 & 22331,6439 & 465,2425 & & \\
\hline Total & 71 & 268476,1834 & & & \\
\hline
\end{tabular}

Tabela 21 - Quadro de análise de variância para o efeito das fontes e doses de boro no conteúdo de boro, em mg, nas plantas de soja $-1^{\underline{o}}$ cultivo

\begin{tabular}{lccccc}
\hline \multicolumn{1}{c}{ Causas da variação } & G.L. & S.Q. & Q.M. & Valor F & Prob.> F \\
\hline Fertilizantes & 5 & 0,0439 & 0,0088 & 0,2724 & 0,92521 \\
Doses & 3 & 9,6134 & 3,2045 & 99,3956 & 0,00001 \\
Fertilizantes x doses & 15 & 0,0674 & 0,0045 & 0,1395 & 0,99979 \\
Resíduo & 48 & 1,5475 & 0,0322 & & \\
\hline Total & 71 & 11,2723 & & & \\
\hline
\end{tabular}


Tabela 22 - Quadro de análise de variância para o efeito das fontes e doses de boro no teor de boro residual no solo, em $\mathrm{mg} \mathrm{dm}^{-3}$, solúvel em solução de cloreto de bário a quente

\begin{tabular}{lcccrr}
\hline \multicolumn{1}{c}{ Causas da variação } & G.L. & \multicolumn{1}{c}{ S.Q. } & Q.M. & Valor F & Prob.> F \\
\hline Fertilizantes & 5 & 0,0556 & 0,0111 & 1,4861 & 0,21116 \\
Doses & 3 & 12,6832 & 4,2277 & 564,7464 & 0,00001 \\
Fertilizantes x doses & 15 & 0,0931 & 0,0062 & 0,8293 & 0,64213 \\
Resíduo & 48 & 0,3593 & 0,0075 & & \\
\hline Total & 71 & 13,1913 & & & \\
\hline
\end{tabular}

Tabela 23 - Quadro de análise de variância para o efeito das fontes e doses de boro na produção de matéria seca, em $\mathrm{g}$ vaso $^{-1}$, pelas plantas de soja $-2^{\underline{0}}$ corte

\begin{tabular}{lcrrrr}
\hline \multicolumn{1}{c}{ Causas da variação } & G.L. & \multicolumn{1}{c}{ S.Q. } & \multicolumn{1}{c}{ Q.M. } & \multicolumn{1}{c}{ Valor F } & Prob.> F \\
\hline Fertilizantes & 5 & 2,0614 & 0,4122 & 0,4725 & 0,79645 \\
Doses & 3 & 371,6526 & 123,8842 & 141,9862 & 0,00001 \\
Fertilizantes x doses & 15 & 14,5985 & 0,9732 & 1,1154 & 0,36878 \\
Resíduo & 48 & 41,8804 & 0,8725 & & \\
\hline Total & 71 & 430,1929 & & & \\
\hline
\end{tabular}

Tabela 24 - Quadro de análise de variância para o efeito residual das fontes e doses de boro no teor de boro, em $\mathrm{mg} \mathrm{kg}^{-1}$, encontrado nas plantas de soja $-2^{\mathrm{o}}$ cultivo

\begin{tabular}{lcrrrr}
\hline \multicolumn{1}{c}{ Causas da variação } & G.L. & \multicolumn{1}{c}{ S.Q. } & \multicolumn{1}{c}{ Q.M. } & Valor F & Prob. $>$ F \\
\hline Fertilizantes & 5 & 3497,9390 & 699,5878 & 2,8303 & 0,02525 \\
Doses & 3 & 29675,0586 & 9891,6862 & 40,0188 & 0,00001 \\
Fertilizantes x doses & 15 & 6921,0871 & 461,4058 & 1,8667 & 0,05170 \\
Resíduo & 48 & 11864,4346 & 247,1757 & & \\
\hline Total & 71 & 51958,5194 & & & \\
\hline
\end{tabular}


Tabela 25 - Quadro de análise de variância para o efeito residual das fontes e doses de boro no conteúdo de boro, em $\mathrm{mg}$, nas plantas de soja $-2^{\underline{o}}$ cultivo

\begin{tabular}{lcccrr}
\hline \multicolumn{1}{c}{ Causas da variação } & G.L. & S.Q. & Q.M. & Valor F & Prob.> F \\
\hline Fertilizantes & 5 & 0,1889 & 0,0378 & 2,6638 & 0,03288 \\
Doses & 3 & 4,0633 & 1,3544 & 95,4908 & 0,00001 \\
Fertilizantes x doses & 15 & 0,3741 & 0,0249 & 1,7586 & 0,07035 \\
Resíduo & 48 & 0,6808 & 0,0141 & & \\
\hline Total & 71 & 5,3072 & & & \\
\hline
\end{tabular}

Tabela 26 - Quadro de análise de variância para o efeito das fontes e doses de zinco na produção de matéria seca, em g vaso ${ }^{-1}$, pelas plantas de arroz - $1^{0}$ cultivo

\begin{tabular}{lccccc}
\hline \multicolumn{1}{c}{ Causas da variação } & G.L. & \multicolumn{1}{c}{ S.Q. } & Q.M. & Valor F & Prob.> F \\
\hline Fertilizantes & 5 & 2,5308 & 0,5062 & 0,8345 & 0,53309 \\
Doses & 3 & 12,7815 & 4,2605 & 7,0245 & 0,00077 \\
Fertilizantes x doses & 15 & 8,6933 & 0,5796 & 0,9555 & 0,51361 \\
Resíduo & 48 & 29,1129 & 0,6065 & & \\
\hline Total & 71 & 53,1186 & & & \\
\hline
\end{tabular}

Tabela 27 - Quadro de análise de variância para o efeito das fontes e doses de zinco no teor do elemento, em $\mathrm{mg} \mathrm{kg}^{-1}$, nas plantas de arroz $-1^{\mathrm{o}}$ cultivo

\begin{tabular}{lccrrr}
\hline \multicolumn{1}{c}{ Causas da variação } & G.L. & \multicolumn{1}{c}{ S.Q. } & \multicolumn{1}{c}{ Q.M. } & Valor F & Prob.> F \\
\hline Fertilizantes & 5 & 240,4389 & 48,0877 & 9,9087 & 0,00002 \\
Doses & 3 & 860,0412 & 286,6804 & 59,0721 & 0,00001 \\
Fertilizantes x doses & 15 & 227,2928 & 15,1528 & 3,1223 & 0,00163 \\
Resíduo & 48 & 232,9469 & 4,8531 & & \\
\hline Total & 71 & 1560,7199 & & & \\
\hline
\end{tabular}


Tabela 28 - Quadro de análise de variância para o efeito das fontes e doses de zinco no conteúdo do elemento, em mg, nas plantas de arroz - $1^{0}$ cultivo

\begin{tabular}{lcccrr}
\hline \multicolumn{1}{c}{ Causas da variação } & G.L. & S.Q. & Q.M. & Valor F & Prob.> F \\
\hline Fertilizantes & 5 & 0,0237 & 0,0047 & 8,3671 & 0,00005 \\
Doses & 3 & 0,0935 & 0,0311 & 55,0176 & 0,00001 \\
Fertilizantes x doses & 15 & 0,0195 & 0,0013 & 2,2985 & 0,01487 \\
Resíduo & 48 & 0,0272 & 0,0006 & & \\
\hline Total & 71 & 0,1639 & & & \\
\hline
\end{tabular}

Tabela 29 - Quadro de análise de variância para o efeito das fontes e doses de zinco no teor de zinco residual no solo, em $\mathrm{mg} \mathrm{dm}^{-3}$, solúvel em solução de DTPA arroz

\begin{tabular}{lcccrr}
\hline \multicolumn{1}{c}{ Causas da variação } & G.L. & S.Q. & Q.M. & Valor F & Prob.> F \\
\hline Fertilizantes & 5 & 0,8285 & 0,1657 & 52,5352 & 0,00001 \\
Doses & 3 & 7,0976 & 2,3659 & 750,0819 & 0,00001 \\
Fertilizantes x doses & 15 & 0,4270 & 0,0285 & 9,0264 & 0,00001 \\
Resíduo & 48 & 0,1514 & 0,0031 & & \\
\hline Total & 71 & 8,5046 & & & \\
\hline
\end{tabular}

Tabela 30 - Quadro de análise de variância para o efeito residual das fontes e doses de zinco na produção de matéria seca, em $\mathrm{g}$ vaso $^{-1}$, pelas plantas de arroz $-2^{\mathrm{o}}$ cultivo

\begin{tabular}{lcrrrr}
\hline \multicolumn{1}{c}{ Causas da variação } & G.L. & \multicolumn{1}{c}{ S.Q. } & \multicolumn{1}{c}{ Q.M. } & \multicolumn{1}{c}{ Valor F } & Prob.> F \\
\hline Fertilizantes & 5 & 6,1751 & 1,2350 & 4,4029 & 0,00253 \\
Doses & 3 & 137,7048 & 45,9016 & 163,6415 & 0,00001 \\
Fertilizantes x doses & 15 & $5,0,125$ & 0,3342 & 1,1913 & 0,31015 \\
Resíduo & 48 & 13,4640 & 0,2805 & & \\
\hline Total & 71 & 162,3565 & & & \\
\hline
\end{tabular}


Tabela 31 - Quadro de análise de variância para o efeito residual das fontes e doses de zinco no teor do elemento, em $\mathrm{mg} \mathrm{kg}^{-1}$, encontrado nas plantas de arroz $-2^{\mathrm{o}}$ cultivo

\begin{tabular}{lccrrr}
\hline \multicolumn{1}{c}{ Causas da variação } & G.L. & S.Q. & \multicolumn{1}{c}{ Q.M. } & Valor F & Prob.> F \\
\hline Fertilizantes & 5 & 113,2348 & 2,6469 & 3,1903 & 0,01441 \\
Doses & 3 & 351,1537 & 117,0512 & 16,4893 & 0,00001 \\
Fertilizantes x doses & 15 & 143,6096 & 9,5740 & 1,3487 & 0,21169 \\
Resíduo & 48 & 340,7330 & 7,0986 & & \\
\hline Total & 71 & 948,7311 & & & \\
\hline
\end{tabular}

Tabela 32 - Quadro de análise de variância para o efeito residual das fontes e doses de zinco no conteúdo do elemento, em $\mathrm{mg}$, nas plantas de arroz $-2^{\underline{o}}$ cultivo

\begin{tabular}{lcccrr}
\hline \multicolumn{1}{c}{ Causas da variação } & G.L. & S.Q. & Q.M. & Valor F & Prob.> F \\
\hline Fertilizantes & 5 & 0,0118 & 0,0023 & 11,2482 & 0,00001 \\
Doses & 3 & 0,0796 & 0,0265 & 126,6371 & 0,00001 \\
Fertilizantes x doses & 15 & 0,0083 & 0,0005 & 2,6296 & 0,00587 \\
Resíduo & 48 & 0,0100 & 0,0002 & & \\
\hline Total & 71 & 0,1097 & & & \\
\hline
\end{tabular}

Tabela 33 - Quadro de análise de variância para o efeito das fontes e doses de zinco na produção de matéria seca, em $\mathrm{g}$ vaso ${ }^{-1}$, pelas plantas de milho - $1^{\circ}$ cultivo

\begin{tabular}{lcrrrr}
\hline \multicolumn{1}{c}{ Causas da variação } & G.L. & \multicolumn{1}{c}{ S.Q. } & \multicolumn{1}{c}{ Q.M. } & \multicolumn{1}{c}{ Valor F } & Prob.> F \\
\hline Fertilizantes & 5 & 453,8861 & 90,7772 & 13,2978 & 0,00001 \\
Doses & 3 & 2679,1527 & 893,0509 & 130,8217 & 0,00001 \\
Fertilizantes x doses & 15 & 186,9363 & 12,4624 & 1,8256 & 0,05815 \\
Resíduo & 48 & 327,6707 & 6,8265 & & \\
\hline Total & 71 & 3647,6457 & & & \\
\hline
\end{tabular}


Tabela 34 - Quadro de análise de variância para o efeito das fontes e doses de zinco no teor do elemento, em $\mathrm{mg} \mathrm{kg}^{-1}$, nas plantas de milho - $1^{\circ}$ cultivo

\begin{tabular}{lccccc}
\hline \multicolumn{1}{c}{ Causas da variação } & G.L. & \multicolumn{1}{c}{ S.Q. } & Q.M. & Valor F & Prob.> F \\
\hline Fertilizantes & 5 & 7,5546 & 1,5109 & 0,7479 & 0,59356 \\
Doses & 3 & 28,3804 & 9,4601 & 4,6829 & 0,00623 \\
Fertilizantes x doses & 15 & 20,8770 & 1,3918 & 0,6890 & 0,78267 \\
Resíduo & 48 & 96,9666 & 2,0201 & & \\
\hline Total & 71 & 153,7787 & & & \\
\hline
\end{tabular}

Tabela 35 - Quadro de análise de variância para o efeito das fontes e doses de zinco no conteúdo do elemento, em mg, pelas plantas de milho $-1^{1^{\circ}}$ cultivo

\begin{tabular}{lcccrr}
\hline \multicolumn{1}{c}{ Causas da variação } & G.L. & S.Q. & Q.M. & Valor F & Prob. $>$ F \\
\hline Fertilizantes & 5 & 0,0477 & 0,0095 & 10,3058 & 0,00001 \\
Doses & 3 & 0,1969 & 0,0656 & 7,8471 & 0,00001 \\
Fertilizantes x doses & 15 & 0,2041 & 0,0016 & 1,7322 & 0,07578 \\
Resíduo & 48 & 0,0444 & 0,0009 & & \\
\hline Total & 71 & 0,3131 & & & \\
\hline
\end{tabular}

Tabela 36 - Quadro de análise de variância para o efeito das fontes e doses de zinco no teor de zinco residual no solo, em $\mathrm{mg} \mathrm{dm}^{-3}$, solúvel em solução de DTPA milho

\begin{tabular}{lccccc}
\hline \multicolumn{1}{c}{ Causas da variação } & G.L. & S.Q. & Q.M. & Valor F & Prob.> F \\
\hline Fertilizantes & 5 & 2,3975 & 0,4795 & 45,6976 & 0,00001 \\
Doses & 3 & 21,5195 & 7,1731 & 683,6125 & 0,00001 \\
Fertilizantes x doses & 15 & 1,7082 & 0,1139 & 10,8528 & 0,00001 \\
Resíduo & 48 & 0,5036 & 0,0105 & & \\
\hline Total & 71 & 26,1289 & & & \\
\hline
\end{tabular}


Tabela 37 - Quadro de análise de variância para o efeito residual das fontes e doses de zinco na produção de matéria seca, em $g$ vaso ${ }^{-1}$, pelas plantas de milho $-2^{\mathrm{o}}$ cultivo

\begin{tabular}{lcrrrr}
\hline \multicolumn{1}{c}{ Causas da variação } & G.L. & \multicolumn{1}{c}{ S.Q. } & \multicolumn{1}{c}{ Q.M. } & Valor F & Prob.> F \\
\hline Fertilizantes & 5 & 24,5292 & 4,9058 & 1,3163 & 0,27241 \\
Doses & 3 & 713,7015 & 237,9005 & 63,8293 & 0,00001 \\
Fertilizantes x doses & 15 & 16,8988 & 1,1266 & 0,3023 & 0,99256 \\
Resíduo & 48 & 178,9026 & 3,7271 & & \\
\hline Total & 71 & 934,0322 & & & \\
\hline
\end{tabular}

Tabela 38 - Quadro de análise de variância para o efeito das fontes e doses de zinco no teor do elemento, em $\mathrm{g} \mathrm{kg}^{-1}$, pelas plantas de milho $-2^{\underline{o}}$ cultivo

\begin{tabular}{lcrrrr}
\hline \multicolumn{1}{c}{ Causas da variação } & G.L. & \multicolumn{1}{c}{ S.Q. } & Q.M. & Valor F & Prob.> F \\
\hline Fertilizantes & 5 & 42,1861 & 8,4372 & 7,6403 & 0,00008 \\
Doses & 3 & 243,8072 & 81,2691 & 73,5930 & 0,00001 \\
Fertilizantes x doses & 15 & 39,0260 & 2,6017 & 2,3560 & 0,01262 \\
Resíduo & 48 & 53,0066 & 1,1043 & & \\
\hline Total & 71 & 378,0261 & & & \\
\hline
\end{tabular}

Tabela 39 - Quadro de análise de variância para o efeito das fontes e doses de zinco no conteúdo de elemento, em $\mathrm{mg}$, nas plantas de milho $-2^{\underline{0}}$ cultivo

\begin{tabular}{lcccrr}
\hline \multicolumn{1}{c}{ Causas da variação } & G.L. & S.Q. & Q.M. & Valor F & Prob. $>$ F \\
\hline Fertilizantes & 5 & 0,0912 & 0,0182 & 9,0580 & 0,00003 \\
Doses & 3 & 0,7669 & 0,2556 & 126,8949 & 0,00001 \\
Fertilizantes x doses & 15 & 0,0733 & 0,0049 & 2,4284 & 0,01028 \\
Resíduo & 48 & 0,0966 & 0,0020 & & \\
\hline Total & 71 & 1,0281 & & & \\
\hline
\end{tabular}

